\title{
THE HUMAN RIGHTS OBLIGATIONS OF THE HOLY SEE UNDER THE CONVENTION ON THE RIGHTS OF THE CHILD
}

\author{
WILLIAM THOMAS WORSTER*
}

This article analyzes how human rights obligations apply to the Holy See, focusing on the Convention on the Rights of the Child (CRC) as the case study. The Holy See is the sovereign of a state and yet it is also a unique nonstate actor in international law. Unlike other non-state actors, it has international legal personality, controls territory, and is party to several human rights treaties. At the same time, the Holy See is also a religious institution whose governance of a church is not subject to international law. This unusual arrangement challenges the application of human rights treaties whose terms were designed with territorial states in mind.

Under human rights treaties, including the CRC, states parties are only responsible for wrongful acts that are attributable to them, and occur within their jurisdiction. In order to violate the CRC, consequently, a state must not only act wrongfully, but it must have done so in a situation in which it has a sufficient degree of control. However, the Holy See is non-territorial entity that governs a micro-state as one of its international roles, and this reality challenges the application of the jurisdictional requirement. Although the Holy See is bound, it is unclear when its obligations arise.

This article concludes that human rights obligations, such as the CRC, should apply to the Holy See similarly to the current approach applied to states. The first critical issue in assessing the applicability of the CRC to the Holy See is describing the relationship between the Holy See and the Vatican City, as two distinct international legal persons, and identifying which entity is party to the CRC. The second issue is applying the concept of jurisdiction as provided in the CRC and in keeping with other human rights treaties, being de facto control, to this non-territorial entity that governs a territorial state. This analysis shows that the Holy See is indeed bound by the CRC and subject to its obligations where it has sufficient control.

Copyright $\odot 2021$ William Thomas Worster

* Senior Lecturer, International Law, The Hague University of Applied Sciences, The Hague, The Netherlands; Ph.D. candidate, International Law, University of Amsterdam; LL.M. (Adv.) in Public International Law, cum laude, Leiden University; J.D., Chicago-Kent College of Law, Illinois Institute of Technology. 
This article has immediate significance for two reasons. Firstly, this article supports the numerous claims against the Holy See of child abuse as violations of the CRC. Secondly, it also demonstrates that this unusual nonstate actor can acquire and comply with human rights obligations. In turn, confirming that human rights obligations apply to this unique actor informs the international community that, following the existing framework, human rights obligations could potentially apply to other non-state actors as international law continues to evolve.

I. INTRODUCTION 352

II. THE HOLY SEE AS THE PARTY TO THE CRC 354

A. Defining the Holy See and its Role in International Law................. 355

1. The Holy See as an International Legal Person ........................... 357

2. The Holy See's Engagement on the International Plane............. 360

3. The Holy See's Moral and Political Role ................................. 365

B. The Distinction Between the Holy See and the Vatican City State.. 369

1. Two Distinct International Legal Persons................................. 369

2. The Holy See is the Sovereign of the Vatican City ................... 374

C. The Holy See is the Party the CRC, Not the Vatican City ............... 377

1. Separate Treaty Adherence by the Holy See and Vatican City.. 377

2. Evidence of the Holy See as the Party to the CRC ................... 384

III. THE JURISDICTION OF THE HOLY SEE ................................................. 389

A. Territorial Jurisdiction in Human Rights Law.................................... 396

B. Extraterritorial Jurisdiction in Human Rights Law ......................... 399

1. Jurisdiction When a State Affects Human Rights Abroad......... 399

2. Jurisdiction When Acts Create Effects Abroad ......................... 400

3. Jurisdiction When Acts are Undertaken Outside of the State .... 402

a. Jurisdiction Based on Control over Territory ..................... 403

b. Jurisdiction Based on Control over Persons ........................ 408

i. Attribution of the Acts of State Officials..................... 408

ii. Attribution of the Acts of Non-Officials of the State .. 411

iii. Jurisdiction Based on Physical Control over the

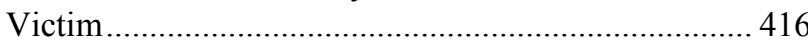

iv. Jurisdiction Based on Non-Physical Control over the Victim

\section{INTRODUCTION}

In considering whether human rights law applies to non-state actors, we should examine a non-state actor that is quite clearly bound to human rights law: the case of the Holy See and its adherence to the Convention on the 
Rights of the Child (CRC). ${ }^{1}$ While many have debated whether non-state actors can be held responsible for human rights obligations, most analyses omit the unique case of the Holy See. ${ }^{2}$ It is very unusual for a religious institution to participate in international law, and the Holy See sometimes resists the "normal" application of international law to its activities, citing its unique nature. It does seem strange to subject a church to international law. However, the Holy See was an enthusiastic participant in the negotiations over the $\mathrm{CRC}$, ensuring that there was an international treaty specifically devoted to the human rights specifically enjoyed by children and later helping it become one of the most widely applicable human rights instruments in the world. ${ }^{3}$ As a party to the treaty, the Holy See is undoubtedly bound just like any other party. However, the question in this article is whether the human rights obligations in the CRC can apply to the Holy See, as a non-state actor, in the same or similar manner as they apply to states.

Since the Holy See has only adhered to a small number of human rights treaties, this article will study this question by using a case study. Specifically, the case study is the view of the Committee on the Rights of the Child (CommRC) - that the Holy See was responsible for violations of the rights of children during the child abuse scandals of the last many years. In 2014, the CommRC released its second periodic report of the Holy See on its compliance with the CRC. ${ }^{4}$ The Committee not only affirmed the obligation of the Holy See to uphold the rights of the child within the territory of the Vatican City, but also demanded that the Holy See ensure the rights of

1. See Convention on the Rights of the Child, opened for signature Nov. 20, 1989, 1577 U.N.T.S. 3 (entered into force Sept. 2, 1990) [hereinafter Convention on the Rights of the Child].

2. See, e.g., Andrew Clapham, Human Rights Obligations of Non-State Actors 59, 189 (2006) (mentioning the Holy See in the context of human rights law without analyzing its responsibility regarding enforcement of human rights obligations). Some analyses instead focus on the responsibility of states for human rights when those states engage with the Holy See, rather than the obligations of the Holy See itself. See, e.g., Pellegrini v. Italy, 2001-VIII Eur. Ct. H.R. 369, para. 40 ("The Court notes at the outset that the applicant's marriage was annulled by a decision of the Vatican courts which was declared enforceable by the Italian courts. The Vatican has not ratified the Convention and, furthermore, the application was lodged against Italy. The Court's task therefore consists not in examining whether the proceedings before the ecclesiastical courts complied with Article 6 of the Convention, but whether the Italian courts, before authorising enforcement of the decision annulling the marriage, duly satisfied themselves that the relevant proceedings fulfilled the guarantees of Article 6.").

3. Status of the Convention on the Rights of the Child, UNITED NATIONS TREATY COLLECTION [hereinafter Status of the CRC], https://treaties.un.org/Pages/ViewDetails.aspx?src=TREATY \&mtdsg no=IV-11\&chapter=4\&clang=_en [https://perma.cc/CRG7-LGBD] (last visited Feb. 27, 2021).

4. See U.N., Comm. on the Rights of the Child, Concluding Observations on the Second Periodic Report of the Holy See, I 8, U.N. Doc. CRC/C/VAT/CO/2 (Feb. 25, 2014) [hereinafter Concluding Observations of the Second Periodic Report]. 
the child in the practices of the Catholic Church worldwide. ${ }^{5}$ It held that the Holy See "in ratifying the Convention, it made a commitment to implement it not only within the territory of Vatican City State, but also, as the supreme power of the Catholic Church, worldwide through individuals and institutions under its authority." "The CommRC justified this interpretation of the application of the CRC by reference to Canons 331 and 590. ${ }^{7}$ These provisions of ecclesiastical law bind subordinates (bishops, major superiors of religious institutes, etc.) to obedience to the Pope. In the view of the CommRC, those provisions demonstrated that the Holy See exercises sufficient jurisdiction to render it responsible for child abuse committed by those subordinates. The Holy See rejected this view.

This article steps into this disagreement between the CommRC and the Holy See that remains unresolved. It examines whether and how this unique actor exercises jurisdiction within the meaning of the $\mathrm{CRC}$, in light of the development of human rights jurisprudence. Even though the Holy See is an unusual case, this article will suggest that human rights norms could apply to other non-state actors using the existing legal framework. These other nonstate actors could include international organizations, but also perhaps armed non-state actors, corporations, non-governmental organizations or hybrid public-private partnerships. After all, the existing legal framework has accommodated the Holy See's adherence to the CRC without needing to prescribe special terms for its participation and without any objection by states.

As international law develops, the international community may extend human rights obligations to a variety of groups, so the approach in this article may be helpful to understood how those norms could potentially apply. However, because the Holy See is a non-state actor that can already be held to these norms, it is helpful to examine its participation in the CRC as a case study. This article will therefore focus on the Holy See as a unique non-state actor, bearing the same human rights obligations as states.

\section{THE HOLY SEE AS THE PARTY TO THE CRC}

Before examining the scope of the Holy See's legal obligations, it is necessary to consider the particular nature of the Holy See and its adherence to the CRC. As will be discussed below, the Holy See and Vatican City are distinct entities, so identifying the precise party to the $\mathrm{CRC}$ is critical. In addition, while the Vatican City is a state, the Holy See is a non-territorial,
5. See id.
6. Id.
7. Id. 
non-state international legal person which could raise doubts about its ability to comply with human rights obligations. In order to identify the party, the scope of international legal obligations, and the ability to discharge those legal obligations, this section begins by defining the Holy See and its participation in international relations.

\section{A. Defining the Holy See and its Role in International Law}

The Holy See is a very unusual case in international law, ${ }^{8}$ so this first section will clarify its precise nature and the way that it participates in international relations. The definition of the Holy See is not completely clear, as the entity itself acknowledges. ${ }^{9}$ Under its own governing law, it can be defined narrowly or broadly. ${ }^{10}$ The narrower definition of the Holy See only includes the office of the Pope, ${ }^{11}$ and possibly any offices exercised authority delegated to it by the Pope. ${ }^{12}$ The narrow argument suggests that if the entire governance of the Holy See was reduced to only the papal office, the Holy See would continue to retain its legal personality. ${ }^{13}$ Certainly, it does encompass the Pope. ${ }^{14}$ However, the Holy See cannot be synonymous with the Pope as an individual in a personal or official capacity. When a pope dies, the See, much like the crown of a monarchy, continues; the College of Cardinals governs until a new pope is elected. If the Pope was the Holy See,

8. See Holy See v. Starbright Sales Enters., Inc., 102 I.L.R. 163, 169 (S.C., Dec. 1, 1994) (Phil.) ("The Vatican City fits into none of the established categories of States, and the attribution to it of 'sovereignty' must be made in a sense different from that in which it is applied to other States.").

9. See U.N., Comm. on the Rights of the Child, List of Issues in Relation to the Second Periodic Report of the Holy See, Addendum: Replies of the Holy See to the List of Issues, U.N. Doc. CRC/C/VAT/Q/2/Add.1 (Jan. 9, 2014) [hereinafter List of Issues in Relation to the Second Periodic Report]; cf. The Lateran Treaty, It.-Vatican, art. 3, Feb. 11, 1929, reprinted in 23 AM. J. INT'L L. 187 (1929) [hereinafter Lateran Accords] ("Italy recognizes the full possession and exclusive and absolute power and sovereign jurisdiction of the Holy See over the Vatican ....”). These provisions demonstrate that even in the Lateran Accords, which establish the foundational arrangement between Italy and the Holy See, there is confusion as to whether the Pope is the sovereign over the Vatican City or whether it is the Holy See that is sovereign, or whether the Pope is the Holy See. See id. art. 26 ("Italy, in turn, recognizes the State of the Vatican under the sovereignty of the Supreme Pontiff.").

10. See Lateran Accords, supra note 9.

11. See Starbright Sales, 102 I.L.R. at 168-69. In international practice, there was at least one treaty that was adopted in the name of the Pope rather than the Holy See, though this may be a mistranslation or anachronism. Agreement Between Hanover and the Pope, Hanover-Pope Leo XII, at 111, March 26, 1824, 74 Consol. T.S. 111.

12. See Doe v. Holy See, 557 F.3d 1066, 1070 (9th Cir. 2009); Melanie Black, The Unusual Sovereign State: The Foreign Sovereign Immunities Act and Litigation Against the Holy See for Its Role in the Global Priest Sexual Abuse Scandal, 27 Wis. INT'L L.J. 299 (2009).

13. See Archbishop Jean-Louis Pierre Tauran, Holy See Secretariat of State, Lecture at Catholic University of the Sacred Heart, Milan: The Presence of the Holy See in the International Organizations (Apr. 22, 2002) [hereinafter Tauran's Lecture].

14. See Starbright Sales, 102 I.L.R. at 168 ("Before the annexation of the Papal States by Italy in 1870, the Pope was the monarch and, as The Holy See, was considered a subject of international law."). 
then the College could not govern unless it assumed the papal office. On this basis, some scholars define the Holy See more broadly to include the College of Cardinals, ${ }^{15}$ and other authorities go even further to include the central governance organs of the Catholic Church. ${ }^{16}$

As for the views of the Holy See itself, it prescribes its own definition. Under Canon Law, the Holy See is the Pope and church institutions that derive from the office such as the Secretary of State. ${ }^{17}$ More specifically, the Holy See states that the term "Holy See refers not only to the Roman Pontiff but also to the Secretariat of State, the Council for the Public Affairs of the Church, and other institutes of the Roman Curia . ..."18 The Curia is the central administration of the Holy See and is usually defined as "the Secretariat of State or the Papal Secretariat, the Council for the Public Affairs of the Church, congregations, tribunals, and other institutes." ${ }^{19}$ However, the Holy See does sometimes simply use the more vague definition that it is the "highest organ of government of the Catholic Church" 20 or the "Sovereign

15. See Hyginus Eugene Cardinale, The Holy See and the International Order 85 (1976).

16. See James R. Crawford, The Creation of States in International LaW 225-26 (2d ed. 2007); Robert A. Graham, Vatican Diplomacy: A Study of Church and State on the International Plane 157-83 (1959); Cedric Ryngaert, The Legal Status of the Holy See, 3 GoetTingen J. InT'L L. 829 (2011); List of Issues in Relation to the Second Periodic Report, supra note 9; U.N., Comm. on the Rights of the Child, Consideration of Reports Submitted by States Parties Under Article 44 of the Convention, Second Reports of States Parties Due in 1997: Holy See, U.N. Doc. CRC/C/VAT/2 (Oct. 22, 2012) [hereinafter Second Reports of States Parties Due in 1997]; U.N., Comm. on the Rights of the Child, Consideration of Reports Submitted by States Parties under Article 44 of the Convention, Initial Reports of States Parties Due in 1992: Holy See, U.N. Doc. CRC/C/3/Add.27 (Mar. $28,1994)$ [hereinafter Initial Reports of States Parties Due in 1992].

17. See U.N., Comm. on the Elimination of Racial Discrimination, Consideration of Reports Submitted by States Parties Under Article 9 of the Convention, Sixteenth to Twenty-Third Periodic Reports of States Parties Due in 2014: Holy See, ๆ 7, U.N. Doc. CERD/C/VAT/16-23 (Sept. 4, 2014) [hereinafter CERD, Consideration of Reports 2014] ("According to the internal law of the Catholic Church the term Holy See 'refers not only to the Roman Pontiff but also to the Secretariat of State, the Council for Public Affairs of the Church, and other institutes of the Roman Curia, unless it is otherwise apparent from the nature of the matter or the context of the words ....'") (citations omitted). List of Issues in Relation to the Second Periodic Report, supra note 9, 9 ("The Holy See intended as the Roman Pontiff, in the narrow sense, and the Roman Pontiff with his dicasteries (especially the Secretariat of State) in the broader sense ...."); cf. Town Invs. Ltd. v. Dep't of the Env't [1978] 359 AC (HL) 380-81 (appeal taken from Eng.) (explaining how the label "the Crown" in the United Kingdom is variously understood as a reference to either the sovereign individually, the Government, or the bureaucracy responsible for carrying out the government's ministerial duties).

18. 1983 CODE c.361.

19. Id. c. 360 .

20. Initial Reports of States Parties Due in 1992, supra note 16, $\uparrow 1$; CARDINALE, supra note 15. 
Authority of the Catholic Church," 21 with the Pope being the Head of that organ or authority. ${ }^{22}$

Following from these various definitions, the better interpretation is that the Holy See is not the Pope, but rather an entity that includes the office of the Pope, the College of Cardinals and other bodies as its organs or offices.

\section{The Holy See as an International Legal Person}

Having identified the definition of the Holy See, the next question is how it participates in international relations. Under international law, the Holy See is regarded as an international legal person ${ }^{23}$ meaning that it is capable of bearing international rights and obligations. ${ }^{24}$ Although no serious authorities deny that it has international legal personality, it is also clearly not a state. ${ }^{25}$ It cannot be a state because it is separate and distinct from the Vatican City and has no territory, ${ }^{26}$ despite it being sometimes incorrectly characterized as a state. ${ }^{27}$ The Holy See, in this view, is not only a church or

21. Basic Agreement Between the Holy See and the Palestine Liberation Organization, Palestine Liberation Org.-Vatican, Feb. 15, 2000, 92 Acta Apost. Sedis 853.

22. 1983 CODE c.331.

23. See CERD, Consideration of Reports 2014, supra note 17, ๆ 12 ("The Holy See is a sovereign and unique subject of international law having an original, non-derived legal personality independent of any authority or jurisdiction, which exercises its sovereignty over the territory of VCS [Vatican City State].”); U.N., Comm. on the Elimination of Racial Discrimination, Consideration of Reports Submitted by States Parties Under Article 9 of the Convention, Fifteenth Periodic Reports of States Parties Due in 1998: Holy See, I 4(a), U.N. Doc. CERD/C/338/Add.11 (May 26, 2000) [hereinafter CERD, Consideration of Reports 2000]; CRAWFORD, supra note 16, at 157; 1 LASSA OPPENHEIM, INTERNATIONAL LAW: A TREATISE 160 (2d ed. 1912) (taking the more nuanced view that the Holy See is treated as an international legal person with the Pope as its monarch, even though this is not technically correct); Josef L. Kunz, The Status of the Holy See in International Law, 46 AM. J. INT'L L. 308, 313 (1952); John R. Morss, The International Legal Status of the Vatican/Holy See Complex, 26 EUR. J. INT'L L. 927,929 (2015).

24. See Reparation for Injuries Suffered in the Service of the United Nations, Advisory Opinion, 1949 I.C.J. 174, 178-79 (Apr. 11).

25. See CRAWFORD, supra note 16, at 43-44; JORRI DUURSMA, FrAGMENTATION AND THE INTERNATIONAL RELATIONS OF MiCRO-STATES 374-419 (1996). The Holy See is also often treated simply as a church under international law. See, e.g., Albert-Engelmann-Gesellschaft MBH v. Austria, App. No. 46389/99, para. 32 (Eur. Ct. H.R., 2006), http://hudoc.echr.coe.int/eng?i=001-72090 [https://perma.cc/ZU99-FCUS] ("The Court note[d] ... . Mr Paarhammer ... publicly criticised and disparaged the Pope in an extremely offensive manner ... . [and that] Mr Paarhammer had previously publicly uttered criticism against the Holy See. . . [but that such statements fall under] freedom of the press ... ."); Ryngaert, supra note 16; Yasmin Abdullah, Note, The Holy See at United Nations Conferences: State or Church?, 96 COlum. L. REV. 1835, 1835-37 (1996); Gillian D. TriggS, INTERNATIONAL LAW: CONTEMPORARY PRINCIPLES AND PRACTICES 249 ( $2 \mathrm{~d}$ ed. 2010).

26. CRAWFORD, supra note 16, at 46 ("Evidently, States are territorial entities."); id. at 221-22 (citing multiple authorities for the conclusion that, without territory, the Holy See cannot be a state).

27. See Prosecutor v. Ngirabatware, Case No. ICTR-99-54-T, Decision on Defence Motion Requesting an Order Directed to the Holy See, $\mid 11$ (Int'l Crim. Trib. for Rwanda Mar. 31, 2010) ("The 
a jurisdiction, but also a sovereign international actor, albeit an actor without territory, fulfilling an unusual mission. ${ }^{28}$

Part of the confusion over its legal personality may be attributed to its peculiar institutional history. It is argued that the Holy See has been a sovereign entity since the time of the Byzantine Empire. ${ }^{29}$ In centuries past, the Holy See had sovereignty over the Papal States, ${ }^{30}$ which could suggest that the Holy See was a territorial entity, i.e. a state. However, when the Holy See lost its control over the Papal States in 1870, it retained its international legal person status, practicing the acts normally associated with that personality. ${ }^{31}$ Had it been a state, it would have ceased to exist upon the loss of its territory. Furthermore, with the Lateran Accords of 1929, the Kingdom of Italy recognized that the legal personality of the Holy See continued uninterrupted, ${ }^{32}$ and that it would receive "sovereignty" over the territory that became the Vatican City State. ${ }^{33}$

Some authorities hold that the Catholic Church is the international legal person, ${ }^{34}$ or that the Catholic Church is the same person as the Holy See. ${ }^{35}$ In this view, the Holy See is merely the Government of the Catholic Church, which is the true international legal person. ${ }^{36}$ While the Church and the See are deeply intertwined, the Holy See is the entity that is consistently

Holy See is considered a State by the international community."); Arms Trade Treaty [ATT], Final Report, 1 15, ATT Doc. No. ATT/CSP1/2015/6 (Aug. 27, 2015).

28. See Comments of the Holy See on the Concluding Observations of the Committee on the Rights of the Child, Holy SEE, para. 14 [hereinafter Comments of the Holy See], http://www.vatican.va/ roman_curia/secretariat_state/2014/documents/rc-seg-st-20140205_concluding-observations-rightschild_en.html [https://perma.cc/S8XZ-NDUM] (last visited Jan. 21, 2021).

29. See CRAWFORD, supra note 16, at 221; Gustav Schnürer, States of the Church, in 14 THE CATHOLIC ENCYClopedia: AN INTERNATIONAL WORK OF REFERENCE ON THE CONSTITUTION, DOCTRINE, DisCIPLINE, AND HISTORY OF THE CATHOLIC CHURCH 259-60 (Charles George Herbermann et al. eds., 1912) (discussing, inter alia, the Donation of Sutri and Donation of Pepin, both granting territory and sovereignty).

30. See CRAWFORD, supra note 16, at 221-22.

31. See id.; CARDINALE, supra note 15, at 88; Kunz, supra note 23, at 309.

32. See Lateran Accords, supra note 9.

33. See id. arts. 3, 26.

34. See Agreement to Amend the 1929 Lateran Concordat, Holy See-It., art. 1, Feb. 18, 1984, 24 I.L.M. 1589 [hereinafter Agreement Between the Italian Republic and the Holy See] ("The Italian Republic and the Holy See reaffirm that the State and the Catholic Church are, each in its own order, independent and sovereign... ."); Pío Ciprotti, The Holy See: Its Function, Form, and Status in International Law, 8 CONCILIUM 63, 63-73 (1970).

35. See Gaetano Arangio-Ruiz, On the Nature of the International Personality of the Holy See, 29 REvUe BELGE DE DRoIT INT’L [R.B.D.I.] 354, 367 (1996) (Belg.) (“[T]he acting or contracting party is always, from the viewpoint of general international law, the Holy See (or the Roman Church).").

36. See Noel Dias, Roman Catholic Church \& International Law, 13 SRI LANKA J. INT'L L. 107, 112 (2001); Helmut Brunner, La Santa Sede y el Derecho Internacional: El Amparo Moral en el Tratado de Paz y Amistad Chileno-Argentino, in El Tratado de PAZ y Amistad EnTRe Chile y Argentina 49-54 (Raymundo Barros Charlín \& Rodrigo Díaz Albónico eds., 1988). 
acknowledged to be the international legal person with which states enter into international relations. ${ }^{37} \mathrm{~A}$ church is usually understood to be a community of belief, ${ }^{38}$ not a coherent person, at least legally. In terms of its structure, the Church is a communion of many dioceses each with a bishop. ${ }^{39}$ While a church might have a role in bringing its moral views to international law, it is hard to see that a church would submit to the duties of international law, or that it could truly discharge any of the other regular functions of being an international legal person. While a church could not be an international legal person, the Holy See does appear to be capable of discharging those international duties. In any event, the Holy See takes the position that there is a distinction between itself and the Catholic Church generally, "which is also a non-territorial entity and may be defined as a spiritual community of faith, hope and charity constituted as a visible society founded on the communion of faith, sacraments, discipline, and governance by its internal legal system, namely canon law." 41 This position has been affirmed by courts in litigation. ${ }^{42}$ Therefore, the Church and the Holy See need to be viewed as distinct entities, with only the latter being a sovereign, international legal person. ${ }^{43}$ The Holy See is not the Church, but rather it is the central governing authority of the Church. ${ }^{44}$

37. See, e.g., infra notes 49-58 (documenting the treaties to which the Holy See is party in its own name and not that of the Church); U.S. Relations with the Holy See, U.S. DEP'T STATE (Aug. 27, 2020) [hereinafter U.S. Relations with the Holy See], https://www.state.gov/u-s-relations-with-the-holy-see/ [https://perma.cc/9F9G-3GLL] (describing relations with the Holy See as an international legal person that is also the government of the Catholic Church).

38. See Juan José Ruda Santolaria, La Iglesia Católica y el Estado Vaticano como Sujetos de Derecho Internacional, 35 ARCHIVUM HistORIAE PonTIFICIAE [A.H.P.] 297, 297 (1997) (It.).

39. See Fundamental Agreement Between the Holy See and the State of Israel, Holy See-Isr., art. 13, § 1, Dec. 30, 1993, 86 Acta Apost. Sedis 716 [hereinafter Fundamental Agreement Between the Holy See and the State of Israel] ("In this Agreement the Parties use these terms in the following sense: a) 'The Catholic Church' and 'the Church' - including, inter alia, its Communities and institutions; b) 'Communities' of the Catholic Church - meaning the Catholic religious entities considered by the Holy See as Churches sui iuris and by the State of Israel as Recognized Religious Communities .....").

40. See List of Issues in Relation to the Second Periodic Report, supra note 9, ๆ 8 ("The Holy See is related but separate and distinct from the Catholic Church, which is also a non-territorial entity and may be defined as a spiritual community of faith, hope and charity constituted as a visible society founded on the communion of faith, sacraments, discipline, and governance by its internal legal system, namely canon law."); see also id. 140.

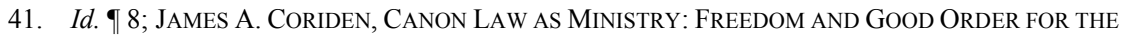
CHURCH 142 (2000).

42. See Doe v. Holy See, 557 F.3d 1066, 1080 (9th Cir. 2009); Black, supra note 12 at 317-19.

43. See Santolaria, supra note 38 , at 297-302.

44. See CRAWFORD, supra note 16, at 225; U.S. Relations with the Holy See, supra note 37; Holy See: Cardinal Poupard's Views on Islam (June 27, 2006, 7:59 AM), https://wikileaks.org/ plusd/cables/06VATICAN122_a.html [https://perma.cc/A248-29VT] ("[T]he Pope is the chief authority for a Church of one billion Catholics ....”). 
Following from the above, the Holy See is an international legal person. In contemporary times, this personality continues to be recognized in the international community and the See has been acknowledged to have the capacity to engage other international persons on the international plane. In fact, it fiercely defends its international legal personality. ${ }^{45}$

\section{The Holy See's Engagement on the International Plane}

Because the Holy See is an international legal person, it has the capacity to bear international rights and obligations. It exercises this capacity in various ways, chiefly by entering into treaties and sending and receiving legations. This practice not only reaffirms that it is an international legal person, but also establishes a consistent practice of entering into international agreements where the Holy See is the party. These acts also affirm the Holy See's commitment to respect and promote international law. ${ }^{46}$

One of the more important modes of engagement is the sovereign capacity to enter into international agreements. ${ }^{47}$ The Holy See has adhered to a wide range of bilateral and multilateral treaties, ${ }^{48}$ including the Geneva

45. See UK Irks Holy See with Embassy Changes (Aug. 9, 2005, 4:21 PM), https://wikileaks.org/ plusd/cables/05VATICAN507_a.html [https://perma.cc/4QDK-D45Y] ("The UK has rubbed the Holy See the wrong way with two recent moves that many at the Vatican have taken as slights - or worse. First the British irked the Vatican by moving its embassy to the Holy See into the compound housing its mission to Italy - a diplomatic faux pas at the Vatican. Britain will maintain a separate mission to the Holy See with its own ambassador, but some see the co-location as a threat to the Vatican's policy of not accepting dual accreditation to both Italy and the Holy See of a single ambassador and embassy.").

46. See Tauran's Lecture, supra note 13 ("The Holy See [has] . . certain priorities, or rather, certain principles, without which there is no civilization: . . . . the establishment of an international order that is founded on justice and rights... . The Holy See has always expressed its esteem for international law... I I am thinking, for example, of the founding texts and resolutions of the United Nations, the Council of Europe and the OSCE. I also want to mention new concepts that have fortunately entered into international law today, such as the duty of humanitarian intervention, and the formulation of the rights of minorities.") (emphasis in original).

47. See Summary Records of the 669th Meeting, [1962] 1 Y.B. Int'1 L. Comm'n 267, 267-68, U.N. Doc. A/CN.4/SR.669; Int'l Law Comm'n, Rep. on the Work of Its Fifty-First Session, 54 U.N. GAOR Supp. (No. 10), U.N. Doc. A/54/10 (1999).

48. See Convenio Entre la Santa Sede y la República del Paraguay Sobre Jurisdicción Eclesiástica Castrense y Asistencia Religiosa a las Fuerzas Armadas, Holy See-Para., Nov. 26, 1960, 54 Acta Apost. Sedis 22; Agreement Between the Holy See and the Argentine Republic, Arg.-Holy See, Oct. 10, 1966, 601 U.N.T.S. 187 [hereinafter Agreement Between the Holy See and the Argentine Republic]; Agreement for the Application of Safeguards in Connection with the Treaty on the Non-Proliferation of Nuclear Weapons, Holy See-IAEA, June 26, 1972, 895 U.N.T.S. 155 [hereinafter Agreement for the Application of Safeguards]; Agreement Concerning Mutual Relations, Holy See-Spain, July 28, 1976, 1030 U.N.T.S. 357 [hereinafter Agreement Concerning Mutual Relations]; Agreement Concerning Economic Matters, Holy See-Spain, Jan. 3, 1979, 1154 U.N.T.S. 39 [hereinafter Agreement Concerning Economic Matters]; Convention Entre le Saint-Siège et la Principauté de Monaco, Holy See-Monaco, July 25, 1981, 73 Acta Apost. Sedis 651; Acuerdo Entre la Santa Sede y la República de Bolivia Sobre Asistencia Religiosa a las Fuerzas Armadas y Fuerzas de la Policía Nacional, Bol.-Holy See, December 1, 1986, 81 Acta Apost. Sedis 528; Acordo Entre a Santa Sé e a República Federativa do Brasil Sobre Assistência Religiosa às 
Conventions on the Law of War, ${ }^{49}$ the Convention relating to the Status of Refugees, ${ }^{50}$ the Vienna Convention on Diplomatic Relations, ${ }^{51}$ the Vienna Convention on Consular Relations,$^{52}$ the Vienna Convention on the Law of Treaties, ${ }^{53}$ the International Convention on the Elimination of All Forms of Racial Discrimination, ${ }^{54}$ the Convention against Torture and Other Cruel,

Forças Armadas, Braz.-Holy See, Oct. 3, 1989, 82 Acta Apost. Sedis 126; Fundamental Agreement Between the Holy See and the State of Israel, supra note 39, pmbl.; Fünfter Zusatzvertrag Zwischen dem Heiligen Stuhl und der Republik Österreich zum Vertrag Zwischen dem Heiligen Stuhl und der Republik Österreich zur Regelung von Vermögensrechtlichen Beziehungen, Austria-Holy See, Dec. 21, 1995, 90 Acta Apost. Sedis 95; Monetary Agreement Between the European Union and the Vatican City State, European Union-Vatican, Dec. 17, 2009, 2010 O.J. (C 28) 13; Opinion of the European Central Bank of 1 September 2003 at the Request of the Council of the European Union on a Recommendation for a Council Decision on the Approval of Certain Amendments to Be Made to Articles 3 and 7 of the Monetary Agreement Between the Italian Republic, on Behalf of the European Community, and the Vatican City State and, on its Behalf, the Holy See and Authorising the Italian Republic to Give Effect to These Amendments, COM (2003) 387 final (Sept. 1, 2003); James Fantau, Rethinking the Sovereign Status of the Holy See: Towards a Greater Equality of States and Greater Protection of Citizens in United States Courts, 19 CARDOZO J. INT'L \& COMP. L. 487 (2011); Kunz, supra note 23, at 309.

In addition, the Holy See appears to contribute to the development of customary international law. See, e.g., Summary Records of the 387th Meeting: Diplomatic Intercourse and Immunities, [1957] 1 Y.B. Int'1 L. Comm'n 18, ๆ 14, U.N. Doc. A/CN.4/SER.A/1957; Summary Records of the 639th Meeting: Law of Treaties, [1962] 1 Y.B. Int'1 L. Comm'n 57, q 6, U.N. Doc. A/CN.4/SER.A/1962; Summary Records of the 1049th Meeting: Relations Between States and International Organizations, [1970] 1 Y.B. Int'1 L. Comm'n 33, 9甲 5-6, U.N. Doc. A/CN.4/SER.A/1970; Abdullah El-Erian (Special Rapporteur on Representation of States in Their Relations with International Organizations), Sixth Rep. on Relations Between States and International Organizations, U.N. Doc. A/CN.4/241\&ADD.1-6 (1971), reprinted in [1971] 2 Y.B. Int'1 L. Comm'n 1, at 86, U.N. Doc. A/CN.4/SER.A/1971/ADD.1 (Part 1); Roberto Ago (Special Rapporteur on State Responsibility), Eighth Rep. on State Responsibility, U.N. Doc. A/CN.4/318\&ADD.1-4, reprinted in [1979] 2 Y.B. Int'l L. Comm'n 3, q 34, U.N. Doc. A/CN.4/SER.A/1979/ADD.1 (Part 1); Alain Pellet (Special Rapporteur on Reservations to Treaties), Third Rep. on Reservations to Treaties, U.N. Doc. A/CN.4/491\&ADD.1-6, reprinted in [1998] 2 Y.B. Int'1 L. Comm'n 221, 『 363, U.N. Doc. A/CN.4/SER.A/1998/Add.1 (Part 1).

49. See Convention for the Amelioration of the Condition of the Wounded in Armies in the Field, Aug. 22, 1864, 129 C.T.S. 361 (entered into force June 22, 1865; no longer in force today), reprinted in THE LAwS OF ARMED CONFLICTS 280-81 (Dietrich Schindler \& Jiri Toman eds., 1988).

50. See Convention Relating to the Status of Refugees, adopted July 28, 1951, 189 U.N.T.S. 137 [hereinafter 1951 Refugee Convention].

51. Vienna Convention on Diplomatic Relations, opened for signature Apr. 18, 1961, 500 U.N.T.S 95 (entered into force Dec. 13, 1972).

52. Vienna Convention on Consular Relations and Optional Protocol on Disputes, adopted Apr. 24, 1963, 596 U.N.T.S. 261 (entered into force Dec. 24, 1969).

53. Vienna Convention on the Law of Treaties, opened for signature May 23, 1969, 1155 U.N.T.S. 331 (entered into force Jan. 27, 1980) [hereinafter Vienna Convention on the Law of Treaties].

54. See G.A. Res. 2106 (XX) A, annex, International Convention on the Elimination of All Forms of Racial Discrimination (Dec. 21, 1965). 
Inhuman or Degrading Treatment or Punishment, ${ }^{55}$ and the Convention on the Rights of the Child. ${ }^{56}$

Notably, only states may be parties to these treaties. ${ }^{57}$ It remains unclear why the Holy See, a non-state entity, was invited to participate without objection by the other states. ${ }^{58}$ It is accepted practice for states to lodge such objections to participation when they do not believe an entity is qualified to adhere to a treaty. ${ }^{59}$

In addition to treaties, the Holy See also enters into "concordats." Concordats are also treaties, though their content focuses on the protection and regulation of the Holy See, the Catholic Church, and the practice of the Catholic faith within a state. ${ }^{60}$ Concordats provide for the legal personality

55. See Convention Against Torture and Other Cruel, Inhuman or Degrading Treatment or Punishment, opened for signature Dec. 10, 1984, 1465 U.N.T.S. 85 (entered into force June 26, 1987) [hereinafter UNCAT]; G.A. Res. 39/46, annex, Convention Against Torture and Other Cruel, Inhuman or Degrading Treatment or Punishment (Dec. 10, 1984).

56. Convention on the Rights of the Child, supra note 1; see G.A. Res. 44/25, annex, Convention on the Rights of the Child (Sept. 2, 1990); G.A. Res. 54/263, annexes I-II, Optional Protocols to the Convention on the Rights of the Child on the Involvement of Children in Armed Conflict and on the Sale of Children, Child Prostitution and Child Pornography (May 25, 2000).

57. See supra notes 41, 43-47; Doe v. Holy See, 557 F.3d 1066 (9th Cir. 2009).

58. See, e.g., Status of the Vienna Convention on the Law of Treaties, UnITED NATIONS TREATY COLLECTION [hereinafter Status of the VCLT], https://treaties.un.org/Pages/ViewDetailsIII.aspx?src= TREATY\&mtdsg_no=XXIII-1\&chapter=23\&Temp $=$ mtdsg3\&clang $=$ en [https://perma.cc/V6LU-46JS] (last visited Feb. 25, 2021); see generally William Thomas Worster, Functional Statehood in Contemporary International Law, 46 BROOK. J. INT'L L. 39 (2020) [hereinafter Worster, Functional Statehood in Contemporary International Law] (explaining that the international community engages with the Holy See as a state-like entity even though the Holy See is not considered a state).

59. See Situation in the State of Palestine, ICC-01/18-12, Prosecution Request Pursuant to Article 19(3) for a Ruling on the Court's Territorial Jurisdiction in Palestine (Int'l Crim. Ct., Pre-Trial Chamber I, Jan. 22, 2020) (arguing that the Court may exercise jurisdiction over acts committed in Palestine on the basis of Palestine's adherence to the Rome Statute, notwithstanding Israel's objection to its lack of statehood); Palestine v. Isr., Comm. on the Elimination of Racial Discrimination, Commc'n, U.N. Doc. CERD/C/100/5 (Dec. 12, 2019) (finding that the inter-state complaint by Palestine against Israel was admissible notwithstanding Israel's objection to Palestine's adherence to the CERD); Status of the International Convention on the Elimination of All Forms of Racial Discrimination, UNITED NATIONS TREATY COLLECTION, https://treaties.un.org/Pages/ViewDetails.aspx?src=TREATY\&mtdsg_no=IV2\&chapter=4\&clang=_en [https://perma.cc/4Q5M-8T7R] (last visited Feb. 24, 2021) (documenting declarations by Bahrain, Iraq, Kuwait, Libya, Syrian Arab Republic, United Arab Emirates and Yemen that adherence did not constitute recognition of Israel, and documenting Israel's reply that such statements are "political pronouncements" and that "the Convention is not the proper place" for them); see generally William Thomas Worster, Territorial Status Triggering a Functional Approach to Statehood, 8 PA. ST. J.L. \& INT'L AFF. 118 (2020) [hereinafter Worster, Territorial Status Triggering a Functional Approach to Statehood] (documenting cases in which parties to treaties objected to territories' joining the treaty because they believed those territories did not qualify as states).

60. See Konkordat Zwischen dem Heiligen Stuhl und dem Deutschen Reich, Ger.-Holy See, July 20, 1933, 25 Acta Apost. Sedis 390; Acordo Missionário Entre a Santa Sé e a República Portuguesa, Holy See-Port., May 7, 1940, 32 Acta Apost. Sedis 235; Concordat Between the Holy See and Spain, Holy See-Spain, Aug. 27, 1953, 1219 U.N.T.S. 49 [hereinafter Concordat Between the Holy See and Spain]; 
of the church within the relevant state, ${ }^{61}$ and provide for the legal personality of various organizations and bodies constituted under canon law and operating within the domestic law of the state. ${ }^{62}$ They may also permit the Holy See to apply canon law in administering church entities, including establishing and abolishing those entities, ${ }^{63}$ among other rights.

In addition to having the capacity to enter into international agreements, the Holy See also has the capacity for a range of acts that are typically reserved for other international legal persons. It holds the right to conduct international relations, ${ }^{64}$ maintain international claims, ${ }^{65}$ send or receive legations, ${ }^{66}$ and enjoy immunity and inviolability. ${ }^{67}$ It is a member of a few international organizations, such as the International Atomic Energy Agency $(\text { IAEA })^{68}$ and the Universal Postal Union (UPU), ${ }^{69}$ and, though not a

Concordato Entre la Santa Sede y la República Dominicana, Dom. Rep.-Holy See, June 16, 1954, 46 Acta Apost. Sedis 433; Konkordat Między Stolicą Apostolską i Rzecząpospolitą Polską, Holy See-Pol., July 28, 1993, 90 Acta Apost. Sedis 310 [hereinafter Concordat Between the Holy See and the Republic of Poland].

61. See Accordo Tra la Santa Sede e la Repubblica di Croazia Circa Questioni Giuridiche, Croat.Holy See, art. 2, Dec. 19, 1996, 89 Acta Apost. Sedis 277 [hereinafter Holy See and Republic of Croatia Agreement 1996].

62. See Agreement Between the Holy See and the Republic of Latvia, Holy See-Lat., Nov. 8, 2000, 95 Acta Apost. Sedis 102 [hereinafter Agreement Between the Holy See and the Republic of Latvia]; Concordat Between the Holy See and the Republic of Poland, supra note 60; Agreement Between the Holy See and the Republic of Lithuania on Co-operation in Education and Culture, Holy See-Lith., May 5, 2000, 92 Acta Apost. Sedis 783; Agreement Between the Holy See and the Republic of Estonia, Est.Holy See, Feb. 15, 1999, 91 Acta Apost. Sedis 414.

63. See Holy See and Republic of Croatia Agreement 1996, supra note 61, art. 3.

64. See, e.g., U.N. GAOR, 20th Sess., 1347th plen. mtg. at 2-5, U.N. Doc. A/PV.1347 (Oct. 4, 1965); U.N. GAOR, 34th Sess., 17th plen. mtg. at 349-53, U.N. Doc. A/34/PV.17 (Oct. 2, 1979); U.N. GAOR, 50th Sess., 20th plen. mtg. at 2-6, U.N. Doc. A/50/PV.20 (Oct. 5, 1995); U.N. GAOR, 62nd Sess., 95th plen. mtg. at 3-6, U.N. Doc. A/62/PV.95 (Apr. 18, 2008); U.N., REPORT OF THE FOURTH World CONFERENCE ON Women, at 159-64, U.N. Doc. A/CONF.177/20/Rev.1, U.N. Sales No. 96.IV.13 (1996) (providing the views of the Holy See on the Report's conclusions).

65. See Lateran Accords, supra note 9, art. 3.

66. See CRAWFORD, supra note 16, at 221; Holy See v. Starbright Sales Enters., Inc., 102 I.L.R. 163 (S.C., Dec. 1, 1994) (Phil.); Guadalupe v. Italian Ass'n of S. Cecilia, 8 I.L.R. 151 (Ct. 1st Instance Rome 1937); European Parliament, Question for Written Answer E-003218/13 to the Commission (VicePresident/High Representative) Nuno Teixeira (PPE), 2013 O.J. (C 11E) 540 [hereinafter Question for Nuno Teixeira].

67. See Ryngaert, supra note 16; Cass., 21 Maggio 2003, n. 22516, 86 RIVISTA DI DIRITTO INTERNAZIONALE 821 (2003) (It.).

68. See Statute of the International Atomic Energy Agency: Ratifications and Acceptance, Oct. 26, 1956, 293 U.N.T.S. 359 [hereinafter IAEA Statute Ratification]; Amendment to the Statute of the IAEA, Oct. 4, 1961, 471 U.N.T.S. 334 [hereinafter Amendment to IAEA Statute].

69. See Universal Postal Convention, July 11, 1952, 169 U.N.T.S. 3; Universal Postal Convention: Ratifications and Accession by Various States, Feb. 16, 1954, 186 U.N.T.S. 356 [hereinafter Ratification of UPC]; Universal Postal Union, July 10, 1964, 611 U.N.T.S. 7; Constitution of the Universal Postal Union: Ratifications by the Holy See and Greece, June 27, 1968, 639 U.N.T.S. 368 [hereinafter Ratification of UPU Constitution]. 
member, participates as an observer at the United Nations ${ }^{70}$ and the European Union, ${ }^{71}$ among others. Joining the United Nations as a full member is still considered an option. $^{72}$

In its foreign relations, the Holy See sends ambassadors, though these individuals operate under the title of "nuncio." As diplomatic agents, these representatives enjoy immunity and inviolability. ${ }^{73}$ Unlike most ambassadors, nuncios have a dual mission, both temporal and ecclesiastical. They serve as the liaison between the church governance in Rome and the local dioceses in their ecclesiastical capacity, ${ }^{74}$ but they also serve as the political representation of the Holy See to the government of the state ${ }^{75}$ and to international organizations such as the Organization for Security and Cooperation in Europe (OSCE) and IAEA. ${ }^{76}$ In their ecclesiastical capacity, nuncios will report to Rome on religious matters arising in the dioceses ${ }^{77}$ and explain religious statements by the Pope. ${ }^{78}$ In their political capacity, they may make representations to the local government ${ }^{79}$ and gather political information. ${ }^{80}$ However, the Code of Canon law states that a Papal diplomat is intended to have the "principal function ... to make stronger and more effective the bonds of unity which exist between the Apostolic See [Holy See] and particular churches." 81 This duty includes "protect[ing]" the mission of the church with state officials, ${ }^{82}$ reporting to the Holy See on the

70. See CRAWFORD, supra note 16, at 156; CARDINALE, supra note 15, at 265; G.A. Res. 58/314, Participation of the Holy See in the Work of the United Nations (July 16, 2004).

71. See Working with the Holy See in International Organizations - Powerful Ally and Occasional Foe (July 23, 2002, 2:56 PM) [hereinafter Working with the Holy See], https://wikileaks.org/plusd/cables/ 02VATICAN3633_a.html [https://perma.cc/Q8J5-7ABP].

72. See Sodano Hints at Shift in Holy See UN Status; Takes Aim at Preemptive Strike, EU Constitution (Nov. 25, 2002, 2:26 PM), https://wikileaks.org/plusd/cables/02VATICAN5714_a.html [https://perma.cc/MQG6-7EDV].

73. See Lateran Accords, supra note 9, art. 12

74. See 1983 CODE cs.364-65; CARDINALE, supra note 15, at 393.

75. See 1983 CODE c. $363, \S 1$.

76. See Holy See: New Nuncio to Sudan (Jan. 25, 2007, 8:52 AM), https://wikileaks.org/ plusd/cables/07VATICAN24_a.html [https://perma.cc/UKU7-J58G].

77. See Tauran's Lecture, supra note 13.

78. See Holy See: Pope's Regensburg Speech Ignites Firestorm, Leads to Papal Apology (Sept. 18, 2006, 1:37 PM) [hereinafter Pope's Regensburg Speech], https://wikileaks.org/plusd/cables/ 06VATICAN199_a.html [https://perma.cc/Y3EC-YEX6].

79. See Holy See Presses Dialogue; East Timorese Jesuit Critical of Timor Protests (May 4, 2005, 6:26 AM) [hereinafter Holy See Presses Dialogue], https://wikileaks.org/plusd/cables/05VATICAN473 _a.html [https://perma.cc/UP3A-JW3S].

80. See Haiti: Holy See Awaits New Nuncio (July 16, 2004, 4:38 AM), https://wikileaks.org/plusd/ cables/04VATICAN2767_a.html [https://perma.cc/4EFD-TWMD].

81. 1983 CODE c.364; CARDINALE, supra note 15, at 32, 175; see Morss, supra note 23, at 934 (describing papal diplomats as "priests first and diplomats second").

82. 1983 CODE c.364(7). 
activities of local churches ${ }^{83}$ assisting in church governance ${ }^{84}$ and interfaith dialogue, ${ }^{85}$ generally promoting "peace, progress, and cooperative effort of peoples, ${ }^{\circ 66}$ and any other activity requested by the Holy See. ${ }^{87}$ Nuncios operate under the oversight of the Secretariat of State Section for Relations with States ${ }^{88}$ and ultimately the Pope.

From the foregoing, it is clear that the Holy See is an international legal person, albeit an unusual person. Distinguishing its personality from that of, for example, international organizations, the Holy See argues that its personality is similar to that of states in that it is "original" and not "derived." ${ }^{89}$ The distinction between original and derived personalities focuses on the process and authority involved in the act creating the person: derived persons derive their personality from existing subjects in international law, whereas original persons exist independently of this deliberately creative act. ${ }^{90}$

\section{The Holy See's Moral and Political Role}

Beyond its functional engagement in international relations alongside states, the Holy See nonetheless views itself as distinct from states due to its unique role providing a moral voice in international relations,${ }^{91}$ to which its international legal rights and duties are secondary. ${ }^{92}$ It is true that nuncios

83. Id. c.364(1).

84. See id. c.364, 364(2).

85. See id. c.364, 364(6).

86. Id. c.364(5).

87. Id. c.364(8).

88. See PASTOR BONUS, art. 45, available at https://www.vatican.va/content/john-paulii/en/apost_constitutions/documents/hf_jp-ii_apc_19880628_pastor-bonus.html [https://perma.cc/DJ4BGKF9]; Holy See on Madrid Inter-Religious Conference (Aug. 4, 2008, 1:55 PM), https://wikileaks.org/ plusd/cables/08VATICAN61 a.html [https://perma.cc/MUQ9-4RSZ].

89. List of Issues in Relation to the Second Periodic Report, supra note 9, 96.

90. See Legality of the Threat or Use of Nuclear Weapons, Advisory Opinion, 1996 I.C.J. 66, 925 (July 8); Reparation for Injuries Suffered in the Service of the United Nations, Advisory Opinion, 1949 I.C.J. 174, 178-79 (Apr. 11); see also Worster, Functional Statehood in Contemporary International Law, supra note 58.

91. See Comments of the Holy See, supra note 28 ("In regard to recommendations concerning the accession to international instruments contained in Concluding Observations ... paragraphs 44 (j) and 62 , the Holy See reaffirms that it operates within the international community like other subjects of international law, while maintaining its specific mission and end.") (emphasis in original) (citation omitted); see also Human Rights at Center of Holy See Diplomacy (Mar. 26, 2008, 10:07 AM), https://wikileaks.org/plusd/cables/08VATICAN32_a.html [https://perma.cc/7523-T4LE].

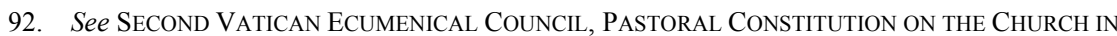
THE Modern World [GUAdium ET SPES] [CONSTITUTION] December 7, 1965 ("Indeed, [the Holy See] stands ready to renounce the exercise of certain legitimately acquired rights if it becomes clear that their use raises doubt about the sincerity of its witness ...."). 
often make efforts to avoid mixing their ecclesiastical and political duties. ${ }^{93}$ In the view of the Holy See, this role implicitly limits its responsibility in international law. ${ }^{94}$ However, the moral and political roles cannot be so easily separated, and the Holy See does indeed engage in political issues, ${ }^{95}$ and, by its own admission, participate in international law. ${ }^{96}$ In addition, many states are also motivated by moral reasons in their international relations. The nature of the Holy See's international participation means that it can be responsible for violations of international law, similar to states, notwithstanding the fact that it pursues a moral role in the international community.

Some of the actions of the Holy See can be identified either as political or as a part of its religious mission, and thus more clearly implicating international law or not. For example, sometimes, the Holy See is focused on the politics surrounding religious practice. The Holy See has resisted Chinese intervention in clerical appointments within Chinese territory, ${ }^{97}$ pursued inter-religious dialogue, ${ }^{98}$ and pushed for the EU Constitution to recognize Europe's Christian heritage. ${ }^{99}$ At other times,

93. See Holy See Presses Dialogue, supra note 79.

94. Comments of the Holy See, supra note 28 ("For this reason, the Holy See has always sought to become a part of international multilateral conventions regulating various areas, also on behalf of Vatican City State, with the necessary evaluation of these conventional norms in respect to its nature and to the particular function of its internal juridical system.").

95. See Working with the Holy See, supra note 71 ("SUMMARY: THE HOLY SEE ACTIVELY SEEKS TO INFLUENCE THE POLICIES OF INTERNATIONAL ORGANIZATIONS AND INSTITUTIONS AND PARTICIPATES INTENSELY IN THE MOST IMPORTANT OF THESE TO PROMOTE ITS OWN AGENDA, PARTICULARLY ITS POSITION ON SEXUALITY AND THE TRADITIONAL FAMILY.").

96. See id.

97. See Holy See and the PRC, Time for Reconciliation? (Jan. 17, 2003, 1:22 PM) [hereinafter Holy See and the PRC], https://wikileaks.org/plusd/cables/03VATICAN215_a.html [https://perma.cc/ 2WMC-86J] ("ASSESSING THE OBSTACLES TO NORMALIZATION OF RELATIONS BETWEEN THE HOLY SEE AND CHINA, HOLY SEE MFA CHINA DIRECTOR MSGR. ROTAGRAZIOSI SAID THAT THE CATHOLIC CHURCH IN CHINA 'MUST BE AUTONOMOUS, BUT COULD NOT BE INDEPENDENT' FROM THE HOLY SEE.”); Holy See: Meeting with Cardinal Dias (Aug. 9, 2006, 2:57 PM), https://wikileaks.org/plusd/cables/06VATICAN166_a.html [https://perma.cc/ 46HJ-JG3R]; Diplomatic, PRC - Holy See Relations in Flux; Vatican Convenes China Policy Meeting (Jan. 29, 2007, 4:39 PM), https://wikileaks.org/plusd/cables/07VATICAN30_a.html [https://perma.cc/ F4M9-KXR3]; China - Holy See: No Agreement on Catholic Bishop Ordinations (Dec. 21, 2007, 3:41 PM), https://wikileaks.org/plusd/cables/07VATICAN193_a.html [https://perma.cc/M5NT-MFVC].

98. See Holy See on Saudi Proposal for Unga Interfaith High Level Dialogue (Oct. 15, 2008, 2:59 PM) [hereinafter Holy See on Saudi Proposal], https://wikileaks.org/plusd/cables/08VATICAN77 _a.html [https://perma.cc/3F9M-U2CT] (discussing "inter-religious dialogue" between the Vatican and the Saudi government and the possibility of the Vatican agreeing to discuss the dialogue at the U.N.).

99. See The Holy See and the European Constitution (Nov. 27, 2002, 1:53 PM), https:// wikileaks.org/plusd/cables/02VATICAN5753_a.html [https://perma.cc/56PU-24KT] (“ALTHOUGH THE HOLY SEE IS PRESSING HARD FOR THE EUROPEAN CONSTITUTION TO RECOGNIZE THE CONTINENT'S CHRISTIAN HERITAGE . . ..”). 
however, its political role is more clearly separated from its religious role. For example, the Holy See is one of the few entities in the world that continue to recognize the Republic of China on Taiwan Island as the Government of China; ${ }^{100}$ in the past, it recognized Kosovo. ${ }^{101}$ It has intervened on matters ranging from UN reform, ${ }^{102}$ to climate change, ${ }^{103}$ to political prisoners, ${ }^{104}$ to Turkish admission to the EU, ${ }^{105}$ to the peace process in Israel and Palestine. $^{106}$

Nevertheless, the concerns of politics and religion often remain deeply intertwined, such as when the Holy See uses its political role to advocate for religious ends. ${ }^{107}$ For example, it instructs its nuncios to include religious teaching in diplomatic discussions. ${ }^{108}$ But it also uses its religious role to achieve political ends. For example, the Holy See has asked non-diplomatic clergy to become involved in diplomatic communications, ${ }^{109}$ used religious

100. See Holy See and the PRC, supra note 97.

101. See Holy See Has Recognized Kosovo “De Facto,” Says Vatican Official (Apr. 30, 2008, 10:15 AM), https://wikileaks.org/plusd/cables/08VATICAN38_a.html [https://perma.cc/74YH-MCJ5] ("The Holy See is not ready to formally recognize Kosovo but will continue to promote dialogue in a way that implicitly acknowledges and respects Kosovo's de facto independence."); (SBU) Holy See Not Considering Recognition of South Ossetia and Abkhazia (Aug. 29, 2008, 3:44 PM), https://wikileaks.org/plusd/cables/08VATICAN64_a.html [https://perma.cc/XHV3-9VPR].

102. See Holy See Supports Comprehensive Approach to UN Reform (July 27, 2005, 1:47 PM), https://wikileaks.org/plusd/cables/05VATICAN503_a.html [https://perma.cc/C6PF-M479].

103. See Holy See Reviews Climate Change with APEC Diplomats (Oct. 10, 2007, 4:11 PM), https://wikileaks.org/plusd/cables/07VATICAN147_a.html [https://perma.cc/TF5F-VBJK].

104. See Holy See Secretary of State Talks About Cuba (Mar. 7, 2008, 1:30 PM), https://wikileaks.org/plusd/cables/08VATICAN31_a.html [https://perma.cc/TB5V-4LBG].

105. See Pope's Regensburg Speech, supra note 78 ("As Cardinal Ratzinger, he was also known for his belief that Turkey should not enter the European Union.”).

106. See Holy See Calls in Ambassador to Convey Concerns on Middle East and Bethlehem (Dec. 11, 2002, 3:21 PM) [hereinafter Holy See Calls in Ambassador], https://wikileaks.org/plusd/cables/ 02VATICAN5938_a.html [https://perma.cc/GPP8-DTBT]; Holy See on ICJ, Israeli Separation Barrier (Nov. 26, 2003, 7:11 AM), https://wikileaks.org/plusd/cables/03VATICAN5365_a.html [https:// perma.cc/E5BX-2CYY].

107. See Economic and Social Council Dec. 244 (LXIII), U.N. Doc. E/6020, at 7 (July 22, 1977); U.N. SCPR, 58th Sess., 4709th mtg. at 33-34, U.N. Doc. S/PV.4709 (Feb. 19, 2003); U.N. SCPR, 63rd Sess., 6017th mtg. at 12-13, U.N. Doc. S/PV.6017 (Nov. 19, 2008); U.N. SCPR, 64th Sess., 6066th mtg. at 36-37, U.N. Doc. S/PV.6066 (Jan. 14, 2009); U.N. GAOR, 63rd Sess., 71st plen. mtg. at 2, U.N. Doc. A/63/PV.71 (Dec. 18, 2008); Holy See Pleased About Saudi King Meeting with Pope, Interested in InterReligious Dialogue (Nov. 30, 2007, 9:17 AM), https://wikileaks.org/plusd/cables/07VATICAN180 _a.html [https://perma.cc/7Z95-3MCN] ("Ortega explained that the Holy Father treaded softly on the issue of religious freedom for the estimated 1.6 million Christians in Saudi Arabia, eighty percent of whom are believed to be Catholic.").

108. See Holy See: Israeli Views on Hamas, Islam, Fundamental Agreement (June 9, 2006, 10:12 AM) [hereinafter Holy See: Israeli Views], https://wikileaks.org/plusd/cables/06VATICAN104_a.html [https://perma.cc/N8UZ-6ZCV].

109. See Lebanon: Jesuit Scholar Discusses Christian Support for Aoun, Israel, Holy See Role (Dec. 13, 2006, 4:53 PM) [hereinafter Jesuit Scholar Discusses Christian Support], https://wikileaks.org/ 
reconciliation to pursue political and military peace, ${ }^{110}$ appointed cardinals to influence state policy, ${ }^{111}$ encouraged pilgrimages for the benefit of the Israeli tourism industry, ${ }^{112}$ threatened to criticize Israel if it did not receive access to religious sites, ${ }^{113}$ and generally promoted Catholicism. ${ }^{114}$ The Holy See is even on record advocating that it should be awarded governance

plusd/cables/06VATICAN260_a.html [https://perma.cc/DTX6-FQ9P] ("Father Samir . . . f feels the Holy See will continue to work through the Patriarch (rather than directly) in Lebanon. ... [T] he Holy See won't want to go public via its nuncio in Beirut (Archbishop Gatti), and will prefer to work only through Patriarch Sfeir; this is its usual practice everywhere, and Lebanon's politics are especially complicated.").

110. See OSCE Bosnia Head Presses Holy See and Franciscans on Mostar Tensions (Mar. 26, 2004, 6:35 PM), https://wikileaks.org/plusd/cables/04VATICAN1231_a.html [https://perma.cc/7NYL-WQ82] ("OSCE Bosnia Head of Mission Robert Beecroft emphasized the importance of inter-ethnic reconciliation in Mostar for Bosnia's future stability during March 23-24 meetings with the Holy See's Foreign Minister and the Franciscan order's Minister General. . . . Beecroft said a high-level visit from the Holy See and from the Franciscan Minister General to Mostar could enhance the credibility of the international community with the Mostar Croats, while simultaneously helping promote reconciliation and political progress.”).

111. See Holy See/Venezuela: Cardinal's Hat for Urosa Marks Vatican Interest (Feb. 28, 2006, 5:17 PM), https://wikileaks.org/plusd/cables/06VATICAN37_a.html [https://perma.cc/47A6-8P28] ("The move clearly reflects the high level of Holy See interest in Venezuela . . . . The Holy See, preferring a conciliatory approach to Chavez, sees Urosa as assertive without being overly aggressive. One of our best Vatican contacts on Venezuela confirmed to us that Urosa's elevation owes more to political realities than to his theological or pastoral abilities, while also emphasizing that it reflects the importance of the situation in Venezuela rather than a slap at Castillo Lara.").

112. See Holy See: Israeli Views, supra note 108 ("Ben-Hur suggested that at an appropriate time, Israel might seek a commitment from the Holy See for increased pilgrimage to Jerusalem - something that would bring significant economic benefit to Israel — as a consideration.”).

113. See Holy See Calls in Ambassador, supra note 106 ("HE [Holy See Foreign Minister, Archbishop Jean-Louis Tauran] INDICATED THAT IF THE CURFEW WAS NOT LIFTED AND ACCESS TO THE HOLY SITES GUARANTEED, THE POPE WOULD BE COMPELLED TO MAKE A STATEMENT SHARPLY CRITICAL OF ISRAEL FOR RESTRICTING THE FREEDOM OF RELIGION.").

114. See Holy See Views on Belarus (July 18, 2008, 1:34 PM), https://wikileaks.org/plusd/cables/08VATICAN52_a.html [https://perma.cc/Y9FH-JXZ4]; see also Holy See Official Discusses Oriental Churches, Orthodox-Catholic Dialogue, and Israel (Feb. 14, 2008, 4:26 PM), http://wikileaks.org/plusd/cables/08VATICAN23_a.html [https://perma.cc/Y2MW-MKZJ]; Holy See Frustrated over Negotiations with Israel (Dec. 3, 2007, 5:33 PM), http://wikileaks.org/plusd/ cables/07VATICAN183_a.html [https://perma.cc/GD68-BZHT]; Holy See-Israel: No Progress on Fundamental Agreement at Last Meeting (Jan. 4, 2008, 10:59 AM), http://wikileaks.org/plusd/ cables/08VATICAN1_a.html [https://perma.cc/UC35-QW6A] ("The Holy See is also still frustrated with the issue of Israeli visas for Arab clergy and religious. . . . Taxation of Church property remains the most difficult issue (reftel B)."); Holy See Upset About Israeli Single-Entry Visa Policy for Arab Religious (Nov. 21, 2007, 10:02 AM), http://wikileaks.org/plusd/cables/07VATICAN172_a.html [https:// perma.cc/W2FH-URBG] (discussing instances in which church officials intervened in international policy matters affecting clerical travel and other church concerns); Israel: Holy See Cites Problems for Pilgrims (Dec. 9, 2005, 2:32 PM), http://wikileaks.org/plusd/cables/05VATICAN551_a.html [https:// perma.cc/UF3Q-5LC2] (discussing the Holy See's advocacy for freedom of movement for pilgrims to Bethlehem). 
authority over Jerusalem as a part of a final settlement of the IsraeliPalestinian peace process. ${ }^{115}$

While religious institutions are generally nongovernmental organizations, they are not necessarily always so; their religious nature alone does not exclude them from being governmental. ${ }^{116}$ This is true even though, as discussed above, blurred political and religious activity can be rather difficult to separate. In sum, the Holy See's nature permits it to alternatively emphasize its religious or political role as is strategically appropriate, ${ }^{117}$ all the while expressing concerns about mixing politics and religion, ${ }^{118}$ and avoiding explicit political statements by working through its clergy. ${ }^{119}$ But there does not appear to be any reason why its role would limit its responsibility if it indeed violated international law.

\section{B. The Distinction Between the Holy See and the Vatican City State}

In the discussion above, we distinguished between the Holy See and the Catholic Church, and identified the structure, form, functions and role of the Holy See as an international legal person. However, the article has so far omitted a specific discussion of the Vatican City as a distinct entity from the Holy See. In the next section, we will distinguish the Holy See from the Vatican City State, and discuss the interrelationship of these two entities. This discussion, in turn, builds a framework for analysis of whether it is the Holy See or the Vatican City that is party to the CRC, and the scope of obligations under that treaty.

\section{Two Distinct International Legal Persons}

As noted above, the Holy See is, and has been, an international legal person for centuries. Decades after losing the Papal States, it continued to operate as international legal person, though without territory. Ultimately, in 1929, the Holy See entered into the Lateran Accords to secure recognition of

115. See Reut Yael Paz, 'If I Forget Thee, O Jerusalem': Religion, International Law, and Jerusalem, in INTERNATIONAL LAW AND RELIGION: HISTORICAL AND CONTEMPORARY PERSPECTIVES 269-71, 288 (Martti Koskenniemi et al. eds., 2017) ("That the Holy See accepted the de facto existence of the Jewish State in the Holy Land does not however mean that it has given up on the possibility of direct Catholic control of the holy places and the Holy Land, or that it has abandoned its previous aspirations to establish a protectorate of the holy places.").

116. But see Holy Monasteries v. Greece, 301 Eur. Ct. H.R. (ser. A) at 27-28, paras. 48-49 (1994) (holding that the religious communities were non-governmental, after examining their interactions with the state).

117. See Pope's Regensburg Speech, supra note 78.

118. See Holy See on Saudi Proposal, supra note 98 ("The Vatican is uncomfortable about having the UN - a political body - get involved in religious matters.").

119. See Jesuit Scholar Discusses Christian Support, supra note 109. 
its personality and independence, and received the grant of sovereignty over the Vatican City complex. ${ }^{120}$

The best interpretation of the Vatican City State is that it is a distinct legal person from the Holy See. ${ }^{121}$ It is widely regarded as a state in international law, ${ }^{122}$ whereas the Holy See is not. ${ }^{123}$ In many ways, the Vatican City does indeed act as a state. It has its own legislative competence $^{124}$ and legal system, ${ }^{125}$ based on canon law, ${ }^{126}$ although not all of canon law applies within the state, ${ }^{127}$ and in some areas supplementary laws from Italy are applied. ${ }^{128}$ This body of law includes penal laws, ${ }^{129}$

120. See Fantau, supra note 48, at 487-524; Brunner, supra note 36; Ciprotti, supra note 34; C.G. Fenwick, Editorial Commentary, The New City of the Vatican, 23 AM. J. INT'L L. 371, 371-74 (1929).

121. See DuURSMA, supra note 25, at 413; D.J. HARris, CASES AND MATERIALS ON INTERNATIONAL LAW 99 (6th ed. 2004); Holy See v. Starbright Sales Enters., Inc., 102 I.L.R. 163 (S.C., Dec. 1, 1994) (Phil.); Question for Nuno Teixeira, supra note 66, I 1 ("The EU has a Monetary Agreement with the Vatican City State, which is a separate entity from the Holy See under international law."); U.S. Relations with the Holy See, supra note 37.

122. See CERD, Consideration of Reports 2000, supra note 23, \4(c) ("[T] She State of Vatican City. . . has all the characteristics of a State ....”); Special Representative of the City of the Vatican v. Pieciukiewicz, 78 I.L.R. 120, 121-22 (1982) (It.) (affirming the sovereignty of the Vatican City as a state, distinct from Holy See); CRAWFORD, supra note 16, at 225.

123. See Comments of the Holy See, supra note 28, para. 3.

124. See Second Reports of States Parties Due in 1997, supra note 16, \ 109 (citing LAW N. LXXI: ACT ON SOURCES OF LAW art. 1(2) (Vatican)) ("The fundamental law and the laws for VCS, enacted or issued by the Supreme Pontiff, the Pontifical Commission or other authority to whom he has conferred legislative power, are the principal sources of law ....").

125. See 2010 Tip Report Input for Vatican City State/Holy See (Feb. 16, 2010, 10:58 AM) [hereinafter 2010 Tip Report Input], https://wikileaks.org/plusd/cables/10VATICAN29_a.html [https:// perma.cc/N45C-FTMF] ("Vatican City State has a complicated legal system based in part on Italian law, its own laws as defined by the Holy See, and the Canon Law of the Roman Catholic Church. Where Vatican City State has not enacted laws on a specific issue (e.g., TIP) — and when such laws in the Italian penal code are not contrary to Catholic doctrine, Canon Law or other legislation enacted by the Holy See-Italian law may/may be applied.”).

126. See Second Reports of States Parties Due in 1997, supra note 16, ๆ 108 (citing LAW N. LXXI: ACT ON SOURCES OF LAW art. 1(1) (Vatican)).

127. See id. 1 108(a) ("Although an intimate organic relationship of VCS with the Catholic Church exists, not every aspect of canon law is applicable in the temporal governance of VCS. The fact that a given act may also be treated as a religious offense under penal canon law does not preclude prosecution according to the criminal law and procedures of any State. The same is true of VCS ....").

128. See id. ๆ甲 109-10.

129. See id. 99 20(a), 98(a) ("[O]nly the baptized faithful and those belonging to the Catholic Church . . . are bound by penal canon law. Penal canon law addresses disturbances to the public order of the Church, it therefore, briefly treats the subject matter of delicts (e.g. homicide, theft, aggression, and sexual abuse) .....”); LAW N. VIII: SUPPLEMENTARY NORMS ON CRIMINAL LAW MATTERS (Vatican); LAW N. IX: AmENDMENTS to the Criminal Code AND the Code of Criminal Procedure (Vatican); Apostolic Letter Issued Motu Proprio by Pope Francis on the Jurisdiction of Judicial Authorities of Vatican City State in Criminal Matters, para. 1(b) (July 11, 2013) [hereinafter Apostolic Letter Issued Motu Proprio], https://w2.vatican.va/content/francesco/en/motu_proprio/documents/papa-francescomotu-proprio_20130711_organi-giudiziari.html [https://perma.cc/BN33-Y2XD]. 
nationality law, ${ }^{130}$ health and welfare protections, ${ }^{131}$ and education within the state. ${ }^{132}$ While canon law governs marriage in the Church, the Vatican City has its own distinct laws on marriage registration for civil purposes. ${ }^{133}$ It has corporate law; for example, the Vatican bank is incorporated under Vatican City law as a public foundation. ${ }^{134}$

This legal system is separate from that of the Holy See, ${ }^{135}$ though all "legislative, executive and judicial power" of both systems are ultimately held by the Pope, as a monarchical head of state. ${ }^{136}$ The Vatican City has a number of bodies exclusively for political governance that do not have a role in governing the Church, including a governor, ${ }^{137}$ executive offices, and judicial institutions. ${ }^{138}$ In this way, the Vatican City exercises state jurisdiction. ${ }^{139}$ In addition, the Vatican, not the Holy See, is a member of

130. See Second Reports of States Parties Due in 1997, supra note 16, - 111; List of Issues in Relation to the Second Periodic Report, supra note 9, $₫ 16$.

131. See Second Reports of States Parties Due in 1997, supra note 16, ๆ 113.

132. See id. $\uparrow 114$.

133. See id. $\uparrow 112$.

134. See Agreement Between the United States of America and the Holy See, Acting Also in the Name and on Behalf of the Vatican City State, to Improve International Tax Compliance and to Implement FATCA, U.S.-Holy See, art. 1(n), June 10, 2015, T.I.A.S. No. 15-610 [hereinafter U.S. and Holy See Agreement to Improve Tax Compliance] ("The term 'Reporting HS/VCS Financial Institution' means any HS [Holy See]/VCS Financial Institution that is not a Non-Reporting HS/VCS Financial Institution. The Institute for the Works of Religion (IOR) is a public law foundation under the laws of the Holy See and the Vatican City State and, for purposes of this Agreement, a Reporting HS/VCS Financial Institution.").

135. See Second Reports of States Parties Due in 1997, supra note 16, \ 107; Ryngaert, supra note 16.

136. See Ryngaert, supra note 16, at 834 n.16; HARRIS, supra note 121; CERD, Consideration of Reports 2014, supra note 17, ๆ 13 ("VCS is under the sovereignty of the Roman Pontiff . . . The fullness of legislative, executive and judicial power resides in the Roman Pontiff as Sovereign and Head of State ....").

137. See Holy See: Pope Names New Foreign Minister (Sep. 15, 2006, 11:14 AM), https://wikileaks.org/plusd/cables/06VATICAN198_a.html [https://perma.cc/LLC8-KFQ5] ("Pope Benedict XVI has named Moroccan born archbishop Dominique Mamberti as the Holy See's Secretary for Relations with States (FM equivalent). . . . He replaces Archbishop Giovanni Lajolo who has been appointed as 'Governor' of Vatican City State.”).

138. See Ryngaert, supra note 16.

139. See Agreement for the Application of Safeguards, supra note 48, art. 1 ("The Holy See undertakes ... to accept safeguards . . on all source or special fissionable material in all peaceful nuclear activities within the territory of the Vatican City State, under the jurisdiction of that State or carried out under its control anywhere, for the exclusive purpose of verifying that such material is not diverted to nuclear weapons or other nuclear explosive devices."); id. art. 2 ("The Agency shall have the right and the obligation to ensure that safe guards will be applied ... on all source or special fissionable material in all peaceful nuclear activities within the territory of the Vatican City State, under the jurisdiction of that State or carried out under its control anywhere, for the exclusive purpose of verifying that such material is not diverted to nuclear weapons or other nuclear explosive devices."); id. Protocol, art. I(1) ("Until such time as the Holy See has, in peaceful nuclear activities within the territory of the Vatican City State or under the jurisdiction or control of that State anywhere ...."). 
several international organizations in its own capacity ${ }^{140}$ and has adhered to a number of treaties. ${ }^{141}$

Some authorities deny that the Vatican City is a distinct legal person, ${ }^{142}$ arguing that it is better understood as a province, region or administrative sub-section of the Holy See. ${ }^{143}$ It is true that informally the Holy See and Vatican are often conflated, ${ }^{144}$ even casually in some UN records ${ }^{145}$ and in

140. See, e.g., International Telecommunication Convention, at 245, adopted Oct. 2, 1947, 193 U.N.T.S. 188 (entered into force Jan. 1, 1949). But see European Parliament, Question for Written Answer E-002925/13 to the Commission Saïd El Khadraoui (S\&D), 2014 O.J. (C 6E) 581 [hereinafter Question by Saïd El Khadraoui] ("Neither the Holy See nor the Vatican City State are Member States of the EU.") (emphasis added).

141. See Ryngaert, supra note 16, at 835, 858 ("The Vatican acts internationally in the field of more technical matters ... . This mini-State, however, has a status aparte in international law, as in fact it merely exists as a territorial basis guaranteeing the independence of a non-State actor, the Holy See.") (emphasis in original); see, e.g., Question for Nuno Teixeira, supra note 66 ("The E.U. has a Monetary Agreement with the Vatican City State ....”).

142. See CRAWFORD, supra note 16, at 225; DuURSMA, supra note 25, at 386-87; Arangio-Ruiz, supra note 35, at 354; Concordat Between the Holy See and Spain, supra note 60, art. III(1) ("The Spanish State recognizes the status of international body corporate of the Holy See and Vatican City State.”).

143. See CRAWFORD, supra note 16, at 223; DUURSMA, supra note 25, at 387.

144. See Holy See v. Starbright Sales Enters., Inc., 102 I.L.R. 163, 169 (S.C., Dec. 1, 1994) (Phil.) ("In view of the wordings of the Lateran Treaty, it is difficult to determine whether the statehood is vested in The Holy See or in the Vatican City. . . . The Vatican City fits into none of the established categories of States, and the attribution to it of 'sovereignty' must be made in a sense different from that in which it is applied to other States."); but see List of Issues in Relation to the Second Periodic Report, supra note 9, 17 ("The Holy See is related but separate and distinct from the territory of Vatican City State (VCS), over which the Holy See exercises sovereignty, and the international personality of the Holy See has never been confused with the territories over which it has exercised State sovereignty.").

145. Note that CERD and CRC reports are coded "VAT," presumably for "Vatican," although it is unclear why "Vatican" would be the correct usage because it is not a U.N. Observer nor is it party to those treaties. See, e.g., U.N., Comm. on the Elimination of Racial Discrimination, Concluding Observations on the Combined Sixteenth to Twenty-Third Periodic Reports of the Holy See, I 8, U.N. Doc. CERD/C/VAT/CO/16-23 (Jan. 11, 2016) [hereinafter CERD, Concluding Observations 2016]; see also List of Issues in Relation to the Second Periodic Report, supra note 9. Further, the Holy See uses ".va" as its country-code top-level domain and the Internet Assigned Numbers Authority refers to the Holy See as if it was an alternative name for the Vatican City. See Delegation Record for .VA, INTERNET ASSIGNED NOS. AUTH. (Oct. 14, 2016), https://www.iana.org/domains/root/db/va.html [https://perma.cc/ 5YA6-RBNR] (referring to the Holy See as "Holy See - Vatican City State" and "Holy See (vatican [sic] City State)"). For evidence of its current use, see, e.g., HOLY SEE, https://w2.vatican.va/content/ vatican/en.html [https://perma.cc/35KW-XLWS] (last visited Aug. 31, 2019). Lastly, the International Organization for Standardization uses VA or VAT to designate the Holy See, not the Vatican specifically. See Standard: ISO 3166-Codes for the Representation of Names of Countries and Their Subdivisions, INT'L ORG. STANDARDIZATION [hereinafter Standard: ISO 3166], https://www.iso.org/obp/ ui/\#iso:code:3166:VA [https://perma.cc/MB7F-BQP4] (last visited Aug. 31, 2019) (listing Holy See as "VA" for alpha-2 and "VAT" for alpha-3). Previously the codes were assigned to the "VATICAN CITY STATE (HOLY SEE)," but are now assigned to the "Holy See." Id. Note that the ISO country codes are drafted by a committee that includes the International Atomic Energy Agency (IAEA), International Civil Aviation Organization (ICAO), International Telecommunication Union (ITU), Universal Postal Union (UPU), United Nations Economic Commission for Europe (UNECE), in addition to the Internet Corporation for Assigned Names and Numbers (ICANN) and a number of country specific 
some international court decisions. ${ }^{146}$ Although this casual usage might be more akin to referring to the US President, and the administrative offices surrounding that office, as "the White House,"147 or to the historical reference to the Ottoman Imperial Government as the "Sublime Port."148

For its part, the Holy See objects to its conflation with the Vatican City. ${ }^{149}$ It has consistently asserted the separate and distinct personalities of the Vatican and Holy See as two legal persons. ${ }^{150}$ If indeed the Vatican is an administrative unit - albeit a territorial administrative unit - of the Holy See - a non-territorial entity ${ }^{151}$ — then either the Holy See is a state in the traditional sense, or the Vatican is not a state. Both of these outcomes would be contrary to international practice, and could result in either casting doubt on the Holy See's nature during the years in which it had no territory, or rendering 110 acres in the center of Rome as non-state territory, perhaps terra nullius. The better view, accepted in practice and the literature, is that

standardization organizations. ISO 3166 Country Codes, INT'L ORG. STANDARDiZATION, https:// www.iso.org/iso-3166-country-codes.html [https://perma.cc/3B39-RKXZ] (last visited May 14, 2021).

146. See, e.g., Pellegrini v. Italy, 2001-VIII Eur. Ct. H.R. 369, para. 31 ("Under Article $8 \S 2$ of the Concordat between Italy and the Vatican ....").

147. See, e.g., President Trump and Israeli Prime Minister on Middle East Plan, C-SPAN (Jan. 28, 2020), https://www.c-span.org/video/?468641-1/president-trump-announces-middle-east-peace-plan [https://perma.cc/6RDW-WHPV].

148. See, e.g., Telegram from the Ambassador in Fr. (Sharp) to the Sec'y of State, 796 (May 29, 1915), in PAPERs RELATING TO THE Foreign RELATIONS OF THE United STATES (Supp. 1915) ("In view of these new crimes of Turkey against humanity and civilization, the Allied governments announce publicly to the Sublime Porte that they will hold personally responsible [for] these crimes all members of the Ottoman government and those of their agents who are implicated in such massacres.").

149. See Comments of the Holy See, supra note 28, paras. 3-8; List of Issues in Relation to the Second Periodic Report, supra note 9, $\uparrow \uparrow \mid 6-8$; U.N., Comm. on the Rights of the Child, List of Issues in Relation to the Report Submitted by the Holy See Under Article 12, Paragraph 1, of the Optional Protocol to the Convention on the Rights of the Child on the Sale of Children, Child Prostitution and Child Pornography, Addendum: Replies of the Holy See to the List of Issues, q9 6-8, U.N. Doc. CRC/C/OPSC/VAT/Q/1/Add.1 (Jan. 21, 2014); U.N., Comm. on the Rights of the Child, Consideration of Reports Submitted by States Parties Under Article 12, Paragraph 1, of the Optional Protocol to the Convention on the Rights of the Child on the Sale of Children, Child Prostitution and Child Pornography, Initial Reports of States Parties Due in 2003: Holy See, ๆๆ 4-5, U.N. Doc. CRC/C/OPSC/VAT/1 (Nov. 8, 2012); Second Reports of States Parties Due in 1997, supra note 16, $\mathbf{q}$ 1-5; U.N., Comm. on the Rights of the Child, Consideration of Reports Submitted by States Parties Under Article 8, Paragraph 1, of the Optional Protocol to the Convention on the Rights of the Child on the Involvement of Children in Armed Conflict, Initial Reports of States Parties Due in 2003: Holy See, 1 - 4-5, U.N. Doc. CRC/C/OPAC/VAT/1 (Oct. 22, 2012); Initial Reports of States Parties Due in 1992, supra note 16, $\mathbf{\uparrow \uparrow 1 - 2 . ~}$

150. See List of Issues in Relation to the Second Periodic Report, supra note 9, 17 ; Initial Reports of States Parties Due in 1992, supra note 16, $₫ 1$; CERD, Consideration of Reports 2000, supra note 23, I 4(d); CERD, Consideration of Reports 2014, supra note 17, \9.

151. See Allen D. Hertzke, The Catholic Church and Catholicism in Global Politics, in RouTLEDGE HANDBOOK OF RELIGION AND Politics 36, 38-39, 48 (Jeffrey Haynes ed., 2d ed. 2016). 
the Vatican City is a state. ${ }^{152}$ Thus, within the Holy See-Vatican arrangement there are two distinct international legal persons. ${ }^{153}$

\section{The Holy See is the Sovereign of the Vatican City}

Even if there are two distinct international legal persons, they clearly exist in some kind of relationship. One of the more perplexing questions is the precise nature of this relationship, and indeed courts and other authorities have struggled to understand the arrangement. ${ }^{154}$ The Vatican is certainly not a "normal" state, ${ }^{155}$ and the Holy See itself has argued that it has a special nature. ${ }^{156}$ The Vatican City is "subordinated" to the Holy See; it is not "foreign" to it, ${ }^{157}$ and it is constituted solely to benefit the Holy See, ${ }^{158}$ or as Pope Paul VI stated: it "leave[s] [the pope] free to exercise his spiritual mission and to assure all those who treat with him that he is independent of every worldly sovereignty." 159 In fact, "[i]t is the Pope, as the Head of the Roman Catholic Church and the Head of the Vatican Government, who decides on the hierarchical relation between the Holy See and the Vatican Government." 160 In this way, it is difficult to view the Vatican City as an

152. See Concordat Between the Holy See and Spain, supra note 60, art. III(1); CRAWFORD, supra note 16, at 226-27; DUURSMA, supra note 25, at 387; Arangio-Ruiz, supra note 35 , at 354.

153. See Ciprotti, supra note 34.

154. See, e.g., Dale v. Colagiovanni, 443 F.3d 425, 429 (5th Cir. 2006); O’Bryan v. Holy See, 556 F.3d 361, 369 (6th Cir. 2009) ("The Holy See is both a foreign state and an unincorporated association and the central government of an international religious organization, the Roman Catholic Church. The United States has recognized the Holy See as a foreign sovereign since 1984.").

155. See CRAWFORD, supra note 16, at 223 ("It cannot be denied that the position of the Vatican City is peculiar and that the criteria for statehood in its case are only marginally (if at all) complied with.").

156. See Second Reports of States Parties Due in 1997, supra note 16, 107 ("Any analysis of the law of Vatican City State (VCS) must always be seen in light of its proper nature as acknowledged in the following reservation to the CRC.").

157. See CRAWFORD, supra note 16, at 230 ("[T] he Holy See is not foreign to the Vatican City.").

158. See Holy See v. Starbright Sales Enters., Inc., 102 I.L.R. 163, 169 (S.C., Dec. 1, 1994) (Phil.) (finding that the Vatican City was not meant for normal state purposes, but rather "ecclesiastical purposes and international objects.”); Initial Reports of States Parties Due in 1992, supra note 16, ๆ 1 ("Similarly, its jurisdiction over a territory, known as the Vatican City State, serves solely to provide a basis for its autonomy and to guarantee the free exercise of its spiritual mission."); 2010 Tip Report Input, supra note 125; Special Representative of the City of the Vatican v. Pieciukiewicz, 78 I.L.R. 120, 122 (1982) (It.) ("[T]he Vatican City [is] referred to in legal writings and case-law as a 'State with a purpose'...."); CERD, Consideration of Reports 2000, supra note 23, - 4(c) ("[T] he State of Vatican City. . . . does not contain a civil society but a working community placed temporarily in the service of the Holy See."); CERD, Consideration of Reports 2014, supra note 17, I 11 ("VCS was constituted a State with the Lateran Treaty of 1929 to ensure the Holy See's absolute and evident independence and to guarantee its indisputable inherent sovereignty in the international realm for the accomplishment of its worldwide moral mission ....”).

159. Pope Paul VI, Address to the U.N. General Assembly (Oct. 4, 1965), in 1965 U.N.Y.B. 237, 238, U.N. Sales No. 66.1.1.

160. DUURSMA, supra note 25, at 387; see Morss, supra note 23. 
organic state, arising from the historical process that gave rise to other states. ${ }^{161}$ The Holy See, for its part, only argues that the See is organic ${ }^{162}$ and that the Church and Vatican City have an organic relationship. ${ }^{163}$ Even if we accept the view that the Vatican was established for the functional purpose of ensuring the Holy See's independence, it is unclear whether this functional purpose has any implication for Vatican statehood. ${ }^{164}$ It may be that other states have been constituted for unusual, functional, or even irrational reasons, ${ }^{165}$ but we do not generally inquire into the motivation for state creation as a criterion for the legality, or legal limitations and conditions, of the state.

The better characterization is that the Holy See is a sovereign legal person that governs the state of the Vatican City. ${ }^{166}$ A slightly more nuanced view is that the Holy See is the sovereign of the Vatican City. This view is held by the Holy See ${ }^{167}$ and is affirmed in the Lateran Accords, which grant

161. See Legality of the Threat or Use of Nuclear Weapons, Advisory Opinion, 1996 I.C.J. 66, ๆ 25 (July 8); Reparation for Injuries Suffered in the Service of the United Nations, Advisory Opinion, 1949 I.C.J. 174, 178-79 (Apr. 11).

162. See List of Issues in Relation to the Second Periodic Report, supra note 9, ๆ 6.

163. The Holy See in fact refers to the relationship between VCS and church as "organic," though not the VCS itself. See Second Reports of States Parties Due in 1997, supra note 16, ๆ 108(a) (“Although an intimate organic relationship of VCS with the Catholic Church exists, not every aspect of canon law is applicable in the temporal governance of VCS.").

164. CERD, Consideration of Reports 2000, supra note 23, - 4(e) ("The international personality of the Holy See takes precedence over any territorial personality, as is borne out, for example, by the years 1870-1929 which lay between the loss of the traditional Church States and the establishment of the State of Vatican City. During those sixty years the Holy See continued to act as a subject of international law by concluding concordats and international treaties with a great number of States, participating in international conferences, conducting mediation and arbitration missions, and maintaining both active and passive diplomatic relations."); see also id. ๆ 4(b) (citing 1983 CODE c.361) ("In the internal law of the Catholic Church, the Holy See is defined as the Government of the universal Church composed of the Sovereign Pontiff and of the institutions which proceed from him.").

165. See A Guide to the United States' History of Recognition, Diplomatic, and Consular Relations, by Country, Since 1776: Panama, U.S. DEP'T ST.: OFF. HISTORIAN, https://history.state.gov/ countries/panama [https://perma.cc/95FD-A3Q9] (last visited Jan. 7, 2021) ("The area that became Panama was part of Colombia until the Panamanians revolted, with U.S. support, in 1903. In 1904, the United States and Panama signed a treaty that allowed the United States to build and operate a canal that traversed Panama. The treaty also gave the United States the right to govern a ten-mile wide Canal Zone that encompassed the waterway, which was completed in 1914.").

166. See CRAWFORD, supra note 16, at 230; 2010 Tip Report Input, supra note 125 ("The Holy See, which oversees Vatican City State ....”); Holy See: Muslim Engagement Strategy (Dec. 1, 2006, 5:20 PM), https://wikileaks.org/plusd/cables/06VATICAN248_a.html [https://perma.cc/8HJN-YSJS] ("The Holy See is in effect the central government of the Catholic Church. Its head of state, Pope Benedict XVI, is respected and revered by the world's one billion-plus Catholics and many others ....").

167. See CERD, Consideration of Reports 2000, supra note 23, - 4(c) ("The Holy See is also the sovereign of the State of Vatican City."); CERD, Consideration of Reports 2014, supra note 17, ๆ 8 ("The Holy See also exercises its sovereignty over the territory of Vatican City State (VCS) .....”). But see CERD, Consideration of Reports 2000, supra note 23, ๆ 4(b) (citing 1983 CODE c.361) ("In the internal 
the Holy See "ownership, exclusive and absolute power and sovereign jurisdiction" over the Vatican City. ${ }^{168}$ Crawford compares this governance arrangement to a hypothetical where the UN is granted sovereignty over its headquarters territory in New York. ${ }^{169}$ The UN is already an international legal person, so this grant would simply add a new role for the organization of governing the "UN state." In fact, a variation on Crawford's hypothetical has already happened in the cases of international territorial administration by the UN. For example, the UN has exercised international territorial governance in Eastern Slavonia, ${ }^{170}$ East Timor, ${ }^{171}$ and Kosovo, ${ }^{172}$ among other administrations. ${ }^{173}$ If Vatican City was dissolved, the Holy See would continue to exist. Some departments within the Holy See, pertaining to governance of Vatican City, would undoubtedly be abolished, ${ }^{174}$ but the Holy See would continue to operate in the same form in which it operated after the loss of the Papal States; it would still govern the Church and engage in international relations. In addition, the Holy See's role in conducting

law of the Catholic Church, the Holy See is defined as the Government of the universal Church composed of the Sovereign Pontiff and of the institutions which proceed from him . ....").

168. See Lateran Accords, supra note 9, pmbl. ("[I]t has been deemed necessary to establish the State of the Vatican, and to recognize so far as the latter is concerned, complete ownership, exclusive and absolute power and sovereign jurisdiction on the part of the Holy See . ..."); id. art. 3. ("Italy recognizes full possession and exclusive and absolute power and sovereign jurisdiction of the Holy See over the Vatican, as at present constituted, with all its appurtenances and endowments. Thus the Vatican City is established for the special purposes and with the provisions laid down in the present treaty."); Agreement for the Application of Safeguards, supra note 48, pmbl. ("[T]he Holy See enjoys exclusive sovereignty and jurisdiction over the Vatican City State ....").

169. See CRAWFORD, supra note 16 , at 231 .

170. For background on the United Nations Transitional Authority in Eastern Slavonia, Baranja, Western Sirmium (UNTAES), see U.N. Permanent Representative of Croatia, Letter dated Nov. 15, 1995 from the Permanent Representative of Croatia addressed to the Secretary-General, Annex, Basic Agreement on the Region of Eastern Slavonia, Baranja and Western Sirmium, U.N. Doc. A/50/757 (Nov. 15, 1995); S.C. Res. 1037 (Jan. 15, 1996).

171. For background on the United Nations Transitional Administration in East Timor (UNTAET), see S.C. Res. 1272 (Oct. 25, 1999). See also S.C. Res. 1338, \ 2 (Jan. 31, 2001); S.C. Res. 1392, ๆ 2 (Jan. 31, 2002); S.C. Res. 1410, 1 (May 17, 2002); S.C. Res. 1480, 1 (May 19, 2003); U.N., Transitional Admin. in E. Timor, Reg. No. 1999/2, U.N. Doc. UNTAET/REG/1992/2 (Dec. 2, 1999); U.N., Transitional Admin. in E. Timor, Reg. No. 1999/3, U.N. Doc. UNTAET/REG/1999/3 (Dec. 3, 1999); U.N., Transitional Admin. in E. Timor, Reg. No. 2000/1, U.N. Doc. UNTAET/REG/2000/1 (Jan. 14, 2000); U.N., Transitional Admin. in E. Timor, Reg. No. 2001/1, U.N. Doc. UNTAET/REG/2001/1 (Jan. 31, 2001).

172. For United Nations Mission in Kosovo (UNMIK), see S.C. Res. 1244 (June 10, 1999); U.N., Interim Admin. Mission in Kosovo, Reg. No. 2001/9, U.N. Doc. UNMIK/REG/2001/9 (May 15, 2001).

173. See, e.g., S.C. Res. 814 (Mar. 26, 1993); General Framework Agreement for Peace in Bosnia and Herzegovina, Bosn. \& Herz.-Croat.-Yugoslavia, Dec. 14, 1995, 35 I.L.M. 89; S.C. Res. 1031, ๆ 26 27 (Dec. 15, 1995) (creating the U.N. Office of the High Representative).

174. See CRAWFORD, supra note 16, at 230; DUURSMA, supra note 25 , at 386-87. 
diplomatic relations on behalf of the Vatican City affirms the conclusion that the Holy See is governing the Vatican. ${ }^{175}$

Some authorities conclude that the Pope is the ruler of both the Holy See and the Vatican City. ${ }^{176}$ This view does not accurately describe the Pope's relationship with the Vatican City. The better interpretation, in line with the argument in this article, is that the Holy See is the sovereign, nonterritorial, international legal person that exercises its sovereignty over and governs a state called the Vatican City. The Pope, and certain other entities, are organs of the Holy See that are competent to govern the Vatican. Thus, the Holy See is both the government of the Catholic Church and the sovereign of the Vatican City.

\section{The Holy See is the Party the CRC, Not the Vatican City}

As established above, the Holy See and the Vatican City are distinct persons in an unusual relationship where the Holy See is an international legal person acting as sovereign of another international person, the Vatican City. We next consider which of those two entities has adhered to the CRC. Identifying which entity is responsible under the CRC depends on which entity is bound to it.

\section{Separate Treaty Adherence by the Holy See and Vatican City}

The Holy See and the Vatican City are two distinct international legal persons that are capable of entering into international agreements in their own right. Both legal persons exercise this right. The Holy See very clearly understands the distinction between treaties that bind it and treaties that bind the Vatican City. For example, the Vatican is party to a number of treaties, ${ }^{177}$

175. See CRAWFORD, supra note 16, at 226-30; Ryngaert, supra note 16; GERD WESTDICKENBERG, Holy SEE paras. 10-11, Max Planck Encyclopedias of International Law (database updated June 2006).

176. See U.S. Relations with the Holy See, supra note 37 ("The Pope is the ruler of both Vatican City State and the Holy See."); see also Agreement for the Application of Safeguards, supra note 48 ("[T]he Holy See enjoys exclusive sovereignty and jurisdiction over the Vatican City State, of which the Roman Pontiff is the sovereign ....").

177. See, e.g., IAEA Statute Ratification, supra note 68; Amendment to IAEA Statute, supra note 68; International Wheat Agreement of 1956, opened for signature Mar. 23, 1956, 270 U.N.T.S. 103 [hereinafter Wheat Agreement 1956]; Protocol for the Extension of the International Wheat Agreement, opened for signature Mar. 22, 1965, 604 U.N.T.S. 378 [hereinafter Protocol for the Extension of the International Wheat Agreement]; Convention on the Recovery Abroad of Maintenance, opened for signature June 20, 1956, 268 U.N.T.S. 3 (entered into force May 25, 1957) [hereinafter Convention on the Recovery Abroad of Maintenance]; Exchange of Notes Constituting an Agreement Concerning Tax Exemptions for Diplomatic Agents of Italian Nationality Accredited to the Holy See by Other States, Holy See-It., Dec. 16, 1955, 260 U.N.T.S. 319; International Convention on Certain Rules Concerning Civil Jurisdiction in Matters of Collision, opened for signature May 10, 1952, 439 U.N.T.S. 217 (entered into force Nov. 20, 1955); Agreement Concerning Subscriptions to Newspapers and Periodicals, opened for signature July 10, 1964, 613 U.N.T.S. 193; Exchange of Notes Constituting an Agreement Concerning 
yet at other times, the party is the Holy See. ${ }^{178}$ Clearly, the Holy See has the authority to alternatively act "in the name and on behalf of the Vatican City State," 179 or in its own name, when it chooses to do so.

Some authorities have concluded that regardless of whether the party is the Holy See or Vatican City, the real party is substantively always the Holy See. ${ }^{180}$ One could interpret that where the Vatican appears to have adhered to a treaty, in fact the Holy See has adhered, but has limited the treaty's scope of application to the Vatican City territory. It is true that the Holy See has adhered to treaties that are, by their express terms, only open to "states," and this could suggest that Vatican would be the party in such cases, as it is a state and the Holy See is not.

First, this interpretation has not been supported by practice. The Holy See has been held to be competent to enter into treaties prior to the constitution of the Vatican City in 1929. ${ }^{181}$ This practice suggests that the Holy See knows that it is an international legal person, distinct from the Vatican, and capable of entering into treaties in its own name. ${ }^{182}$ As mentioned above, the Vatican City has been identified as the party in a number of treaties; it appears to have a treaty making capacity distinct from that of the Holy See. Furthermore, the Holy See can enter into treaties in its own name and in the name of the Vatican City State concurrently. ${ }^{183}$ In such cases, the Holy See has used the designation "HS/VCS" to identify the dual

the Establishment of a Military Vicariate in the Armed Forces of the Philippines, Phil.-Vatican., June 18, 1952, 543 U.N.T.S. 165 [hereinafter Establishment of a Military Vicariate with the Philippines].

178. See Exchange of Notes Constituting an Agreement ("Vatican City Agreement") in Relation to the Extension of the General Treaty of 5 April 1972 on the Judicial Settlement of Disputes Between the Republic of Chile and the Argentine Republic, Sept. 10, 1982, 1292 U.N.T.S. 201; Agreement Concerning Military Jurisdiction and Religious Assistance to the Armed Forces, Holy See-Spain, Aug. 5, 1950, 1219 U.N.T.S. 35; Agreement Concerning Economic Matters, supra note 48; Agreement Concerning the Application of the Corporation Tax to Ecclesiastical Entities, Elaborated by the Spanish Church-State Technical Commission Complementing the Agreement Between the Spanish State and the Holy See Concerning Economic Matters, Holy See-Spain, Oct. 10, 1980, 1319 U.N.T.S. 315; Convention on the Recognition and Enforcement of Foreign Arbitral Awards, opened for signature June 10, 1958, 330 U.N.T.S. 3 (entered into force June 7, 1959); Universal Copyright Convention, opened for signature Sept. 6, 1952, 216 U.N.T.S. 132.

179. Agreement for the Application of Safeguards, supra note 48, pmbl.

180. See Gaetano Arangio-Ruiz, supra note 35, at 367 ("The Holy See . . . may well in given areas of its international relations prefer to operate through the Vatican City. The Vatican City appears in fact formally the party also in some multilateral instruments of a technical nature ... . It seems obvious ... that the acting or contracting party is always, from the viewpoint of general international law, the Holy See (or the Roman Church).”).

181. See CRAWFORD, supra note 16 , at 226.

182. See Bundesverfassungsgericht [BVerfG] [Federal Constitutional Court] Mar. 26, 1957, 19 I.L.R. 592 (Ger.).

183. See, e.g., U.S. and Holy See Agreement to Improve Tax Compliance, supra note 134. 
nature of the parties. ${ }^{184}$ In all of the preparatory works, adherence documents, and references in subsequent practice, the Holy See is expressly mentioned as the party. ${ }^{185}$ The Holy See's status as a party to a treaty has been consistently upheld as valid, without any objections. ${ }^{186}$ The Holy See is party to treaties that are only open to "states" even though the Holy See itself is not a "state." In these cases, the better interpretation would be that the states parties have chosen to apply a very liberal meaning of "state" 187 that permits the Holy See to participate. This liberal approach would be consistent with other situations. For example, the Holy See is admitted as an observer at the UN as a non-member "state." "188 The UN has simply chosen to treat the Holy See as if it were a state for the purpose of observer status. Thus, practice has consistently affirmed that we do not substitute one party for another.

Second, the practice of replacing the formal designation of a party to a treaty with a substantive one does not apply when two distinct legal persons are involved. For example, when a head of state adheres to a treaty, we understand that the individual is binding the state, not himself or herself personally. However, when locating the substantive party to the treaty, the formally designated party tends to at least be an organ of the substantive one, ${ }^{189}$ and not an entirely separate international legal person. Simply

184. See id. art. 1(1)(d) ("The term 'HS/VCS' means Holy See, acting also in the name and on behalf of the Vatican City State.").

185. See, e.g., supra notes 47-53.

186. See id.

187. See, e.g., Gerald G. Fitzmaurice, Law of Treaties: Report by Sir Gerald Fitzmaurice, Special Rapporteur, [1956] 2 Y.B. Int'l L. Comm'n 104, 118, U.N. Doc A/CN.4/101 (“[E]ntities [may be] recognized as being States on special grounds ... this would include the Vatican State.") (internal quotation marks omitted). Compare this liberal interpretation of the terms of treaties being limited to "states," to the controversy over whether Palestine can be considered a state for purposes of some of the same treaties. See Dapo Akande, Palestine as a UN Observer State: Does this Make Palestine a State, EJIL: TALK! (Dec. 3, 2012), https://www.ejiltalk.org/palestine-as-a-un-observer-state-does-this-makepalestine-a-state/ [https://perma.cc/FET7-ZR9T]. It is perhaps remarkable that this author could find no objections to this practice concerning the Holy See.

188. See Non-Member-States, UNITED NATIONS, https://www.un.org/en/about-us/non-memberstates [https://perma.cc/6EHX-YYM2] (last visited Jan. 18, 2021) ("Non-member States having received a standing invitation to participate as Observers in the sessions and the work of the General Assembly and maintaining Permanent Observer Missions at Headquarters."); see also William Thomas Worster, The Exercise of Jurisdiction by the International Criminal Court over Palestine, 26 AM. U. INT'L L. REV. 1153, 1181-88 (2011) (documenting the widespread practice of liberally interpreting the term "state" for purposes of treaty adherence); Worster, Territorial Status Triggering a Functional Approach to Statehood, supra note 59; Worster, Functional Statehood in Contemporary International Law, supra note 58.

189. See Treaty on European Union, pmbl., tit. I, art. A, July 29, 1992, O.J. (C 191) 1 [hereinafter The Maastricht Treaty] ("H[is] M[ajesty the] K[ing of the] B[elgians], H[er] M[ajesty the] Q[ueen of] $\mathrm{D}$ [enmark] ... . [have decided] to establish a European Union .... [b]y this Treaty, the High Contracting Parties establish among themselves a European Union ...."). The monarch is not a distinct legal person on the international plane from the state of which his or her office is an organ. 
substituting one international legal person for another, even if there is an overlapping governance structure, as party to a treaty is far beyond traditional concepts of consent. ${ }^{190}$ To illustrate this departure from traditional concepts, consider, for instance, if UNMIK entered into a treaty and we subsequently argued that the UN was now the party or if the President of France consented to a treaty in his capacity as Co-Prince of Andorra and we argued that the French State is now bound. In keeping with the Holy See's vigorous assertion that it is a legal person separate from the Vatican City, it would be quite surprising to substitute one entity for the other. Therefore, we must take the choice of entity seriously and follow the formal designation.

All that being said, it is sometimes difficult to determine when the Holy See acts in its capacity as an international legal person or as the governing authority of the Vatican City State. ${ }^{191}$ However, we can take some steps to identify which entity is the party. On occasion, the Holy See will enter a reservation or make a declaration limiting application to the Vatican, ${ }^{192}$ or conversely affirm that the treaty applies to the Holy See. ${ }^{193}$ Yet at other times, it enters no communication. ${ }^{194}$ In some of these cases, the subject matter of

190. Cf. Case T-192/16, N.F. v. Council, ECLI:EU:T:2017:128, para. 69 (Feb. 28, 2017) (finding that the EU-Turkey agreement was actually an agreement between Turkey and the Member States of the EU, not with the EU itself, despite overlapping competences).

191. See Henri De Riedmatten, The Part Played by the Holy See in International Organizations, 8 CONCILIUM 74, 83 (1970) (quoting Dag Hammarskjold, Secretary General of the U.N.) ("When I request an audience from the Vatican, I do not go to see the King of the Vatican City but the Head of the Catholic Church.").

192. See Convention on Prohibitions or Restrictions on the Use of Certain Conventional Weapons Which May be Deemed to be Excessively Injurious or to Have Indiscriminate Effects, at 220, opened for signature Oct. 10, 1980, 1342 U.N.T.S. 137 (entered into force Dec. 2, 1983); Status of the Convention on Prohibitions or Restrictions on the Use of Certain Conventional Weapons Which May Be Deemed to Be Excessively Injurious or to Have Indiscriminate Effects (with Protocols I, II and III), UNITED NATIONS TREATY COLLECTION, https://treaties.un.org/Pages/ViewDetails.aspx?src=TREATY\&mtdsg no=XXVI -2\&chapter=26\&clang=_en [https://perma.cc/AH5Z-3UHP] (last visited Feb. 22, 2021) ("The Holy See, as a signatory of the [said Convention and annexed Protocols], in keeping with its proper nature and with the particular condition of Vatican City State, intends to renew its encouragement to the International Community to continue on the path it has taken for the reduction of human suffering caused by armed conflict.").

193. See Montreal Protocol on Substances that Deplete the Ozone Layer, at 89, opened for signature Sept. 16, 1987, 1522 U.N.T.S. 3 (entered into force Jan. 1, 1989); Status of the Montreal Protocol on Substances that Deplete the Ozone, United NATIONS TREATY COLLECTION, https://reaties.un.org/ pages/ViewDetails.aspx?src=TREATY\&mtdsg_no=XXVII-2-a\&chapter=27\&clang=_en $[\mathrm{https}: / /$ perma .cc/FMV2-RCXK] (last visited Feb. 24, 2021) ("In conformity with its own nature and with the particular character of Vatican City State, the Holy See, by means of the solemn act of accession, intends to give its own moral support to the commitment of States to the correct and effective implementation of the Treaties in question and to the attaining of the mentioned objectives.").

194. See Grains Trade Convention of 1995, at 296, opened for signature Dec. 7, 1994, 1882 U.N.T.S. 195 (entered into force July 1, 1995) [hereinafter Grains Trade Convention] (adhering as Holy See without reservation); United Nations Convention on the Carriage of Goods by Sea, at 131, opened for signature Mar. 31, 1978, 1695 U.N.T.S. 3 (entered into force Nov. 1, 1992) [hereinafter United Nations 
the treaty does not appear to have any possible application to a nonterritorial, sovereign entity, and would only have relevance for a territorial state. ${ }^{195}$ This is the case, for example, with the Road Traffic Convention ${ }^{196}$ and the Refugee Convention, ${ }^{197}$ because a non-territorial entity such as the Holy See cannot possibly have road traffic or refoule refugees from its territory.

At this point, we need to distinguish between an entity being a party to a treaty and the scope of application of a treaty. When the British Crown, acting in that capacity, consents to be bound to an international agreement, ${ }^{198}$ we do not imagine that Canada, Australia, and New Zealand are also bound, even though the same individual is the monarch in those states. In those cases, the Crown will designate in what capacity, and by right of which dominion, it acts. The formal designation of capacity informs us of which international legal person is bound. Thus, if Queen Elizabeth II acts by right of Canada, then we know that it is Canada that is bound. In a similar way, the Holy See usually informs the other parties of whether it is acting in its own capacity or as the sovereign of the Vatican City. This question of identity of the party is therefore primarily concerned with which state remains responsible under international law for compliance with the treaty. ${ }^{199}$ It is perhaps good to recall the consistent practice of the Holy See to reaffirm that it is the party to many of these treaties in its own sovereign capacity. Only in cases where the party to the treaty is the Vatican City (or

Convention on the Carriage of Goods by Sea] (adhering as Holy See without reservation); Convention on the Territorial Sea and the Contiguous Zone, at 260, opened for signature Apr. 29, 1958, 516 U.N.T.S. 205 (entered into force Sept. 10, 1964) [hereinafter Convention on the Territorial Sea and the Contiguous Zone] (adhering as Holy See without reservation); Status of the Convention on Road Traffic, UNITED NATIONS TREATY COLLECTION [hereinafter Status of the Convention on Road Traffic], https://treaties.un.org/pages/ViewDetailsIII.aspx?src=TREATY\&mtdsg_no=XI-B-19\&chapter=11\&Te $\mathrm{mp}=$ mtdsg3\&clang=_en [https://perma.cc/H946-EREQ] (last visited Mar. 30, 2021) (adhering as Holy See without reservation); International Convention on the Elimination of All Forms of Racial Discrimination, opened for signature Mar. 7, 1966, 660 U.N.T.S. 195 (entered into force Jan. 4, 1969) [hereinafter Convention on the Elimination of Racial Discrimination] (adhering as Holy See without reservation); UNCAT, supra note 55.

195. See, e.g., United Nations Convention on the Carriage of Goods by Sea, supra note 194; Convention on the Territorial Sea and the Contiguous Zone, supra note 194.

196. See Status of the Convention on Road Traffic, supra note 194; Convention on Road Traffic, at 98, opened for signature Sept. 19, 1949, 125 U.N.T.S. 3 (entered into force Mar. 26, 1952) (adhering as Holy See without reservation, though it is not entirely clear if the party is the Holy See because the signature page is omitted from the treaty series record and the U.N. Secretary General lists the party as the Holy See).

197. See 1951 Refugee Convention, supra note 50, at 191 (adhering as Holy See).

198. See The Maastricht Treaty, supra note 189 (noting that the sovereign of the United Kingdom is a party to the Treaty on European Union).

199. See JAMES CRAWFord, The InTERnATIONAL LAW COMMission's ARticles on State RESPONSIBILITY: INTRODUCTION, TEXT AND COMMENTARIES 77 (2002). 
the Holy See acting on behalf of the Vatican City), would that state be responsible for violations of the treaty.

The second issue after the identity of the party is the scope of application of a treaty. If the Vatican is the party, then the presumption-in line with the Vienna Convention on the Law of Treaties ${ }^{200}$ — is that the treaty applies to the entirety of that state's territory, unless the scope of application is expressly otherwise limited to exclude certain places. If the Holy See is the party, then a similar presumption would apply, as the Holy See never entered any reservation in the Vienna Convention to the default rule on scope of application. However, the Holy See has no territory. Nonetheless, its adherence must have some application. The presumption would therefore not be a presumption of territorial scope, but of jurisdictional scope. In some of the treaties to which the Holy See is party, it has included a declaration on the scope of application concerning the Vatican City. ${ }^{201}$ At first glance, this practice might appear to be in conflict. If the Holy See is the party, and not the Vatican City, then there should be no question of the scope of application concerning the Vatican City. However, upon closer examination, it is possible to make sense of this practice. In the full scope of the Holy See's activities globally, it engages in a wide range of actions, one of which is governing another international legal person, i.e. Vatican City. The presumptive scope of treaty application would mean that the Holy See would be bound to the treaty's terms for its worldwide activities, including taking measures to govern another legal person. While the Vatican City is itself not bound, and thus would never be responsible under international law for violations, the Holy See is. Thus, when the Holy See becomes a party to a treaty, and excludes application to the Vatican City, it must be that the full range of the Holy See's global activities remains subject to the terms of the treaty, exempting only its Vatican City governance measures. In the reverse scenario, when the Holy See adheres to a treaty in its own right, and excludes application to its worldwide activities, aside from governance of the Vatican City, then the Holy See is only bound to govern the state in compliance with the terms of the treaty.

This formal approach can lead to some curious results. For example, the Holy See bound the Vatican to the Brussels Postal Convention, ${ }^{202}$ but then

200. NB To which the Holy See is a party. But see Status of the VCLT, supra note 58 (displaying that the Holy See, not the Vatican, is party to the Vienna Convention).

201. See Status of the Convention Relating to the Status of Refugees, UNITED NATIONS TREATY COLLECTION, https://treaties.un.org/Pages/ViewDetailsII.aspx?src=TREATY\&mtdsg_no=V-2\&chapter $=5 \&$ Temp=mtdsg2\&clang=_en [https://perma.cc/UZK6-2AN3] (last visited Feb. 28, 2021) ("[T]he application of the Convention must be compatible in practice with the special nature of the Vatican City State ...."); 1951 Refugee Convention, supra note 50.

202. Ratification of UPC, supra note 69. 
adhered in its own capacity to the 1964 Vienna Postal Convention. ${ }^{203}$ It bound the Vatican to the International Wheat Agreement, ${ }^{204}$ but then adhered to the International Grains Convention as the Holy See. ${ }^{205}$ Even more remarkable, the annex attached to the International Grains Convention lists the "Vatican City" as a participant. ${ }^{206}$ It can be even more confusing. In some cases, the Holy See entered into a treaty as one entity and ratified an amendment to the treaty as the other, such as in the cases of the IAEA ${ }^{207}$ and UPU. ${ }^{208}$ This would suggest that the Vatican and the Holy See would both be parallel members of the UPU and IAEA, if the original treaty was not implicitly terminated upon its amendment. In all of these cases, however, it is still possible to formally distinguish between the entity that is party to the treaty, and thus responsible, from the scope of application of the treaty.

The reason for the Holy See to act through one or the other legal person might not be transparent. One possibility is that the Holy See might need to bind the Vatican when other treaty partners do not recognize the Holy See as an international legal person, but might recognize the Vatican as a state. To date, no state has formally recognized the Vatican as a state while at the same time denied recognition to the Holy See, ${ }^{209}$ but this practice might be applicable informally. Another possibility is that the Vatican City is chosen as the party in cases where the subject matter is temporal and pertains to territorial governance. This argument, however, is not wholly convincing, because the Holy See often adheres in its own right to temporal agreements on very mundane matters that could only be discharged by a territorial entity,

203. Ratification of UPU Constitution, supra note 69.

204. Wheat Agreement 1956, supra note 177.

205. Grains Trade Convention, supra note 194.

206. Grains Trade Convention, supra note 194, Annex, pt. A ("Votes under Article 11 (from 1 July 1995 to 30 June 1998), Part A . . . V Vatican City ....”).

207. IAEA Statute Ratification, supra note 68; Amendment to IAEA Statute, supra note 68.

208. Ratification of UPC, supra note 69, Agreement Concerning Insured Letters and Boxes, opened for signature July 11, 1952, 186 U.N.T.S. 358; Agreement Concerning Postal Parcels, opened for signature July 11, 1952, 186 U.N.T.S. 360; Agreement Concerning Postal Money Orders and Postal Travellers' Cheques, opened for signature July 11, 1952, 186 U.N.T.S. 362; Agreement Concerning Transfers to and from Postal Cheque Accounts and Supplement Dealing with the Negotiation Through Postal Cheque Accounts of Securities Made Payable at Postal Cheque Offices, opened for signature July 11, 1952, 186 U.N.T.S. 364; Agreement Concerning Cash-On-Delivery Items, opened for signature July 11, 1952, 186 U.N.T.S. 366; Agreement Concerning the Collection of Bills, Drafts, etc., opened for signature July 11, 1952, 186 U.N.T.S. 368; Agreement Concerning Subscriptions to Newspapers and Periodicals, opened for signature July 11, 1952, 186 U.N.T.S. 370; Ratification of UPU Constitution, supra note 69 , at 368,370 .

209. Other authors are invited to examine various recognition statements more carefully to challenge this statement. 
and then limits application to its governance of the state. ${ }^{210}$ Ryngaert explains the distinction in practice as reserving technical matters for the Vatican and worldly, spiritual or human rights issues for the Holy See, though he admits this is not an absolute explanation. ${ }^{211}$ Murphy takes a slightly different view and argues that the Holy See is the party for "major" agreements while the Vatican is used for "service oriented contracts." 212 Crawford, on the other hand, could find no consistent reasoned practice. ${ }^{213}$ Notwithstanding the opacity of these choices, the Holy See does continue to assert the significant and important difference between the two international legal persons, so we can only understand that the choice to act as the Holy See or to act as the sovereign of the Vatican City is a deliberate choice, although the reasons are unclear.

2. Evidence of the Holy See as the Party to the CRC

Following from the above, there are two distinct international legal persons, one acting as sovereign of the other, and both having treaty capacity, which means we need to determine which entity is the party to the CRC. All of the formalities and practice in connection with this treaty point to the Holy See as the party. Other states parties also consider the Holy See to be the party. The Holy See signed and ratified the CRC on April 20, 1990, meaning it was one of the first twenty parties that adhered to it. The CRC is only open to participation by states. ${ }^{214}$ During the negotiations, no state questioned whether it was appropriate for the Holy See to participate, or at least the matter is not mentioned in the drafting history. ${ }^{215}$ In fact, the Holy See was an early and enthusiastic participant in the discussions, ${ }^{216}$ so the silence surrounding its participation, or any unique ways the convention might apply to this sui generis non-territorial entity, is telling. Similarly, no state objected to the participation of the Holy See at the time of signature or ratification. ${ }^{217}$

210. Wheat Agreement 1956, supra note 177; Protocol for the Extension of the International Wheat Agreement, supra note 177; Convention on the Recovery Abroad of Maintenance, supra note 177.

211. See Ryngaert, supra note 16.

212. See Francis X. Murphy, Vatican Politics: The Metapolitique of the Papacy, 19 CASE W. RES. J. INT'L L. 375, 378 (1987).

213. See CRAWFORD, supra note 16 , at 230.

214. See Convention on the Rights of the Child, supra note 1, arts. 46, 49(2), 51(1), 52 (making reference to "states" as the only entities that may adhere to the Convention).

215. See, e.g., SHARON DETRICK, A COMMENTARY ON THE UNITED NATIONS CONVENTION ON THE Rights OF THE CHILD 13 (1999).

216. See id.; Sharon Detrick, Compilation of the Travaux Préparatoires, in THE United NATIONS CONVENTION ON THE RightS OF THE CHILD: A Guide TO THE “TRAVAUX PRÉPARATOIRES” 31, 102-03 (Sharon Detrick ed., 1992) (highlighting that the Holy See actively participated in the sessions of the Working Group responsible for drawing up the text of the convention).

217. See Convention on the Rights of the Child, supra note 1; Status of the CRC, supra note 3. 
It is certainly open to treaty participants to object to the nature and/or personality of another treaty participant. ${ }^{218}$ In light of the lack of any evidence to the contrary, we must conclude that the other negotiating states found the Holy See's participation and adherence unremarkable. This fits with the usual practice of liberally interpreting the term "state" to account for the participation of the Holy See. Thus, before considering any reservations or special terms in the text concerning the scope of the treaty's application, it appears that the other parties understood that the Holy See would be bound to the Convention in the same way that a state would.

The Holy See also considered itself to be the party bound to the CRC. Nowhere in the record does the Holy See communicate that it was only binding its territorial administration in the Vatican City or otherwise exercising the Vatican's treaty making capacity. In fact, the reverse is true. The Holy See has consistently asserted that it is the See that is bound to the treaty. ${ }^{219}$ On April 20, 1990, Renato Martino, a Cardinal and the Permanent Observer of the Holy See to the UN, ${ }^{220}$ signed on behalf of the See before it ratified the Convention. It is important to note that when it adhered to the Convention, it did so "In the name of the Holy See." ${ }^{.21}$ In its second periodic report to the Committee on the Rights of the Child, the Holy See stated:

When the Holy See ratifies or accedes to an international agreement following international law and practice, it also manifests its moral authority and thereby encourages States to ratify the treaty and to accomplish their respective obligations. Indeed, within the international community the Holy See disseminates teachings about moral principles founded upon right reason which are addressed to the whole of mankind and not to Catholic believers alone. ${ }^{222}$

Thus, the Holy See has established itself as bound to the treaty. Had it simply ratified the Convention in order to incur international obligations regarding children's rights in the Vatican City, then it would have either (1) expressly ratified the Convention in right of or on behalf of the Vatican City, or (2) it would have argued that it was only binding itself insofar as its Vatican City governance activities were concerned.

218. Several states have long-standing practices of objecting to the State of Israel participating in any of the treaties to which those states become party. See, e.g., Status of the VCLT, supra note 58 (noting objections by Algeria, Kuwait, Morocco, and Syrian Arab Republic).

219. See List of Issues in Relation to the Second Periodic Report, supra note 9, ๆ 6.

220. See MARTINO Card. Renato Raffaele, Holy SEE, https://press.vatican.va/content/salastampa/ en/documentation/cardinali_biografie/cardinali_bio_martino_rr.html [https://perma.cc/YRL4-FAA2] (last visited June 19, 2019).

221. Convention on the Rights of the Child, supra note 1, at 140.

222. See Second Reports of States Parties Due in 1997, supra note 16, ๆ 5. 
In addition, in its reservations and declarations, the Holy See did not attempt to alter the identity of the treaty party. ${ }^{223}$ It entered three reservations and one declaration. ${ }^{224}$ Two of the reservations pertain to obligations irrelevant for this article. The third reservation, however, commented on the special nature of the Holy See. ${ }^{225}$ Specifically, the reservation stated:

that the application of the Convention be compatible in practice with the particular nature of the Vatican City State and of the sources of its objective law (Art. 1, Law of 7 June 1929, n. 11), and, in consideration of its limited extent, with its legislation in the matters of citizenship, access and residence. ${ }^{226}$

It did not, however, state that the Vatican was the true party to the treaty. Instead, it only limited the application of the treaty's terms when they were applied to the Vatican City. In fact, in its declaration, the Holy See affirmed that it was the party:

By acceding to the Convention on the Rights of the Child, the Holy See intends to give renewed expression to its constant concern for the wellbeing of children and families. In consideration of its singular nature and position, the Holy See, in acceding to this Convention, does not intend to prescind in any way from its specific mission which is of a religious and moral character. ${ }^{227}$

All of these communications were made in the name of the Holy See, ${ }^{228}$ and in the case of the latter declaration, it specifically references the application of the Convention to the Holy See. No state objected to any of these communications.

Even if we stretched the meaning of this reservation to substitute the Vatican City as the party, despite all evidence to the contrary, we face various interpretive problems. The argument could be made that in entering this reservation to the CRC, the Holy See either did not bind itself or excluded the application of the CRC to the Holy See. The first option is untenable because the Holy See consented to the CRC in accordance with its terms and generally under the terms of the Vienna Convention. The second option requires that we read the language of "specific mission" as somehow exempting the Holy See from compliance with the obligations of the treaty.

223. Convention on the Rights of the Child, supra note 1, at 175-77; Status of the CRC, supra note 3.

224. Convention on the Rights of the Child, supra note 1, at 175-77; Status of the CRC, supra note 3.

225. Convention on the Rights of the Child, supra note 1, at 176; Status of the CRC, supra note 3.

226. Convention on the Rights of the Child, supra note 1, at 176; Status of the CRC, supra note 3.

227. Convention on the Rights of the Child, supra note 1, at 176-77; Status of the CRC, supra note 3; see also List of Issues in Relation to the Second Periodic Report, supra note 9, ๆף 6-7.

228. Convention on the Rights of the Child, supra note 1, at 175-77; Status of the CRC, supra note 3 . 
The term "specific mission" was the only text in the reservation that appeared to limit its adherence. This option is untenable for two reasons. Such a reservation potentially violates the object and purpose of the Convention and would thus be invalid, resulting in the Holy See not being a party. Even if not rising to the level to render the reservation invalid, such a reading would still exempt the party from all of its obligations under the treaty, rendering its participation meaningless, which finds no basis in international law or the normal rules of statutory construction.

Another argument could be that, although the Holy See is the formal party, the party actually bound is the Vatican City State. In order to reach this conclusion, we would somehow have to understand the terms "specific mission" or "nature and position" to refer to the separate and distinct international legal persons. This conclusion cannot be correct. The Holy See, as demonstrated, can act solely in the name of the Vatican City and can specifically bind that entity when desired. Because it chose to use the legal person of the Holy See as the party, and in line with its consistent practice prior to adhering to the CRC, we must presume that that is the party that was intended to be bound. Furthermore, the Holy See could have clearly designated the party in a reservation, yet it did not. In referring to its reservation in a report to the CommRC in 2014, the Holy See reaffirmed that it was the party that had adhered to the CRC with the "specific mission" and "nature and position" conditions. ${ }^{229}$ The Holy See has consistently maintained the position that it is bound to the CRC. ${ }^{230}$ In addition, it has accepted that the CRC applies to the See's diplomatic, priestly personnel, ${ }^{231}$ who operate to both govern the church and engage in international relations. It also submits information on its worldwide religious activities as evidence of compliance with the CRC. ${ }^{232}$ Thus, we cannot read the reservation to designate an entirely different international legal person than the Holy See.

Yet another counter-argument could be that both the Holy See and the Vatican City State are bound to the CRC. In one communication with the CRC, the Holy See accepted the finding of the Committee that the Holy See was a party as both an international legal person and as government of the

229. See List of Issues in Relation to the Second Periodic Report, supra note 9, ๆ 6.

230. See Comments of the Holy See, supra note 28, para. 1 ("The Holy See is well aware of its position within the international juridical system, as a sovereign subject of international law, as well as of its obligations as a State Party to the Convention on the Rights of the Child (CRC) and its Optional Protocols, which has been clearly articulated in its Reports, Written Replies and statements made during the inter-active dialogue.") (emphasis in original).

231. See id. para. 3 ("Therefore, the obligations of the Convention and its Optional Protocols refer to Vatican citizens, as well as, where appropriate, the diplomatic personnel of the Holy See or its Officials residing outside the territory of Vatican City State.").

232. See discussion infra Section III.B.2. 
Vatican City. ${ }^{233}$ Certainly, if the Holy See is bound in its individual capacity, then it would be quite difficult for it to administer the Vatican City State in a way that contradicted the $\mathrm{CRC}$, so having both entities as a party might not add more. A discussion on this question is not necessary because if both entities are bound, then the Holy See is necessarily bound, and the analysis remains the same.

The argument above has concluded that the reservation cannot be read to substitute the Vatican City for the Holy See as the party. Thus, adherence with the reservation means that the Holy See is indeed the party to the CRC, and is bound in the scope of its activities as an international legal person and government. It is the opinion of this author that only the Holy See is bound, not the Vatican City State, based on the literal terms of the adherence, reservation and subsequent communications.

As a final observation, the argument above does not mean that the CRC applies to the Church, i.e. to Roman Catholic communities throughout the world. While the Holy See is bound, the Church is not. This distinction means that Catholic doctrine is not bound to comply with the CRC, but instead the temporal activities of the Holy See are. The Holy See was careful to observe that its accession to a treaty is the accession of the international legal person, not that of the Catholic Church as a community of faith, assuming that such an entity could be a party to a treaty. ${ }^{234}$ It was argued above that the Church is not the same as the Holy See. The Holy See is the government of the Church and has international legal personality. The Church does not have international legal personality and could not be a party to a treaty. International law would need to be significantly revised to reach the conclusion that human rights obligations bind an international person's moral convictions and intimate decision on faith. ${ }^{235}$ However, the Holy See

233. See Comments of the Holy See, supra note 28, para. 4 (quoting Concluding Observations of the Second Periodic Report, supra note 4, 9) ("In light of the above, the Holy See takes note with satisfaction that the Committee has considered this position, indicating that it is 'aware' of 'the Holy See's ratification of the Convention as the Government of the Vatican City State, and also as a sovereign subject of international law having an original, non-derived legal personality independent of any territorial authority or jurisdiction' ....") (emphasis in original).

234. See List of Issues in Relation to the Second Periodic Report, supra note 9, 98.

235. Compare along similar lines that the Helsinki Final Act did not require the USSR to renounce communism or even alter its political views on the correct allocation of the means of production, but rather simply provided for certain practices. See Org. for Sec. \& Co-operation in Eur. [OSCE], Helsinki Final Act, at 2, 4 (Aug. 1, 1975), https://www.osce.org/helsinki-final-act [https://perma.cc/L4U2-8QQE]. That being said, whether an international legal person holds a right to religion is debatable at best as such rights accrue only to humans under international law. See generally International Covenant on Civil and Political Rights, opened for signature Dec. 19, 1966, 999 U.N.T.S. 171 [hereinafter ICCPR] (noting the various individual rights, including the right of self-determination and the freedom to pursue cultural and social development, protected by signatories of the agreement). 
is bound, including its worldwide activities, which in turn includes its governance of both the Church and the Vatican City.

\section{THE JURISDICTION OF THE HOLY SEE}

Having determined that the Holy See is bound to the CRC, we next need to consider whether the Holy See exercises jurisdiction in the same sense as states, and when it would incur any responsibility for violations of the CRC. As a non-territorial, unusual entity that also participates in international relations as an international legal person, the Holy See does not easily fit into the usual paradigms of state compliance with international law. The key threshold requirement for the application of human rights norms is that a state only needs to comply with human rights obligations where it has jurisdiction. But for the Holy See, it is unclear if, when, and how it exercises jurisdiction in the same way as a state.

The CRC, like other human rights treaties, applies to activities within the state's "jurisdiction." Specifically, the CRC uses the following formula:

States Parties shall respect and ensure the rights set forth in the present Convention to each child within their jurisdiction without discrimination of any kind, irrespective of the child's or his or her parent's or legal guardian's race, colour, sex, language, religion, political or other opinion, national, ethnic or social origin, property, disability, birth or other status. ${ }^{236}$

By its express terms, the CRC is not limited to the nationals of the state nor its territory. Instead, it covers any child within the state's "jurisdiction."

The next question is what we mean by "jurisdiction." The use of this expression for the scope of human rights is fairly common among human rights treaties. In the context of human rights treaties, this term is used slightly differently than in general international law. Human rights treaties limit their application to the "jurisdiction" of the party, as opposed to the nationality of the victim. ${ }^{237}$ For example, the European Convention on Human Rights (ECHR) provides: "The High Contracting Parties shall secure to everyone within their jurisdiction the rights and freedoms defined in Section I of this Convention." ${ }^{238}$ In the case of the ICCPR, states parties are

236. See Convention on the Rights of the Child, supra note 1, art. 2.

237. See Estrella v. Uruguay, U.N. Human Rights Comm., Commc’n No. 74/1980, 9 4.1, U.N. Doc. CCPR/C/OP/2 (Mar. 29, 1983) [hereinafter Commc'n No. 74/1980]; see also International Convention on the Protection of the Rights of All Migrant Workers and Members of Their Families, art. 7, Dec. 18, 1990, 2220 U.N.T.S. 3 [hereinafter Migrant Workers Convention]. Cf. Convention on the Elimination of Racial Discrimination, supra note 194, art. 3 ("[U]ndertak[ing] to prevent, prohibit and eradicate [racial segregation and apartheid and] all practices of this nature in territories under their jurisdiction.").

238. Convention for the Protection of Human Rights and Fundamental Freedoms, art. 1, Nov. 4, 1950, 213 U.N.T.S. 221; see also American Convention on Human Rights, art. 1(1), Nov. 22, 1969, 1144 U.N.T.S. 123 . 
obliged to "respect and to ensure [the rights in the ICCPR] to all individuals within its territory and subject to its jurisdiction."239 The Convention Against Torture (CAT) also prohibits acts of torture within territory under the state's jurisdiction, ${ }^{240}$ although it prohibits non-refoulement to "another State." 241

In drafting these provisions, the states deliberately used the two terms "jurisdiction" and "territory," suggesting that they have distinct meanings. While some early drafts of human rights instruments attempted to limit the application to individuals residing within the state's territory, this approach was seen as too restrictive, as it might provide grounds to discriminate between residents and nonresidents. For this reason, the drafters switched to language of "jurisdiction" rather than "territory." 242 While the drafters may have been attempting to solve the problem of residency, that context should not necessarily limit the word "jurisdiction." 243 Furthermore, some human rights treaties use both expressions "territory" and "jurisdiction," sometimes in combination, and sometimes apart, clearly evidencing that states realized that the terms had distinct meanings. ${ }^{244}$ This conclusion that the terms are distinct has been upheld by the Human Rights Committee. ${ }^{245}$

In some cases, the two terms are clearly meant to interact. Some treaties might apply to jurisdiction "or" territory, leaving us to conclude that the

239. ICCPR, supra note 235, art. 2(1); see also Gueye v. France, U.N. Human Rights Comm., Commc'n No. 196/1985, U.N. Doc. CCPR/C/35/D/196/1985 (Oct. 12, 1985) [hereinafter Commc'n No. 196/185].

240. See UNCAT, supra note 55, art. 2(1); see also U.N., Comm. Against Torture, Consideration of Reports Submitted by State Parties Under Article 19 of the Convention, q1 15, 20, U.N. Doc. CAT/C/USA/CO/2 (July 25, 2006); J.H.A. v. Spain, U.N. Comm. Against Torture, Commc'n No. 323/2007, I 8.2, U.N. Doc. CAT/C/41/D/323/2007 (Nov. 21, 2008) [hereinafter Commc'n No. 323/2007].

241. See UNCAT, supra note 55, art. 3(1).

242. In the context of the ECHR, see 3 COUNCIL OF EUR., COLLECTED EDITION OF THE 'TRAVAUX PRÉPARATOIRES’ OF THE EUROPEAN CONVENTION ON HUMAN RIGHTS 260 (1976); Banković v. Belgium, 2001-XII Eur. Ct. H.R. 333, paras. 19-21.

243. In this regard one must also keep in mind that, under the VCLT rules on interpretation, a term is interpreted in line with the general rule of interpretation unless it is established that the parties intended a special meaning to apply. Vienna Convention on the Law of Treaties, supra note 53, art. 31.

244. See ICCPR, supra note 235, art. 2(1); Second Optional Protocol to the International Covenant on Civil and Political Rights, Aiming at the Abolition of the Death Penalty, art. 1, Dec. 15, 1989, 1642 U.N.T.S. 414; Convention on the Elimination of Racial Discrimination, supra note 194, art. 3; UNCAT, supra note 55, art. 2(1); Inter-American Convention on Forced Disappearance of Persons, arts. 1, 4, 6, opened for signature June 9, 1994, 33 I.L.M. 1529 (entered into force Mar. 28, 1996); International Convention for the Protection of All Persons from Enforced Disappearance, arts. 9, 11, 31, 34, Dec. 20, 2006, 2716 U.N.T.S. 3.

245. See U.N., Human Rights Comm., General Comment No. 31: The Nature of the General Legal Obligation Imposed on States Parties to the Covenant, ๆ 10, U.N. Doc. CCPR/C/21/Rev.1/Add.13 (May 26, 2004) [hereinafter HRC, Obligation to Covenant]. 
treaty must necessarily apply outside of the territory of the state. ${ }^{246}$ Other treaties might require jurisdiction "and" territory, ${ }^{247}$ which might lead us to believe that they are limited to only that territory where the state exercises jurisdiction. But this is not the usual interpretation. Generally, the conjunctive is read as disjunctive. ${ }^{248}$ The Human Rights Committee indeed interprets the provision to cover either territory or jurisdiction. ${ }^{249}$ The CRC, however, only uses the term jurisdiction.

The Holy See could have limited the application of the CRC to an even narrower situation than where it has jurisdiction. Not only could it have argued for a more limited scope, but it could have also entered a reservation. However, there are no specific terms in the Convention's text that pertain uniquely to the Holy See.

Turing to the reservations, the Holy See also did not enter any communication limiting the scope of application of the CRC to its activities administering territory. ${ }^{250}$ As mentioned above, the Holy See entered three reservations and one declaration. Two of the reservations pertain to the applicability of the CRC to certain issues, specifically, family planning education and the rights of parents to guide their children's education and religious upbringing, which are not relevant to jurisdiction. The third reservation stated that the "application of the Convention [must] be compatible in practice with the particular nature of the Vatican City State and of the sources of its objective law . . . and . . legislation in the matters of citizenship, access and residence." 251 The Holy See also included text in its declaration, referenced above, that its accession "does not intend to prescind in any way from its specific mission which is of a religious and moral character." ${ }^{252}$ No state objected to any of these communications.

246. See Migrant Workers Convention, supra note 237.

247. See ICCPR, supra note 235, art. 2(1); Convention on the Elimination of Racial Discrimination, supra note 194, art. 3; UNCAT, supra note 55, art. 2(1).

248. See HRC, Obligation to Covenant, supra note 245, ๆ 10.

249. See id.; U.N., Human Rights Comm., Consideration of Reports Submitted by States Parties Under Article 40 of the Covenant, ๆ 19, U.N. Doc. CCPR/C/79/Add.50 (Apr. 7, 1995) [hereinafter HRC, Consideration of Reports 1995]; Kindler v. Canada, U.N. Human Rights Comm., Commc'n No. 470/1991, | 6.2, U.N. Doc. CCPR/C/48/D/470/1991 (Sept. 25, 1991) [hereinafter Commc'n No. 470/1991]; A.R.J. v. Australia., U.N. Human Rights Comm., Commc'n No. 692/1996, ๆ 6.8, U.N. Doc. CCPR/C/60/D/692/1996 (July 28, 1997); Saldia de Lopez v. Uruguay, U.N. Human Rights Comm., Commc'n No. 52/1979, ๆๆ 12.1-.3, U.N. Doc. CCPR/C/OP/1 (July 29,1981) [hereinafter Commc'n No. 52/1979].

250. See Convention on the Rights of the Child, supra note 1, at 175-77; Status of the CRC, supra note 3 .

251. Convention on the Rights of the Child, supra note 1, at 176; Status of the CRC, supra note 3.

252. Convention on the Rights of the Child, supra note 1, at 177; Status of the CRC, supra note 3; see also List of Issues in Relation to the Second Periodic Report, supra note 9, ๆๆ 6-7. 
The declaration does not provide a significant limitation to the treaty's scope of application. The use of the term "prescind" is unusual. A quick search through the UN Treaty Collection reveals only one mention of that term aside from the CRC, which was the Holy See's declaration concerning the United Nations Convention against Illicit Traffic in Narcotic Drugs and Psychotropic Substances. ${ }^{253}$ After drawing the attention of the parties to the issues of drug trafficking, the Holy See stated that "[i]n adhering to this Convention, the Holy See does not intend to prescind in any way from its specific mission which is of a religious and moral character." ${ }^{254}$ Aside from this instance, the term is not commonly used and the Narcotic Drugs Trafficking Convention does not help in defining the term, so it is difficult to identify any meaning of the term that would be particular to international law. In regular usage, "prescind" is commonly defined as withdrawing, detaching or separating an issue. ${ }^{255}$ Thus, the reservation could mean that the Holy See's participation in the treaty is not intended to undermine the moral role of the Holy See in the international community. However, this reservation says nothing about exempting the application of the CRC to either the territory of the Vatican City or the Holy See generally. Although a declaration lacks any legal effect, ${ }^{256}$ even if it did, the declaration does not argue that the Holy See seeks to alter its legal obligations. It could have, for example, included a reservation that exempted certain substantive obligations, preserving solely its moral leadership. It did not. ${ }^{257}$ Interestingly, in none of its compliance reports does the Holy See argue that substantive provisions of the CRC do not apply to it. Instead, it submits evidence of compliance with the substantive terms of the CRC. ${ }^{258}$

The third reservation seeks to alter the legal effect of the CRC by limiting its application in relation to the Vatican City. Specifically, the reservation draws our attention to the "limited extent" 259 of the state and specifically mentions that "matters of citizenship, access and residence" 260

253. See United Nations Convention Against Illicit Traffic in Narcotic Drugs and Psychotropic Substances, Dec. 20, 1988, 1582 U.N.T.S. 95.

254. Status of the United Nations Convention Against Illicit Traffic in Narcotic Drugs and Psychotropic Substances, UNITED NATIONS TREATY COLLECTION, https://treaties.un.org/Pages/ ViewDetails.aspx?src=TREATY\&mtdsg_no=VI-19\&chapter $=6 \&$ clang $=$ en $\quad[\mathrm{https}: / /$ perma.cc/K5EBDP56] (last visited Feb. 27, 2021).

255. Prescind, MERRIAM-WEBSTER, https://www.merriam-webster.com/dictionary/prescind [https: //perma.cc/8LZ8-VYY8] (last visited Jan 21, 2021).

256. See Belilos v. Switzerland, 132 Eur. Ct. H.R. (ser. A) at 24-28, paras. 49, 60 (1988).

257. See Convention on the Rights of the Child, supra note 1, at 175-77; Status of the CRC, supra note 3 .

258. See Initial Reports of States Parties Due in 1992, supra note 16.

259. Convention on the Rights of the Child, supra note 1, at 176; Status of the CRC, supra note 3.

260. Convention on the Rights of the Child, supra note 1, at 176; Status of the CRC, supra note 3. 
will not be affected by the CRC's obligations. The CRC does contain terms on the rights of children in these matters, and given the small size of the Vatican, the reservation is understandable. The reservation also notes that generally the application of the CRC must be compatible with the "particular nature of the Vatican City State and of the sources of its objective law."261 What is important about this reservation is that, while it limits the scope of application of the CRC, it acknowledges that the CRC applies to the Vatican City. However, as discussed above, the Vatican is not a party, so the terms on application to the Vatican can only implicate the Holy See's measures to govern the Vatican. In its submissions to the Committee, the Holy See affirmed this point: that the CRC applies to its governance of the Vatican City. ${ }^{262}$ More importantly, the reservation does not exclude or limit the application of the CRC to the Holy See. Thus, the reservation clarifies that the Holy See is a party to the CRC, that the CRC applies to all of its worldwide activities, but that, in applying to the Holy See's territorial administration of the Vatican City, the application of the CRC does not impact Vatican law on citizenship or residence. In fact, the Holy See has recognized that the $\mathrm{CRC}$ does apply to its activities beyond the governance of the Vatican. ${ }^{263}$ In sum, we do not find that any of the reservations or declarations disturb the normal application of the CRC to the Holy See.

Because the CRC applies to the Holy See where it has jurisdiction, the next question seeks to understand the meaning of jurisdiction in relation to this unusual entity, not being a state and without territory. One view could be that the notion of jurisdiction cannot be applied to the Holy See as a sui generis entity. Although the Holy See initially submitted communications on its "implementation" of the CRC, it later attempted to evidence only "encouragement" of the CRC. ${ }^{264}$ This change in language suggests that the Holy See shifted from compliance with the CRC to mere moral support for the goals of the CRC, though this change was never made explicitly. The Holy See has asserted that its participation in treaties is a way to "manifest the support of its moral authority" to the treaty. ${ }^{265}$ It argues that its teachings

261. Convention on the Rights of the Child, supra note 1, at 176; Status of the CRC, supra note 3.

262. See Comments of the Holy See, supra note 28, para. 3.

263. See id.

264. See List of Issues in Relation to the Second Periodic Report, supra note 9, $₫ 20$.

265. See CERD, Consideration of Reports 2000, supra note 23, - 4(h) ("The Holy See signs and ratifies international treaties in order to manifest the support of its moral authority and thereby to encourage States to adhere to the treaty. For example, in acceding to the Treaty on the Non-Proliferation of Nuclear Weapons in 1979, it clearly stated that 'by this act, dictated by the conviction that the objectives of disarmament and international détente ... which inspire this treaty correspond to its own mission of peace, the Holy See wishes to give its support and its moral encouragement to the provisions of the treaty."'). 
and moral role are not only for the benefit of Catholic believers, but also for everyone. ${ }^{266}$ However, an entity need not adhere to a treaty to promote it or assert any moral authority. The Holy See, and any state for that matter, could take that approach without becoming a party. Binding oneself to international obligations, though, goes beyond encouragement and has legal consequences. The fact that the Holy See entered reservations and a declaration shows that it clearly understood that it was bound to legal obligations by adhering to the CRC, or else it would not have attempted to limit the legal application of the treaty.

If the Holy See was sui generis to this extreme that it did not bear obligations under treaty law, it is difficult to understand how it would participate in international law. "Sovereignty" in any sense would be a word without content. We should take note that the Holy See has, in fact, consistently insisted that it participate in international law, and that norms of international law bind it, just as they bind other subjects of international law. For example, the Holy See has submitted its organs and activities to international supervision in the past. ${ }^{267}$ In fact, according to the Holy See, international law occupies a higher position than its own "domestic" laws. ${ }^{268}$

Not only does it participate on par with states, but it must be capable of exercising jurisdiction within the meaning of the CRC. The Holy See has adhered to a treaty whose application is clearly based on having jurisdiction and has accepted that it will have legal obligations. Without terms or practice to suggest otherwise, the participation of the Holy See cannot be meaningless. The Holy See must have considered that it would be bound to activities within its jurisdiction when it adhered to the CRC, and in fact, its declarations and reservations attempting to limit the legal scope of its obligations suggest that it was clearly aware that its participation would have legal, not only moral, consequences. The Holy See has affirmed that it is aware of the notion of jurisdiction applies to it. ${ }^{269}$ Scholars have concluded

266. See id. If 4(i) ("The Holy See, as the supreme organ of the Catholic Church, disseminates teachings which are not addressed to Catholic believers alone but also concern human, personal, social and international ethics. In the tradition of the Catholic Church, ethical principles are founded upon reason and address themselves to the whole of mankind."); CERD, Consideration of Reports 2014, supra note 17, ๆ 10.

267. See Question by Saïd El Khadraoui, supra note 140 ("The Holy See submitted the IOR [Institute for Religious Works, i.e. Vatican Bank] to the supervision of the Council of Europe's money-laundering watchdog, the Committee of Experts on the Evaluation of Anti-Money Laundering Measures and the Financing of Terrorism (Moneyval).").

268. See CERD, Consideration of Reports 2000, supra note 23, $\uparrow 10$ (b).

269. See Agreement for the Application of Safeguards, supra note 48, art. 1 ("The Holy See undertakes ... to accept safeguards ... on all source or special fissionable material in all peaceful nuclear activities within the territory of the Vatican City State, under the jurisdiction of that State or carried out under its control anywhere, for the exclusive purpose of verifying that such material is not diverted to 
that the Holy See, not the Vatican City, enjoys jurisdiction in the same manner as states. ${ }^{270}$ The Holy See further asserts that it enjoys jurisdiction under its own interpretation of that term and has used that term in treaties previously, ${ }^{271}$ including the Convention on the Elimination of All Forms of Racial Discrimination (CERD) ${ }^{272}$ and CAT. ${ }^{273}$

Although jurisprudence of the CommRC applying the $\mathrm{CRC}$ is not as developed as that of the ECHR and other treaties, indications are that the $\mathrm{CRC}$ is and will be interpreted in line with the general trend in human rights treaties on jurisdiction. For example, the Committee on the Rights of the Child has concluded that a state must ensure the human rights of children in its entire territory, including regions with degrees of autonomy. ${ }^{274}$ The Committee has also stated that the Convention applies to "each child within

nuclear weapons or other nuclear explosive devices.”); Id. Protocol, para. I(1) ("Until such time as the Holy See has, in peaceful nuclear activities within the territory of the Vatican City State or under the jurisdiction or control of that State anywhere ....").

270. See Finn Seyersted, Jurisdiction over Organs and Officials of States, the Holy See and Intergovernmental Organisations (1), 14 INT'L \& COMP. L.Q. 31, 43, 46 (Jan. 1965) (stating that the Holy See has jurisdiction over its organs comparable to a State-i.e., its diplomats have the same prerogatives and immunities as States; and many States, Catholic and some non-Catholic, have an international obligation to allow the jurisdiction of the Catholic Church in the concordat framework).

271. See, e.g., Holy See Signs Accord with Czech Republic (July 29, 2002, 2:50 PM), https://wikileaks.org/plusd/cables/02VATICAN3717_a.html [https://perma.cc/P5T9-JRNS] (“(SBU) THE HOLY SEE SIGNED A JURIDICAL ACCORD WITH THE CZECH REPUBLIC JULY 25 REGULATING THE STATUS OF THE CATHOLIC CHURCH. THE AGREEMENT, REACHED AFTER THREE YEARS OF OCCASIONALLY DIFFICULT NEGOTIATIONS, GUARANTEES THE CATHOLIC CHURCH FREEDOM TO CONDUCT ITS ACTIVITIES, IN PARTICULAR WORSHIP, GOVERNMENT OF ITS JURISDICTIONS, AND EDUCATION."); see also U.S. and Holy See Agreement to Improve Tax Compliance, supra note 134, art. 1(1)(m) ("The term 'Partner Jurisdiction Financial Institution' means (i) any Financial Institution established in a Partner Jurisdiction, but excluding any branch of such Financial Institution that is located outside the Partner Jurisdiction, and (ii) any branch of a Financial Institution not established in the Partner Jurisdiction, if such branch is located in the Partner Jurisdiction.”). Note that excluded entities would be those incorporated or established within the jurisdiction but located outside the jurisdiction. If the agreement only applied to the Vatican City, then the term "territory" would have been used or would have otherwise referred to the Vatican as it was in other parts of the same treaty. See id. art. 1(1)(1) ("located outside the Vatican City State . ..."). The use of "jurisdiction" in article 1(1)(m) must be understood to apply to the jurisdiction of the Holy See.

272. See Convention on the Elimination of Racial Discrimination, supra note 194, art. 6.

273. See UNCAT, supra note 55, art. 2(1).

274. See U.N., Comm. on the Rights of the Child, General Measures of Implementation of the Convention on the Rights of the Child, 9 甲 1, 40-41, U.N. Doc. CRC/GC/2003/5 (Nov. 27, 2003); U.N., Comm. on the Rights of the Child, Ninth Session Summary Record of the 214th Meeting, 945 , U.N. Doc. CRC/C/SR.214 (May 30, 1995); U.N., Comm. on the Rights of the Child, Consideration of Reports Submitted by States Parties Under Article 44 of the Convention, Concluding Observations: Canada, 9 , U.N. Doc. CRC/C/15/Add.215 (Oct. 27, 2003); U.N., Comm. on the Rights of the Child, Consideration of Reports Submitted by States Parties Under Article 44 of the Convention, Concluding Observations of the Committee on the Rights of the Child: United Kingdom of Great Britain and Northern Ireland-Isle of Man, $\uparrow \uparrow$ 4, 5, U.N. Doc. CRC/C/15/Add.134 (Oct. 16, 2000). 
the State's territory and to all children subject to its jurisdiction" 275 rather than limiting the treaty to the state nationals. ${ }^{276}$ Also, the Committee has concluded that the term "jurisdiction" does not refer to the enforcement jurisdiction of courts or prescriptive jurisdiction of a legislature or any other meaning. Instead, it refers to the jurisdiction of the state generally. ${ }^{277}$ This view is in line with the interpretation of "jurisdiction" in other human rights treaties. While jurisdiction is primarily viewed as a territorial issue, ${ }^{278}$ it is not solely a question of law, but also one of fact. ${ }^{279}$ For example, the state exercises jurisdiction even when the child is at the border, ${ }^{280}$ and even where the state has, by law, excluded its jurisdiction. ${ }^{281}$ In line with the interpretation of other human rights instruments and the indications from the Committee, we must interpret "jurisdiction" in the CRC as something different from "territory." Thus, any situation where a state exercises jurisdiction, whether it be within its territory or outside its territory, the CRC will govern.

\section{A. Territorial Jurisdiction in Human Rights Law}

Following from the discussion above, the first possibility for the Holy See to incur human rights obligations under the $\mathrm{CRC}$ would be for it to exercise territorial jurisdiction. However, the Holy See lacks territory. When a human rights treaty applies to a state's jurisdiction (or "territory and jurisdiction"), the usual interpretation is that it covers the state's lawful territory. The general approach is that "jurisdiction" is meant to be understood in terms of public international law and is primarily territorial. ${ }^{282}$ Following from this conclusion, the European Court of Human Rights and other human rights monitoring bodies have held that the application of

275. See U.N., Comm. on the Rights of the Child, Treatment of Unaccompanied and Separated Children Outside Their Country of Origin, 9 | 12, 76-77, U.N. Doc. CRC/GC/2005/61 (Sept. 2005).

276. See id. 112.

277. See id. $₫ 13$.

278. See id. $\llbracket 12,33$.

279. See id. $\ 78$.

280. See id. $\uparrow 12$.

281. See id.

282. See Longa v. Netherlands, 2012-IV Eur. Ct. H.R. 449, para. 69; Sargsyan v. Azerbaijan, 2015IV Eur. Ct. H.R. 1, para. 128; Ilaşcu v. Moldova, 2004-VII Eur. Ct. H.R. 179, para. 312; Gentilhomme v. France, App. Nos. 48205/99, 48207/99, \& 48209/99, para. 20 (Eur. Ct. H.R., 2002), http://hudoc.echr.coe.int/eng?i=001-65008 [https://perma.cc/R58H-LXJ2]; Banković v. Belgium, 2001XII Eur. Ct. H.R. 333, paras. 59-61; Assanidze v. Georgia, 2004-II Eur. Ct. H.R. 221, para. 137; Gonzalez v. Guyana, U.N. Human Rights Comm., Commc'n No. 1246/2004, 『 13.3, U.N. Doc. CCPR/C/98/D/1246/2004 (May 21, 2010) [hereinafter Commc'n No. 1246/2004]; Jamaa v. Italy, 2012II Eur. Ct. H.R. 97, para. 75. 
human rights conventions is primarily over territory. ${ }^{283}$ For example, the Committee Against Torture has held that complainants in a case are subject to the jurisdiction of the state, ${ }^{284}$ and that lawful expulsion of a person to a situation where human rights are violated may be a violation within the expelling state's jurisdiction. ${ }^{285}$ On this basis, a state will not usually have jurisdiction within the territory of another state. ${ }^{286}$

Of course, there will be exceptions where a state does not exercise jurisdiction within its own territory, but these are few. ${ }^{287}$ The first exception

283. See Banković, 2001-XII Eur. Ct. H.R. paras. 59-61; Commc'n No. 1246/2004, supra note 282.

284. See Guengueng v. Senegal, U.N. Comm. Against Torture, Commc'n No. 181/2001, ๆๆ 6.3-.4, U.N. Doc. CAT/C/36/D/181/2001 (May 19, 2006).

285. See Ng v. Canada, U.N. Human Rights Comm., Commc'n No. 469/1991, ฯ 6.2, U.N. Doc. CCPR/C/49/D/469/1991 (Jan. 7, 1994); Commc'n No. 470/1991, supra note 249, \ 6.2; HRC, Obligation to Covenant, supra note $245, \boldsymbol{\top} 12$.

286. See H.W.A. v. Switzerland, U.N. Comm. Against Torture, Commc'n No. 48/1996, qq 4.2-.3, U.N. Doc. CAT/C/20/D/48/1996 (June 19, 1998) [hereinafter Commc'n No. 48/1996]; Jamaa, 2012-II Eur. Ct. H.R. para. 72; Drozd v. France, Appl. No. 12747/87, para. 91 (Eur. Ct. H.R., 1992), http://hudoc.echr.coe.int/eng?i=001-57774 [https://perma.cc/79FU-QAJ2\#\{\%22itemid\%22:[\%2200157774\%22]\}]; Banković, 2001-XII Eur. Ct. H.R. para. 67; Ilaşcu, 2004-VII Eur. Ct. H.R. para. 314; Loizidou v. Turkey, 310 Eur. Ct. H.R. (ser. A) at 23-24, para. 62 (1995); Al-Skeini v. United Kingdom, 2011-IV Eur. Ct. H.R. 99, paras. 132, 136. Also, aliens who present themselves at a state's borders and are not yet admitted are also deemed to fall within the state's jurisdiction. See G.A. Res. 2312 (XXII), art. 3, Declaration on Territorial Asylum (Dec. 14, 1967); OAU Convention Governing the Specific Aspects of Refugee Problems in Africa, art. II(3), Sept. 10, 1969, 1001 U.N.T.S. 45; U.N. High Comm'r for Refugees, Cartagena Declaration on Refugees, § III(5) (Nov. 22, 1984), https://www.unhcr.org/aboutus/background/45dc19084/cartagena-declaration-refugees-adopted-colloquium-international-protection .html [https://perma.cc/RTE9-5TPC]; Convention Relating to the International Status of Refugees, art. 3, Oct. 28, 1933, 159 L.N.T.S. 199; Sale v. Haitian Ctrs. Council, 509 U.S. 155 (1993); R v. Immigration Officer at Prague Airport [2004] UKHL 55, [2005] 2 AC (HL) 37-38 (appeal taken from Eng.); U.N. High Comm'r for Refugees, Guidelines for National Refugee Legislation, with Commentary, § 6(2), U.N. Doc. HCR/120/41/80/GE.81-0013 (Dec. 9, 1980); UNHCR EXEC. COMM., Conclusion on NonRefoulment, No. 6 (XXVIII) (Oct. 12, 1977), https://www.unhcr.org/en-us/excom/exconc/3ae68c43ac/ non-refoulement.html [https://perma.cc/FB3C-JV7S]; UNHCR EXEC. COMM., Conclusion on Refugees Without an Asylum Country, No. 15 (XXX) (Oct. 16, 1979), https://www.unhcr.org/en-us/excom/ exconc/3ae68c960/refugees-asylum-country.html [https://perma.cc/F2JF-REQB]; UNHCR EXEC. COMM., Conclusion on Stowaway Asylum-Seekers, No. 53 (XXXIX) (Oct. 10, 1988), https://www.unhcr .org/en-us/excom/exconc/3ae68c4374/stowaway-asylum-seekers.html [https://perma.cc/8R8U-WGRP]; Jamaa, 2012-II Eur. Ct. H.R. at 183 (Pinto de Albuquerque, J., concurring).

287. See Ilaşcu, 2004-VII Eur. Ct. H.R. at 317-19 (Baratza, N., dissenting, joined by Rozakis, Hedigan, Thomassen and Pantiru); H.v.d.P v. Netherlands, U.N. Human Rights Comm., Commc'n No. 217/1986, U.N. Doc. CCPR/C/29/D/217/1986 (Apr. 8, 1987) [hereinafter Commc'n No. 217/1986] (decision on admissibility); Rep. of the Human Rights Comm. on its Forty-Second Session, at 185, U.N. Doc. Supp. No. 40 A/42/40 (1987) [hereinafter HRC, 1987 Report]; U.N. HIGH COMM'R FOR HUMAN

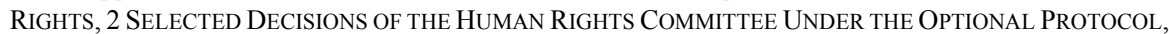
at 71, U.N. Doc. CCPR/C/OP/2, U.N. Sales No. E.89.XIV.1 (1990); E.M.E.H. v. France, U.N. Human Rights Comm., Commc'n No. 409/1990, U.N. Doc. CCPR/C/40/D/409/1990 (Nov. 2, 1990) (decision); Rep. of the Human Rights Comm. on Its Forty-Sixth Session, at 318-19, U.N. Doc. Supp. No. 40 A/46/40 (Oct. 10, 1991); U.N. High COMM'R FOR Human Rights, 4 SElECTED DeCisions of the HuMAN Rights Committee Under the Optional Protocol, at 29, U.N. Doc. CCPR/C/OP/4, U.N. Sales No. 
is when the state is an occupying power or otherwise exercising effective control over the territory. In order to trigger the belligerent occupation option, the ECHR has concluded that there must be troops physically controlling the territory, ${ }^{288}$ and that they should "exercise ... some of the public powers normally to be exercised by a sovereign government . . ..."289 The second exception is when a state no longer exercises jurisdiction over the activities of an international organization located within the state. ${ }^{290}$ In these situations a state must still take whatever legal, political and other steps it can to prevent violations by other actors within the state's jurisdiction. ${ }^{291}$

Therefore, the first possibility for whether activities fall within the Holy See's jurisdiction for purposes of the CRC is situations in which the Holy See has territorial jurisdiction. The Holy See has argued that the application of the CRC is territorial, at least prima facie. ${ }^{292}$ Following that, the Holy See has accepted that its activities in the Vatican City are covered. ${ }^{293}$

The problem is that this conclusion is impossible. The Holy See is, by definition, a non-territorial entity, so it cannot have any territory. Instead, the Holy See governs a state that itself has territory. As noted above, the Holy See repeatedly affirms this. Curiously, the Holy See also affirms it has "jurisdiction" over activities within the Vatican City. ${ }^{294}$ If it has jurisdiction, then it can only be extraterritorial jurisdiction. Because the Holy See, not the Vatican City, is party to the CRC, and the Holy See expressly affirms its jurisdiction over Vatican City, then it must be implicitly affirming that the CRC also applies to extraterritorial jurisdiction.

04.XIV.7 (2004); Koi v. Portugal, U.N Human Rights. Comm., Commc’n No. 925/2000, \6.7, U.N. Doc. CCPR/C/73/D/925/2000 (Oct. 22, 2001); Munaf v. Romania, U.N. Human Rights Comm., Commc'n No. 1539/2006, ๆ 14.2, U.N. Doc. CCPR/C/96/DR/1539/2006 (Aug. 21, 2009). Also note that a state is presumed to be in control of its lawful territory, see Sargsyan, 2015-IV Eur. Ct. H.R. para. 140; Ilaşcu, 2004-VII Eur. Ct. H.R., paras. 311-12; Assanidze, 2004-II Eur. Ct. H.R. para. 139.

288. Sargsyan, 2015-IV Eur. Ct. H.R. para. 144.

289. Al-Skeini, 2011-IV Eur. Ct. H.R. paras. 135-39; see also Loizidou, 310 Eur. Ct. H.R. (ser. A).

290. See Longa v. Netherlands, 2012-IV Eur. Ct. H.R. 449, paras. 73-75, 81-84 (decision on admissibility); Commc'n No. 217/1986, supra note 287 (decision on admissibility); HRC, 1987 Report, supra note 287, at 185. But see William Thomas Worster, Contracting Out of Non-Refoulement Protections, 27 TRANSNAT'L L. \& CONTEMP. PROBS. 77, 87-97 (2017) (criticizing this exception and the line of cases supporting it on several grounds).

291. See Ilaşcu, 2004-VII Eur. Ct. H.R. para. 313.

292. See Comments of the Holy See, supra note 28, para. 10(b) ("This interpretation is contrary to obligations under the $\mathrm{CRC}$, which are prima facie territorial, taking into consideration the Vienna Convention on the Law of Treaties, and a facial reading of the treaty together with the general understanding of jurisdiction as previously discussed in the Holy See's Written Replies.") (emphasis in original).

293. See id. para. 3 .

294. See Lateran Accords, supra note 9, art. 9; Initial Reports of States Parties Due in 1992, supra note 16, $\mathbb{\|}$; List of Issues in Relation to the Second Periodic Report, supra note 9, $\uparrow \uparrow 10$ (b), 17. 


\section{B. Extraterritorial Jurisdiction in Human Rights Law}

In addition to territorial jurisdiction, jurisdiction in human rights treaties can go beyond the state's territory. ${ }^{295}$ Another possibility then for the Holy See to exercise jurisdiction would be for it to have extraterritorial jurisdiction. As a non-territorial entity, all of its acts must be extraterritorial, and thus this alternative would be a stronger possibility for finding jurisdiction. Extraterritorial jurisdiction could be established by acts taken within the states that have extraterritorial effect, or acts taken outside the state where the state has either effective control over territory or persons. ${ }^{296}$

\section{Jurisdiction When a State Affects Human Rights Abroad}

The first category of acts with extraterritorial effect encompasses those that occur within the state, and impact the enjoyment of rights within the state, but the person is outside of the state. ${ }^{297}$ For example, a state might unlawfully confiscate a person's home or belongings while the owner is abroad. This scenario is not truly extraterritorial because the acts and effect are within the state, but the presence of the person outside the state means it has extraterritorial effect. In this situation, the European Court of Human Rights has easily found such conduct to occur where a state has jurisdiction, and consequently, for the ECHR to apply. ${ }^{298}$ Similarly, the Human Rights Committee has concluded that the ICCPR also applies in this scenario. ${ }^{299}$ Certainly, when the courts of a state exercise jurisdiction over an individual's rights within that state, then the state is exercising jurisdiction. ${ }^{300}$

295. See HRC, Consideration of Reports 1995, supra note 249, I 19; Armed Activities on the Territory of the Congo (Dem. Rep. Congo v. Uganda), Judgment, 2005 I.C.J. 168, \ 179 (Dec. 19); Velásquez Rodríguez v. Honduras, Merits, Judgment, Inter-Am. Ct. H.R. (ser. C) No. 4, 172 (July 29, 1988); HRC, Obligation to Covenant, supra note 245; Soering v. United Kingdom, 161 Eur. Ct. H.R. (ser. A) at 33-34, para. 86 (1989); Banković v. Belgium, 2001-XII Eur. Ct. H.R. 333, paras. 66-67; Massiotti v. Uruguay, U.N. Human Rights Comm., Commc'n No. 25/1978, U.N. Doc. CCPR/C/16/D/25/1978 (July 26, 1982); Acosta v. Uruguay, U.N. Human Rights Comm., Commc'n No. 110/1981, 『 6, U.N. Doc. CCPR/C/21/D/110/1981 (Mar. 29, 1984); Miha v. Equatorial Guinea, U.N. Human Rights Comm., Commc'n No. 414/1990, ๆ 5.1, U.N. Doc. CCPR/C/51/D/414/1990 (Aug. 10, 1994).

296. See HRC, Consideration of Reports 1995, supra note 249, \ 19.

297. See Montero v. Uruguay, U.N. Human Rights Comm., Commc'n No. 106/1981, U.N. Doc. CCPR/C/18/D/106/1981 (Mar. 31, 1983) [hereinafter Commc'n No. 106/1981].

298. See, e.g., Liberty v. United Kingdom, 48 Eur. H.R. Rep. 1 (2009); Weber v. Germany, 2006XI Eur. Ct. H.R. 309; Bosphorus Hava Yollari Turizm ve Ticaret Anonim Sirketi v. Ireland, 2005-VI Eur. Ct. H.R. 107.

299. See Commc'n No. 196/185, supra note 239; Martins v. Uruguay, U.N. Human Rights Comm., Commc'n No. 57/1979, U.N. Doc. CCPR/C/15/D/57/1979 (Mar. 23, 1982) [hereinafter Commc'n No. 57/1979].

300. See Markovic v. Italy, 2006-XIV Eur. Ct. H.R. 235, paras. 54-55. 
The next question is whether the Holy See could ever act in a similar manner, which would have an impact domestically on the rights of a person who is abroad. It could be that this type of jurisdiction requires territory and actions within the territory, such as property rights. However, since the Holy See has no territory, then this form of jurisdiction would never occur, and this form of extraterritorial jurisdiction would be meaningless in relation to the Holy See. However, the actions only need to occur within the entity while the individual is abroad, and, as a non-territorial entity, all individuals are outside of the territory of the entity. Acts occurring within the entity could mean actions affecting rights within the Holy See, i.e. within the governing authority of the Church. One way in which the Holy See exercises jurisdiction is with respect to marriage rights. The Holy See prescribes rules and regulations pertaining to marriage and annulment, ${ }^{301}$ which it defines as "jurisdiction." 302 Another example is the Holy See's internal justice system, asserting jurisdiction over civil and criminal violations, ${ }^{303}$ rendering judgments and imposing (non-custodial) sentences. ${ }^{304}$ All of these acts would be taken by the Holy See which have extraterritorial impact.

\section{Jurisdiction When Acts Create Effects Abroad}

A related category of extraterritorial jurisdiction is the situation where an entity acts and commits a violation abroad. These effects can be one of two types. They can include unlawful acts undertaken within a state, and the individual commits the violation abroad, e.g. Iran's fatwa against Salman Rushdie residing abroad. ${ }^{305}$ The other scenario is an unlawful act within the state that leads to the inevitable violation of a person's rights abroad, e.g. the

301. See Agreement Between the Holy See and the Republic of Malta on the Recognition of Civil Effects to Canonical Marriages and to the Decisions of the Ecclesiastical Authorities and Tribunals About the Same Marriages, Holy See-Malta, Protocol of Application, Second Additional Protocol, Feb. 3, 1993, 89 Acta Apost. Sedis. 683 [hereinafter Agreement Between the Holy See and the Republic of Malta]; Concordat Between the Holy See and Spain, supra note 60, art. XXIV(1), (4); Agreement Concerning Legal Matters, Holy See-Spain, arts. II, VI, Jan. 3, 1979, 1154 U.N.T.S. 73 [hereinafter Agreement Concerning Legal Matters]; Apostolic Letter from Pope Francis, Mitis Iudex Dominus Iesus (Aug. 15, 2015), http://www.vatican.va/content/francesco/en/motu_proprio/documents/papa-francesco-motu-pro prio_20150815_mitis-iudex-dominus-iesus.html [https://perma.cc/NH9D-4WKJ]; Second Reports of States Parties Due in 1997, supra note 16, 1112.

302. See Concordat Between the Holy See and Spain, supra note 60, art. XXIV(4).

303. See id. arts. XVI(3), XXV(1).

304. See id. art. XVI(5).

305. See U.N., Human Rights Comm., Consideration of Reports Submitted by States Parties Under Article 40 of the Covenant: Comments on Iran, U.N. Doc. CCPR/C/79/Add.25 (Aug. 3, 1993) [hereinafter HRC Comments: Iran]; Commc'n No. 52/1979, supra note 249, 1 12.2; Casariego v. Uruguay, U.N. Human Rights Comm., Commc'n No. 56/1979, 1 甲 10.1-.2, U.N. Doc. CCPR/C/13/D/56/1979 (July 29, 1981) [hereinafter Commc'n No. 56/1979]; Loizidou v. Turkey, 310 Eur. Ct. H.R. (ser. A) at 23-24, paras. 62-63 (1995); Al-Skeini v. Sec'y of State for Def. [2007] UKHL 26, [2008] 1 AC (HL) 197 (appeal taken from Eng.). 
expulsion of a person to a situation where their human rights would likely be violated. $^{306}$ While the expulsion itself is lawful and does not constitute a violation, the mistreatment upon arrival in the receiving state is a foreseeable consequence, so the state is creating the conditions for the mistreatment to occur. Again, the acts are not extraterritorial, but the effects of the conduct are. On this basis, human rights tribunals have routinely found extraterritorial consequences of a state's conduct to fall within state's jurisdiction. $^{307}$

Compared to the scenario in section III(B)(1) where the act results in a violation within the state, the situations in this section are more clearly applicable to the Holy See. Without territory, all of the acts must be extraterritorial. As noted above, the Holy See maintains jurisdiction over marriage rights. ${ }^{308}$ Sometimes its rules on marriage can result civil effect within other states' legal systems. ${ }^{309}$ Another example would be in education, ${ }^{310}$ including obliging the state to provide religious education, ${ }^{311}$ or oversight of the contents of education. ${ }^{312}$ The Holy See also governs

306. See, e.g., Soering v. United Kingdom, 161 Eur. Ct. H.R. (ser. A) (1989).

307. See id. para. 111.

308. See Concordat between the Holy See and Spain, supra note 60, art. XXIV.

309. See Lateran Accords, supra note 9, art. 23; Concordat Between the Holy See and Spain, supra note 60, art. XXIII; Agreement Between the Italian Republic and the Holy See, supra note 34, art. 8.1; Agreement Concerning Legal Matters, supra note 301, art. VI; Agreement Between the Holy See and the Republic of Malta, supra note 301, Protocol of Application, Second Additional Protocol; Pellegrini v. Italy, 2001-VIII Eur. Ct. H.R. 369, para. 31 ("Under Article $8 \S 2$ of the Concordat . . a judgment of the ecclesiastical courts annulling a marriage, which has become enforceable by a decision of the superior ecclesiastical review body, may be made enforceable in Italy at the request of one of the parties by a judgment of the relevant court of appeal."). But see Solicitor Gen. of the Republic v. Polanco, 606 B.J. 49 (1961) (Dom. Rep.) (refusing to give automatic legal validity to marriages under canon law because the Constitution forbade delegations of state sovereignty). For the EU, see Council Regulation 2116/2004, art. 1, 2004 O.J. (L 367) 1; Council Regulation 2201/2003, art. 63, 2003 O.J. (L 338) 1; Proposal for a Council Regulation Amending Regulation (EC) No 2201/2003 Concerning Jurisdiction and the Recognition and Enforcement of Judgments in Matrimonial Matters and the Matters of Parental Responsibility, para. 2, COM (2004) 616 final (Sept. 29, 2004) (“As an exception to this rule, Article 40 stipulates that decisions taken by ecclesiastical courts in Spain, Italy and Portugal pursuant to the treaties between these Member States and the Holy See (referred to as 'Concordats') are recognised in other Member States pursuant to the rules of the Regulation. These treaties give the ecclesiastical courts in the Member States concerned competence to annul canonical marriages.").

310. See Second Reports of States Parties Due in 1997, supra note 16, 19 25-32; Concordat Between the Holy See and the Latvian Government, Holy See-Latvia, art. 10, May 30, 1922, 17 L.N.T.S. 365 [hereinafter Concordat with Latvia]; Fundamental Agreement Between the Holy See and the State of Israel, supra note 39, art. 6 ("The Holy See and the State of Israel jointly reaffirm the right of the Catholic Church to establish, maintain and direct schools and institutes of study at all levels; this right being exercised in harmony with the rights of the State in the field of education.").

311. See Concordat Between Holy See and Spain, supra note 60, art. XXVII.

312. See id. arts. XXVI, XXX-XXXI. 
medical services abroad. ${ }^{313}$ Lastly, the Holy See reserves the right under some concordats to resist assisting a state in criminal enforcement, such as the refusal to provide evidence. ${ }^{314}$ All of these acts constitute actions by the Holy See resulting in extraterritorial effects. ${ }^{315}$

\section{Jurisdiction When Acts are Undertaken Outside of the State}

The final situation of extraterritorial jurisdiction occurs when a state acts outside its territory. ${ }^{316}$ In general, a state lacks jurisdiction in the territory of another state. ${ }^{317}$ However, human rights obligations apply to extraterritorial actions when the state acts outside of its territory and exercises control over either territory or persons. ${ }^{318}$ Thus, human rights obligations will not apply to all acts of the state outside of its territory, but only to those acts where the state has sufficient control.

The Holy See objects to this interpretation. ${ }^{319}$ In its view, when a state's activities occur within another state's territory, then the former cannot be responsible because the territorial state must ensure human rights. ${ }^{320}$ For the Holy See to attempt to ensure human rights abroad would, in its view, amount to a violation of the right of a state against interference in its internal affairs. $^{321}$ This view, however, contradicts the Holy See's claim to exercise ecclesiastical penal jurisdiction over the territories of other states. ${ }^{322}$ Nonetheless, the Holy See maintains this approach to jurisdiction is new ${ }^{323}$

313. Second Reports of States Parties Due in 1997, supra note 16, ๆ 49.

314. See Concordat Between Holy See and Spain, supra note 60, art. XVI(7).

315. Additional examples include the right of the Holy See to demand certain states establish a state religion, otherwise favorably protect religious association and worship, recognize certain public holidays, and prohibit business activities on those days. See Concordat Between the Holy See and Spain, supra note 60 , arts. I-II, V.

316. See Armed Activities on the Territory of the Congo (Dem. Rep. Congo v. Uganda), Judgment, 2005 I.C.J. 168, 179 (Dec. 19); Legal Consequences of the Construction of a Wall in the Occupied Palestinian Territory, Advisory Opinion, 2004 I.C.J. 136, 1111 (July 9).

317. See Commc'n No. 48/1996, supra note 286; Jamaa v. Italy, 2012-II Eur. Ct. H.R. 97, para. 72; Ilaşcu v. Moldova, 2004-VII Eur. Ct. H.R. 179, para. 314; Loizidou v. Turkey, 310 Eur. Ct. H.R. (ser. A) at 23-24, para. 62 (1995); Al-Skeini v. United Kingdom, 2011-IV Eur. Ct. H.R. 99, paras. 132-36.

318. See Loizidou, 310 Eur. Ct. H.R paras. 62-63; Loizidou v. Turkey, 1996-VI Eur. Ct. H.R. 2217, para. 56; Cyprus v. Turkey, 2001-IV Eur. Ct. H.R. 1, para. 76; Drozd v. France, Appl. No. 12747/87, para. 91 (Eur. Ct. H.R., 1992), http://hudoc.echr.coe.int/eng?i=001-57774 [https://perma.cc/79FUQAJ2\#\{\%22itemid\%22:[\%22001-57774\%22]\}]; Ilaşcu, 2004-VII Eur. Ct. H.R. paras. 314-18.

319. Comments of the Holy See, supra note 28, para. 10.

320. See id. para. 12 .

321. See id. para. 3 .

322. See id. para. $9(\mathrm{~d})$.

323. See id. paras. $10,14$. 
and that, under the terms of the relevant treaties, it is not possible to have jurisdiction based on control. ${ }^{324}$

This position cannot be correct. When the CRC was adopted, jurisdiction in other human rights treaties had already been interpreted to include extraterritorial jurisdiction based on control. ${ }^{325}$ The Holy See must have been aware of this jurisprudence and the potential scope of its application by using the term "jurisdiction," rather than "territory." In fact, its awareness of this interpretation of jurisdiction is evidenced by its consistent acknowledgement that extraterritorial acts are covered by the CRC. Not only has the Holy See affirmed its responsibility to comply with the CRC when it acts extraterritorially in the Vatican City State, it also submits that it implements the CRC through individuals and actions worldwide. ${ }^{326}$ In fact, the Holy See routinely discusses its global activities as falling within its "jurisdiction." 327 The Holy See views its obligations under the CRC as existing in two forms: firstly, as implemented in the Vatican City and, secondly, as encouraged globally. ${ }^{328}$ However, the Holy See has documented its compliance with the CRC by identifying its worldwide actions and not mere encouragement, specifically by referring to church activities, practice and teaching globally. Therefore, this interpretation is not new, and the Holy See was aware of its scope when it initially adhered to and subsequently implemented the CRC.

\section{a. Jurisdiction Based on Control over Territory}

As noted above, not all acts undertaken outside of the state incur responsibility. Only those acts where the state has control can result in violations. The first possibility for extraterritorial control and jurisdiction is when the state exercises control over territory outside of the state's official territory. ${ }^{329}$ It is important to identify the area over which control is asserted,

324. See id. para. 10 .

325. See Commc'n No. 52/1979, supra note 249 (regarding extraterritorial application of the ICCPR based on control); X. v. United Kingdom, App. No. 7547/76, 12 Eur. Comm'n H.R. Dec. \& Rep. 73, 74 (1977) (regarding extraterritorial application of the ECHR based on control).

326. See Comments of the Holy See, supra note 28, paras. 3, 10(a).

327. See Agreement Between the Holy See and the Argentine Republic, supra note 48, art. I.

328. See List of Issues in Relation to the Second Periodic Report, supra note 9, 97.

329. See Armed Activities on the Territory of the Congo (Dem. Rep. Congo v. Uganda), Judgment, 2005 I.C.J. 168, 179 (Dec. 19); Legal Consequences of the Construction of a Wall in the Occupied Palestinian Territory, Advisory Opinion, 2004 I.C.J. 136, ๑q 109-11 (July 9); Commc'n No. 52/1979, supra note 249, \ 65; HRC, Obligation to Covenant, supra note 245; Commc'n No. 323/2007, supra note 240, ๆ 8.2; Commc'n No. 470/1991, supra note 249, ๆ 6.2; Commc'n No. 692/1996, supra note 249, ๆ 6.8; Commc'n No. 52/1979, supra note 249, ๆๆ 12.1-.3; Commc'n No. 56/1979, supra note 305, ๆๆ 10.1.3; HRC, Consideration of Reports 1995, supra note 249, 1 19; U.N., Comm. Against Torture, General Comment No. 2: Implementation of Article 2 by States Parties, $₫$ 16, U.N. Doc. CAT/C/GC/2 (Jan. 24, 2008) [hereinafter Comm. Against Torture, General Comment No. 2]; Loizidou, 310 Eur. Ct. H.R. (ser. 
which can vary in size. ${ }^{330}$ This test is the same test applied for actions on the high seas, where a state might exercise control over a ship by stopping or seizing it. ${ }^{331}$

Arising out of a large number of cases before various human rights tribunals and bodies, the test for extraterritorial jurisdiction is de facto control, as opposed to de jure authority. ${ }^{332}$ In the latter, the state has the right to control, but in the former, the question is whether the state actually controls the territory in fact. Certainly in many cases, the state will have de jure authority in addition to de facto control, for example, ships and aircraft, ${ }^{333}$ diplomatic premises, ${ }^{334}$ or military bases/detention centers. ${ }^{335}$ But the test for jurisdiction is whether the state is in fact controlling the territory. ${ }^{336}$ For example, a state can acquire control through military or police presence or occupation, ${ }^{337}$ but does not acquire control by bombing an

A) para. 62; Loizidou v. Turkey, 1996-VI Eur. Ct. H.R. 2217, para. 56; Cyprus v. Turkey, 2001-IV Eur. Ct. H.R. 1, paras. 77-78; Jamaa v. Italy, 2012-II Eur. Ct. H.R. 97, paras. 72-75, 79-82; Banković v. Belgium, 2001-XII Eur. Ct. H.R. 333, paras. 70-71; Issa v. Turkey, App. No. 31821/96, para. 69 (Eur. Ct. H.R., 2004), http://hudoc.echr.coe.int/eng?i=001-67460 [https://perma.cc/Z2SC-J23W]; Medvedyev v. France, 2010-III Eur. Ct. H.R. 61, para. 64; Saldaño v. Argentina, Inter-Am. Comm'n H.R., Report No. 38/99, OEA/Ser.L/V/II.95 doc.7 rev. (1998); Coard v. United States, Case 10.951, Inter-Am. Comm'n H.R., Report No. 109/99, OEA/Ser.L/V/II.106 doc. 3 rev. (1999).

330. See Öcalan v. Turkey, App. No. 46221/99, para. 93 (Eur. Ct. H.R., 2003), http:// hudoc.echr.coe.int/eng? $\mathrm{i}=001-60979$ [https://perma.cc/G6SE-8H4K] (describing how determining the extraterritorial jurisdiction of Turkey in an international terminal of a Nairobi airport had implications on an applicant's capture and detainment).

331. See Medvedyev, 2010-III Eur. Ct. H.R. paras. 62-67; Jamaa, 2012-II Eur. Ct. H.R. paras. 7778; Comm. Against Torture, General Comment No. 2, supra note 329, \ 16.

332. See Jaloud v. Netherlands, 2014-VI Eur. Ct. H.R. 229, para. 142; Al-Skeini v. United Kingdom, 2011-IV Eur. Ct. H.R. 99, paras. 132-136; Banković, 2001-XII Eur. Ct. H.R. paras. 59-61, 67-71; Medvedyev, 2010-III Eur. Ct. H.R. para. 67; Comm. Against Torture, General Comment No. 2, supra note 329, ๆ 16. But see Alejandre Jr. v. Cuba, Case 11.589, Inter-Am. Comm'n H.R., Report No. 86/99, OEA/Ser.L/V/II.106, doc. 3 rev. I 23 (1999) ("[I]n certain cases, the exercise of its jurisdiction over extraterritorial events is not only consistent with but required by the applicable rules."); Saldaño, InterAm. Comm'n H.R. ๆฯ 15-22 (establishing a lower level of control required for extraterritorial jurisdiction to apply).

333. See Assanidze v. Georgia., 2004-II Eur. Ct. H.R. 221, para. 137.

334. See Commc'n No. 106/1981, supra note 297; Comm. Against Torture, General Comment No. 2, supra note 329, I 16; M. v. Denmark, App. No. 17392/90, 73 Eur. Comm'n H.R. Dec. \& Rep. 193, 196 (1992); X v. Germany, App. No. 1611/62, 1965 Y.B. Eur. Conv. on H.R. 158, 168 (Eur. Comm'n on H.R.); X. v. United Kingdom, App. No. 7547/76, 12 Eur. Comm'n H.R. Dec. \& Rep. 73, 74 (1977).

335. See Comm. Against Torture, General Comment No. 2, supra note 329, ๆ 16; Al-Saadoon v. United Kingdom, App. No. 61498/08, paras. 85-89 (Eur. Ct. H.R., 2009), http://hudoc.echr.coe.int/ eng? $\mathrm{i}=001-93398$ [https://perma.cc/P67Z-STSW].

336. See HRC, Obligation to Covenant, supra note 245; Geneva Convention Relative to the Protection of Civilian Persons in Time of War, art. 2, Aug. 12, 1949, 75 U.N.T.S. 287; Jamaa, 2012-II Eur. Ct. H.R. para. 73; Commc'n No. 323/2007, supra note 240, ๆ 8.2.

337. See Armed Activities on the Territory of the Congo (Dem. Rep. Congo v. Uganda), Judgment, 2005 I.C.J. 168, 179 (Dec. 19); Legal Consequences of the Construction of a Wall in the Occupied Palestinian Territory, Advisory Opinion, 2004 I.C.J. 136, ๆ甲 107-11 (July 9); Legal Consequences for 
area, ${ }^{338}$ having incidental military operations in the region, ${ }^{339}$ or having a diffuse military presence. ${ }^{340}$ Similarly, it does not lose control, and thus jurisdiction, when it permits another state's armed forces to have operational management over its forces, provided the state still retains control over the area. $^{341}$ Thus, the threshold level of control is high. ${ }^{342}$ While there is a presumption that a state retains jurisdiction over its lawful territory even during situations of military occupation, the reverse is not true: states are not presumed to have control when they act extraterritorially. ${ }^{343}$ Extraterritorial jurisdiction will only occur in "exceptional circumstances." 344

Now we can apply this rule on de facto territorial control to the Holy See. Certainly, the Holy See controls the territory of the Vatican City through its de jure and de facto governance of that state. The Holy See has argued consistently that its CRC obligations apply "first and foremost" within the Vatican City, ${ }^{345}$ so this jurisdiction is not in dispute. As discussed above, the Holy See exercises police powers within the Vatican City, and an internal justice system with coercive powers. While the Holy See lacks a military in the traditional sense, it does have police and the Swiss Guard who, in a sense "occupy" the Vatican, though it is not a belligerent occupation, of course.

States of Continued Presence of South Africa in Namibia Notwithstanding Security Council Resolution 276, Advisory Opinion, 1971 I.C.J. 16, ๆ 118 (June 21); HRC, Obligation to Covenant, supra note 245, ๆ 10; Comm. Against Torture, General Comment No. 2, supra note 329, ๆ 16; Banković, 2001-XII Eur. Ct. H.R. para. 71; Loizidou v. Turkey, 310 Eur. Ct. H.R. (ser. A) at 23-24, para. 62 (1995); Loizidou v. Turkey, 1996-VI Eur. Ct. H.R. 2217, para. 56; Al-Skeini, 2011-IV Eur. Ct. H.R. paras. 132, 136; AlSaadoon, App. No. 61498/08 paras. 85-89.

338. See Banković, 2001-XII Eur. Ct. H.R. paras. 74-75.

339. See Issa v. Turkey, App. No. 31821/96, paras. 73-75, 82 (Eur. Ct. H.R., 2004), http:// hudoc.echr.coe.int/eng?i=001-67460 [https://perma.cc/VQC2-ZYUA].

340. See Hess v. United Kingdom, App. No. 6231/73, 2 Eur. Comm'n H.R. Dec. \& Rep. 72, 73-74 (1975); Hussein v. Albania, App. No. 23276/04, 42 Eur. H.R. Rep. 223, 224-25 (2006).

341. Jaloud v. Netherlands, 2014-VI Eur. Ct. H.R. 229, paras. 142-43.

342. See id.; Al-Skeini, 2011-IV Eur. Ct. H.R. paras. 132-36; Banković, 2001-XII Eur. Ct. H.R. paras. 59-61, 67; Medvedyev v. France, 2010-III Eur. Ct. H.R. 61, para. 64; Comm. Against Torture, General Comment No. 2, supra note 329, 16. But see Alejandre Jr. v. Cuba, Case 11.589, Inter-Am. Comm'n H.R., Report No. 86/99, OEA/Ser.L/V/II.106, doc. 3 rev. ๆๆ 23-25 (concluding Cuba exercised extraterritorial jurisdiction when Cuban Air Force pilots, after receiving authorization, shot down victims flying civilian aircraft in international airspace) (1999); Saldaño v. Argentina, Inter-Am. Comm'n H.R., Report No. 38/99, OEA/Ser.L/V/II.95 doc.7 rev. \ๆ 15-21 (1998) (establishing a lower level of control required for extraterritorial jurisdiction to apply).

343. See Mozer v. Moldova, App. 11138/10, paras. 97-98 (Eur. Ct. H.R. 2016), http://hudoc.echr.coe.int/eng?i=001-161055 [https://perma.cc/AK4X-XVUC]; Gentilhomme v. France, App. Nos. 48205/99, 48207/99, \& 48209/99, para. 16 (Eur. Ct. H.R., 2002), http://hudoc.echr.coe.int/eng?i=001-65008 [https://perma.cc/7QZA-LBKW]; Assanidze v. Georgia, 2004-II Eur. Ct. H.R. 221, para. 137; Banković, 2001-XII Eur. Ct. H.R. paras. 59-61.

344. See Mozer, App. 11138/10, paras. 97-98; Al-Skeini, 2011-IV Eur. Ct. H.R. para. 132; Chagos Islanders v. United Kingdom, App. 35622/04, 56 Eur. H.R. Rep. 173, para. 70 (2013).

345. See Comments of the Holy See, supra note 28. 
The Holy See has already admitted and affirmed that its activities within the Vatican City must comply with the CRC. It submits the practice of acts within Vatican City in the compliance reports to the CRC Committee and the CERD committee. ${ }^{346}$ In addition, the Holy See accepts that it has jurisdiction over non-Vatican City entities within the Vatican City, ${ }^{347}$ so it appears to accept that control over territory imposes a wide degree of jurisdiction.

As for loss of control within the Vatican City, in certain instances Italy will exercise jurisdiction. Under the Lateran Accords, although Italy ceded sovereignty over St. Peter's Square as a part of the Vatican City, Italy retained police authority in the Square, but only as far as the steps of the Basilica. ${ }^{348}$ Italian police forces can be invited into the Basilica and Square by the Holy See, though they can also be requested to withdraw. ${ }^{349}$

Continuing with the possibility that the Holy See exercises control over territory, the next question is whether the Holy See exerts extraterritorial jurisdiction in any territory aside from the Vatican City. The Holy See does operate diplomatic missions abroad, and the case law is very clear that those areas do fall within effective control. In addition, the Holy See has a governance role, termed "jurisdiction", regarding "conservation and administration" over several "Holy Places" in Israel. ${ }^{350}$ In addition, the Holy See exercises religious oversight "jurisdiction" over military chaplains who practice the faith in foreign armed forces, ${ }^{351}$ although the diffuse activities of chaplains alone would likely not suffice to give rise to jurisdiction.

346. See CERD, Concluding Observations 2016, supra note 145, ๆ 5 ("The Committee welcomes the efforts made by the State party to implement the Committee's previous concluding observations to bring its legislation into line with the requirements of the Convention . . . in particular the promulgation in July 2013 of Vatican City State Law No. VIII . . . and Law No. IX, containing amendments to the criminal code and the criminal procedure code.").

347. See U.N., Comm. on the Elimination of Racial Discrimination, Consideration of Reports Submitted by States Parties Under Article 9 of the Convention, Concluding Observation of the Committee on the Elimination of Racial Discrimination: Holy See, ๆ 5, U.N. Doc. CERD/C/304/Add.89 (May 1, 2001) [hereinafter CERD, Consideration of Reports 2001] (citing practices by Vatican Radio, Osservatore Romano, and Pontifical Council for the Pastoral Care of Migrants and Itinerant People); Comm. on the Elimination of Racial Discrimination, Rep. of the Committee on the Elimination of Racial Discrimination, qๆ 280-81, U.N. Doc. A/48/18 (Sept. 15, 1993) [hereinafter CERD Report 1993] ("Pontifical Council on migrants and displaced persons and Catholic aid agencies... . Pontifical Commission for religious relations with Judaism and the Pontifical Commission for religious relations with Muslims.”).

348. See Lateran Accords, supra note 9, art. 3.

349. See id.

350. See Agreement on Matters of Common Interest in the Holy Land, Holy See-Spain, arts. 1-2, Dec. 21, 1994, 1890 U.N.T.S. 129.

351. See Agreement Concerning Religious Assistance to the Armed Forces and Concerning the Military Service of Members of the Clergy and Members of Religious Orders, Holy See-Spain, Annex I, arts. I, III, IV, Jan. 3, 1979, 1154 U.N.T.S. 55 [hereinafter Agreement Concerning Religious Assistance to the Armed Forces]. 
Churches are a more difficult question. The Holy See expressly rejects that it has the "capacity or legal obligation to impose [CRC] principles upon the local Catholic churches and institutions present on the territory of other States and whose activities abide with national laws," ${ }^{352}$ because it does not exercise effective control over local churches. ${ }^{353}$ Nonetheless, a select number of specially designated churches do fall within the Holy See's control, and the Holy See expressly acknowledges that it has jurisdiction over them. ${ }^{354}$ As a part of the Lateran Accords, the Holy See gained extraterritorial rights over a number of churches and other buildings in and around Rome, yet outside of the Vatican City State territory, ${ }^{355}$ such as Castel Gandolfo and the Basilicas of St. John Lateran, Saint Mary Major and St. Paul, among other properties. ${ }^{356}$ These areas do not form part of the state of the Vatican City, but are comparable to embassies. In addition, under the Lateran Accords, the Holy See enjoys extraterritorial rights over any church in Italy when the Pope is present in the church for religious services and the building is not open to the public. ${ }^{357}$ As they can be assimilated to embassies, the Holy See also has effective control over them.

Other local churches not expressly covered in the Lateran Accords do not have that same relationship with the Holy See, but the question for human rights law is one of de facto control. The Holy See has the power to establish or abolish churches ${ }^{358}$ and similar institutes of consecrated life. ${ }^{359}$ In rare cases, churches enjoy some kinds of local immunity ${ }^{360}$ and inviolability. ${ }^{361}$ Churches fall under the authority of their bishop, his "jurisdiction," ${ }^{362}$ and bishops are, in turn, appointed by and answer to the Holy See. Since the test for control is de facto, not whether an entity has any particular legal or religious status, it does not on its face appear to be an issue of whether control is religious or physical, as long as the entity can in fact control the space.

352. Comments of the Holy See, supra note 28, para. 3.

353. See List of Issues in Relation to the Second Periodic Report, supra note 9, 154 ("The Holy See does not exercise effective control over the local activities of Catholic institutions around the world, which operate in accordance with their own status in canon law and the laws of the respective State in which they operate.").

354. See Agreement Concerning Legal Matters, supra note 301, art. I(1) ("The Spanish State recognizes the right of the Catholic Church to carry on its apostolic mission and guarantees it the free and public exercise of the activities proper to it and in particular those of cult, jurisdiction and teaching.").

355. See Lateran Accords, supra note 9, arts. 13-16.

356. See id.

357. See id. art. 15 .

358. 1983 CODE cs.372-73, 433.

359. See id. cs.582-84, 591.

360. See Concordat with Latvia, supra note 310, art. 15.

361. See Concordat Between the Holy See and Spain, supra note 60, art. XXII.

362. See Convention Regarding Missions, Colom.-Holy See, art. II, May 5, 1928, 79 L.N.T.S. 157. 
However, the Holy See does not appear to truly control the space in these churches to the degree necessary to trigger jurisdiction over the area.

Aside from the Vatican City, embassies and certain designated extraterritorial buildings and churches, there may be other places over which the Holy See exercises sufficient control. For example, the Holy See has "authority and responsibility under canon law" for educational activities in Catholic schools worldwide pursuant to concordats, though the schools are administered "pursuant to the laws of the respective States in which they operate." "363 However, given the more vulnerable position of children in school, it is not difficult to see how a school administration might exert sufficient physical control of the institution to amount to territorial jurisdiction, perhaps even more so if it is a boarding school. It is not a matter of whether the state where the school is located has a legal right to exercise jurisdiction, but rather whether the Holy See is in de facto control.

b. Jurisdiction Based on Control over Persons

The other way for the Holy See to exercise jurisdiction, though, would be where it has effective control over certain victims specifically, not over the territory generally. ${ }^{364}$ Under human rights law, de facto control over the territory is not necessary where the state has control over the victim. In cases of territorial control, the state would be responsible for all acts in the territory regardless of control over the victim. Under personal control, the state would only be responsible for the violations against the victim. In this scenario, the state does not have control over the land, but asserts control over an individual. This form of control resulting in extraterritorial jurisdiction does not relate to what the state does within a space, but instead what it does to a person. This section will also consider some of the same acts discussed above and analyze control over the persons in the alternative to acts with extraterritorial effect or acts controlling territory.

i. Attribution of the Acts of State Officials

Under the alternative of jurisdiction based on control over a person, and because of its focused nature, we need to ensure that the individual asserting control over the victim is indeed a state agent. This finding is necessary in situations of territorial control too, but there it is usually easy to identify the police or military of a state. In the case of one person or few people being controlled, we need to be particularly careful to identify the relationship between the actor and the state.

363. Second Reports of States Parties Due in 1997, supra note 16, $\uparrow 32$; see also id. $\uparrow 75$ (regarding similar language for healthcare facilities).

364. See HRC, Consideration of Reports 1995, supra note 249, ๆ 19. 
The first possibility is that the actor is a state agent, organ or official who is acting extraterritorially with control over a victim. ${ }^{365}$ This situation includes actions by military, ${ }^{366}$ police,${ }^{367}$ border control, ${ }^{368}$ and diplomatic or consular officers, ${ }^{369}$ where they are not otherwise controlling territory.

Turning to the Holy See, we need to determine which persons are, or are assimilated to, state officials. The Holy See defines its public officials as: "papal legates and diplomatic personnel of the Holy See" in addition to "members, officials and personnel of the various organs of the Roman Curia and of the Institutions connected to it." $" 370$ These are also persons with a papal appointment. ${ }^{371}$ However, Pope Francis has stated that state officials also include "those persons who serve as representatives, managers or directors, as well as persons who even de facto manage or exercise control over the entities directly dependent on the Holy See and listed in the registry of

365. See Military and Paramilitary Acts in and Against Nicaragua (Nicar. v. U.S.), Judgment, 1986 I.C.J. 14, 9 ๆ 14, 65 (June 27) (noting that a State must exert "effective control" over operatives in foreign territory for the United States to incur responsibility); Commc'n No. 57/1979, supra note 299; U.N., Human Rights Comm., Consideration of Reports Submitted by States Parties Under Article 40 of the Covenant, Concluding Observations of the Human Rights Committee: Belgium, U.N. Doc. CCPR/C/79/Add.99 (Nov. 19, 1998); U.N., Human Rights Comm., Concluding Observations of the Human Rights Committee: Germany, U.N. Doc. CCPR/CO/80/DEU (May 4, 2004); Al-Skeini v. United Kingdom, 2011-IV Eur. Ct. H.R. 99, paras. 132, 136; Jaloud v. Netherlands, 2014-VI Eur. Ct. H.R. 229, paras. 151-53; Pisari v. Moldova, App. No. 42139/12, para. 33 (Eur. Ct. H.R., 2015), http://hudoc.echr.coe.int/eng?i=001-153925 [https://perma.cc/Q6DX-7PXF]; Issa v. Turkey, App. No. 31821/96, para. 71 (Eur. Ct. H.R., 2004), http://hudoc.echr.coe.int/eng?i=001-67460 [https://perma.cc/ QY46-3S5P]; Jamaa v. Italy, 2012-II Eur. Ct. H.R. 97, para. 74; Sánchez Ramirez v. France, App. No. 28780/95, 86-A Eur. Comm'n H.R. Dec. \& Rep. 155, 161-62 (1996); Öcalan v. Turkey, 2005-IV Eur. Ct. H.R. 131, paras. 13-60; Haitian Ctr. for Human Rights v. United States, Case 10.675, Inter-Am. Comm'n H.R., Report No. 51/96, OEA/Ser.L/V/II.95, doc. 7 rev. 157 (1997).

366. See HRC, Obligation to Covenant, supra note 245, ๆ 10; Comm. Against Torture, General Comment No. 2, supra note 329, ๆ 16; Al-Saadoon v. United Kingdom, App. No. 61498/08, paras. 8589 (Eur. Ct. H.R., 2009), http://hudoc.echr.coe.int/eng?i=001-93398 [https://perma.cc/9AKQ-PSYS]; $\mathrm{Al}$ Skeini, 2011-IV Eur. Ct. H.R. paras. 132, 136; Al-Jedda v. United Kingdom, 2011-IV Eur. Ct. H.R. 305, paras. 85-86; Medvedyev v. France, 2010-III Eur. Ct. H.R. 61, para. 67; Jaloud v. Netherlands, 2014-VI Eur. Ct. H.R. 229, paras. 140-53; OAU Res. No. 2/11, Situation of Detainees at Guantanamo Bay (July 22, 2011) [hereinafter Situation of Detainees at Guantanamo Bay]; U.S. Military Activity in Panama, Case 10.573, Inter-Am. Comm'n. H.R., Report No. 31/93, OAE/Ser.L/V.85, doc. 9 rev. (1993).

367. See Commc'n No. 52/1979, supra note 249, \12.2; Commc'n No. 56/1979, supra note 305, ๆๆ $10.1-.2$.

368. See X \& Y v. Switzerland, App. Nos. 7289/75 \& 7349/76, 9 Eur. Comm'n H.R. Dec. \& Rep. 57, 71-73 (1977); R v. Immigration Officer at Prague Airport [2004] UKHL 55, [2005] 2 AC (HL) 38 (appeal taken from Eng.).

369. See Commc'n No. 106/1981, supra note 297, ๆ 5; El Ghar v. Libyan Arab Jamahiriya, U.N. Human Rights Comm., Commc'n No. 1107/2002, ๆ 8, U.N. Doc. CCPR/C/82/D/1107/2002 (Nov. 15, 2004) [hereinafter Commc'n No. 1107/2002]; Varela Nunez v. Uruguay, U.N. Human Rights Comm., Commc'n No. 108/1981, ๆๆ 9.1-.2, U.N. Doc. CCPR/C/19/D/108/1981 (July 22, 1983) [hereinafter Commc'n No. 108/1981]; Assanidze v. Georgia, 2004-II Eur. Ct. H.R. 221, para. 137 (2004).

370. Apostolic Letter Issued Motu Proprio, supra note 129, para. 3(a).

371. See 1983 CODE c.361. 
canonical juridical persons;", 372 as well as "any other person holding an administrative or judicial mandate in the Holy See, permanent or temporary, paid or unpaid, irrespective of that person's seniority."373 The Holy See accepts that it has jurisdiction over the acts of certain state officials abroad, where those officials exert control over other persons. Specifically, the Holy See accepts that acts by diplomatic personnel abroad could fall within its jurisdiction, ${ }^{374}$ although it expressly rejects that other Catholic personnel are within its jurisdiction. ${ }^{375}$

While it is fairly straightforward to identify diplomats of the Holy See, we can recall that their duties are not entirely temporal and that they are also clergy with a religious mission and church governance function. Canon law expressly includes both diplomats and religious representatives aboard under the same functional appointment. ${ }^{376}$ This dual spiritual and temporal mission means that the acts of some clergy are assertions of the Holy See's jurisdiction.

However, it is more challenging to make the case that clergy falling outside of the Francis definition can exercise jurisdiction of the Holy See. The Human Rights Committee has concluded that "bishops and major superiors of religious institutes do not act as representatives or delegates of the Roman Pontiff." 377 This is correct in that these officials are not diplomats representing the Pope, but they may nonetheless still be Holy See officials for the purposes of human rights law. There are a number of reasons to support the conclusion that these clergy constitute de facto officials. The communications between bishops (who are not diplomats) and the Holy See, are inviolable and protected by international law. ${ }^{378}$ While this provision does not of its own force transform all bishops into diplomats pursuant to the Vienna Convention on Diplomatic Relations, it does confirm communications between bishops and the Holy See are official acts of the Holy See as an international legal person, and not those of the Vatican City State or solely of the Church. In addition, international law protects the rights of episcopates to call for orders, congregations and priests to serve them, and certain governments are obliged to permit these people entry and sojourn in their territories. ${ }^{379}$ Where a member of Catholic clergy or religious order is

372. Apostolic Letter Issued Motu Proprio, supra note 129, para. 3(c).

373. Id. at $3(\mathrm{~d})$.

374. See Comments of the Holy See, supra note 28, para. 3.

375. Id.

376. 1983 CODE c.362.

377. Comments of the Holy See, supra note 28, para. 4.

378. See Agreement Between the Holy See and the Argentine Republic, supra note 48, art. IV.

379. Id. art. V. 
charged with a criminal offense, there is an equivalent to the consular notification obligation for nationals and their respective states of nationality, ${ }^{380}$ and courts may be obliged to inform and seek consent of the Holy See for prosecution. ${ }^{381}$ The members of Catholic clergy and religious orders may also be exempted from giving evidence on matters linked to their ministry, ${ }^{382}$ taxes, ${ }^{383}$ military service, ${ }^{384}$ and public duties, ${ }^{385}$ and may benefit from a visa regime comparable to diplomats. ${ }^{386}$ In addition to these quasidiplomatic benefits, many non-diplomatic clergy are used as de facto diplomats. As discussed above, the Holy See uses both, official diplomats and unofficial interlocutors, in the form of its clergy. Non-diplomatic bishops have been involved in making diplomatic representations. ${ }^{387}$ Given the enjoyment of these benefits, clergy outside of the broader Francis definition might still be assimilated to diplomats or state officials.

\section{ii. Attribution of the Acts of Non-Officials of the State}

In addition to the officials mentioned above, other individuals might also implicate the Holy See. Under human rights law, individuals who do not qualify as state officials, but whose actions are otherwise attributable to the state, can exercise sufficient control over individuals to trigger jurisdiction. ${ }^{388}$ Again, the test is de facto effective control over the individual's actions. ${ }^{389}$ The threshold of control remains high, ${ }^{390}$ but for purposes of jurisdiction, it may not be as high as under the normal application of the rules on responsibility. Specifically, control could be direct or

380. See Agreement Concerning Mutual Relations, supra note 48, art. II.

381. See Concordat Between the Holy See and Spain, supra note 60, art. XVI(1)-(4).

382. See Agreement Between the Italian Republic and the Holy See, supra note 34, art. 4; Agreement Concerning Mutual Relations, supra note 48, art. II(3).

383. See Lateran Accords, supra note 9, art. 17; Concordat Between the Holy See and Spain, supra note 60 , art. $\mathrm{XX}(1)$

384. See Concordat Between the Holy See and Spain, supra note 60, art. XV; Agreement Between the Italian Republic and the Holy See, supra note 34, art. 4(1); Concordat with Latvia, supra note 310, art. 9; Agreement Concerning Religious Assistance to the Armed Forces, supra note 351, art. VI, Final Protocol (3).

385. See Concordat Between the Holy See and Spain, supra note 60, art. XIV.

386. Agreement Between the Holy See and the Argentine Republic, supra note 48, art. V.

387. Jesuit Scholar Discusses Christian Support, supra note 109.

388. See Commc'n No. 52/1979, supra note 249, ๆๆ 12.1-.3; Ilaşcu v. Moldova, 2004-VII Eur. Ct. H.R. 179, paras. 390-94.

389. See Jaloud v. Netherlands, 2014-VI Eur. Ct. H.R. 229, paras. 151-52; Öcalan v. Turkey, App. No. 46221/99, para. 93 (Eur. Ct. H.R., 2003), http://hudoc.echr.coe.int/eng?i=001-60979 [https://perma .cc/Q8R6-ND6F]; Ilaşcu, 2004-VII Eur. Ct. H.R. 179, paras. 312-14.

390. See Banković v. Belgium, 2001-XII Eur. Ct. H.R. 333, paras. 61, 67. 
indirect, ${ }^{391}$ provided the state has "significant and decisive influence over the [actor] ... by virtue of the military, political, financial and other support given to it." 392 That being said, it would not suffice when the sponsoring state merely appoints a judge or other officer in a foreign state without retaining some control over that person. ${ }^{393}$ All the cases of control through support focus on exercising jurisdiction in a break-away, separatist, unrecognized or quasi-state, where the local regime might not continue without external support. $^{394}$

The question for the Holy See is whether it similarly controls or supports any actors in a foreign territory. We have already concluded that it does in the Vatican City State. If the clergy do not qualify as de facto diplomats, they could alternatively qualify as individuals under the control of the Holy See. In fact, this possibility appears to be met because the Holy See does assert sufficient control over clergy. While clergy must comply with local laws, ${ }^{395}$ they must also give an oath of full obedience to the Pope. $^{396}$

The Holy See argues that obedience is a religious obligation, not a matter of governance. ${ }^{397}$ It argues that it only has control over the doctrine. ${ }^{398}$ Firstly, that statement overlooks the multifaceted modes of control and

391. See Loizidou v. Turkey, 310 Eur. Ct. H.R. (ser. A) at 23-24, para. 62 (1995); Comm. Against Torture, General Comment No. 2, supra note 329, 916.

392. Chiragov v. Armenia, 2015-III Eur. Ct. H.R. 135, para. 186; see also Application of the Int'l Convention on the Elimination of All Forms of Racial Discrimination (Geor. v. Russ.), 2008 I.C.J. 353, qศ 65-67, 149 (Oct. 15); Cyprus v. Turkey, 2001-IV Eur. Ct. H.R. 1, paras. 77-78; Ilaşcu, 2004-VII Eur. Ct. H.R. paras. 8, 390-94; Issa v. Turkey, App. No. 31821/96, para. 74 (Eur. Ct. H.R., 2004), http://hudoc.echr.coe.int/eng?i=001-67460 [https://perma.cc/8RUK-LL5K].

393. See Drozd v. France, Appl. No. 12747/87, para. 96 (Eur. Ct. H.R., 1992), http://hudoc.echr.coe.int/eng?i=001-57774 [https://perma.cc/79FU-QAJ2\#\{\%22itemid\%22:[\%22001$57774 \% 22]\}]$.

394. See, e.g., Geor. v. Russ., 2008 I.C.J. qฯ 65-67, 149; Cyprus, 2001-IV Eur. Ct. H.R. paras. 7778; Loizidou v. Turkey, 1996-VI Eur. Ct. H.R. 2217, para. 52; Chiragov, 2015-III Eur. Ct. H.R. para. 186; Ilaşcu, 2004-VII Eur. Ct. H.R. paras. 392, 454; Issa, App. No. 31821/96 para. 74.

395. See, e.g., Concordat with Latvia, supra note 310, art. 5.

396. For more detail on the obligations to show reverence to the Pope, see 1983 CODE cs.273, 380; $590, \S \S 1-2$.

397. See Comments of the Holy See, supra note 28 , para. 7 ("The profundity of confusion regarding the nature of the Holy See, its internal legal order as well as its international legal personality, is fully revealed, for example, in Concluding Observation para. $8 \ldots$ when 'religious obedience', in canons 331 and 590 of the Codex Iuris Canonici (CIC), is interpreted to construct a new form of 'ecclesial governance,' where the Holy See is required to control the daily activities of clerics, religious and laypersons, living in the territories of sovereign States.") (citations omitted).

398. See id. para. 9(c) ("That the 'religious obedience' of Bishops and religious Superiors concerns the unity of the doctrine of the Catholic faith and of the Catholic Church, founded and constituted as a society by Jesus Christ based on the communion of faith, sacraments and discipline, which are freely adhered to by members of the faithful ....") (citations omitted). 
focuses only on one aspect of control, the religious relationship. As far as political and governance control, the Holy See's role is significant. At a minimum, a priest who refuses to obey the Holy See loses his appointment and career. ${ }^{399}$ The Holy See has the exclusive authority to establish and modify ecclesiastical districts, ${ }^{400}$ though the Holy See may have an obligation to consult with the government of the state in which those districts exist. ${ }^{401}$ In addition, the Holy See may appoint archbishops and bishops often without the need for consultation with the local government. ${ }^{402}$ Where such appointment is discharged by the conference of Bishops, the Holy See retains the right of approval. ${ }^{403}$ The Holy See is not, however, just an appointing authority. Clergy must report to the Holy See, ${ }^{404}$ and the Holy See retains control over the clergy through supervision, ${ }^{405}$ even in matters of "internal

399. See, e.g., Conor Gaffey, Pope Francis Demands Obedience in Strict Ultimatum to Unruly Nigerian Priests, NEWSWEEK (June 12, 2017, 5:47 AM), https://www.newsweek.com/pope-francisnigeria-christianity-catholic-church-obedience-624230 [https://perma.cc/Z76S-SFH4] (explaining Pope Francis' demand that every priest of the Ahiara diocese must "clearly manifest total obedience to the pope and . . . be willing to accept the bishop whom the pope sends and has appointed"' or risk suspension from duties and loss of current office); Daniel Burke, Pope Francis Fires Bishop of Memphis, CNN (Oct. 25, 2018, 6:20 PM), https://edition.cnn.com/2018/10/24/us/memphis-bishop-pope/index.html [https://perma.cc/Q28P-SHJX] (noting the removal of a Bishop as the result of a Vatican investigation into the Bishop's reassignment of a large number of priests to new parishes and his hiring of a Canadian priest to a prominent post); Holy See Press Office, Comunicato della Congregazione per la Dottrina della Fede [Communique of the Congregation for the Doctrine of the Faith], Holy SEE (Feb. 16, 2019), http://press.vatican.va/content/salastampa/it/bollettino/pubblico/2019/02/16/0133/00272.html\#en [https://perma.cc/VX9X-WEBX] (announcing the decision of the Congregation for the Doctrine of the Faith - a Holy See organ - expelling Cardinal emeritus Theodore McCarrick from the clergy).

400. Agreement Between the Holy See and the Argentine Republic, supra note 48, art. II; Concordat Between the Holy See and Spain, supra note 60, art. XI.

401. See, e.g., Agreement Between the Holy See and the Argentine Republic, supra note 48, art. II.

402. 1983 CODE cs.232, 377-78; see also Agreement Between the Holy See and the Republic of Latvia, supra note 62, art. 4; Concordat Between the Holy See and Spain, supra note 60, art. VII; Establishment of a Military Vicariate with the Philippines, supra note 177, art. I(2); Agreement Between the Holy See and the Argentine Republic, supra note 48, art. III; Agreement Concerning Mutual Relations, supra note 48, art. I(1); Fundamental Agreement Between the Holy See and the State of Israel, supra note 39, art. 3, § 2; Acuerdo Entre la Santa Sede y la República de Venezuela para la Creacion de un Ordinariato Militar, Holy See-Venez., art. I, Nov. 24, 1994, 87 Acta Apost. Sedis 1092 [hereinafter Agreement Between the Holy See and the Republic of Venezuela for the Creation of a Military Ordinariate]; Holy See and Republic of Croatia Agreement 1996, supra note 61, art. 6.

403. 1983 CODE c. $242, \S 1$.

404. Id. c. $399, \S 1 ; i d$. c.592, § 1 .

405. See id. cs.377, $\S \S 1-2,5,378$; Agreement Between the Holy See and the Argentine Republic, supra note 48, art. III; Concordat with Latvia, supra note 310, art. 3; Holy See and Republic of Croatia Agreement 1996, supra note 61, art. 6; Agreement Between the Holy See and the Republic of Venezuela for the Creation of a Military Ordinariate, supra note 48, arts. I, VII; Fundamental Agreement Between the Holy See and the State of Israel, supra note 39, art. 3, § 2; Convention Entre le Saint-Siége et la République de Côte d'Ivoire Concernant la "Fondation Internationale Notre-Dame de la Paix de Yamoussoukro," arts. I-II, May 20, 1992, 84 Acta Apost. Sedis 840. 
governance and discipline, ${ }^{, 406}$ and tasks undertaken in a personal capacity. ${ }^{407}$ This supervision includes punishment for offences and maladministration. ${ }^{408}$ In addition, the Holy See generally asserts its jurisdiction over bishops. ${ }^{409}$ While the Holy See does not assert a right to speak at a conference of bishops (unless discussing a matter of "international character" ${ }^{410}$ ), it does determine the topics available for discussion ${ }^{411}$ and must approve all decisions of the conference. $^{412}$ Finally, the governance system is hierarchical and monarchical. ${ }^{413}$ The Holy See holds all legislative, executive and judicial authority, ${ }^{414}$ with the Pope being the organ that ultimately exercises the supreme power in the church. ${ }^{415}$ Through his role in the Holy See, he has ultimate power over all churches and groups of churches, ${ }^{416}$ and forms the legitimate basis for the authority of bishops to whom authority is delegated. ${ }^{417}$ At the end of the day, the Pope can always remove cases from

406. 1983 CODE c.593, see also id. c. $242, \S 1$.

407. See id. cs.285(1)-(4), 286, 289.

408. See Johannes Baptist Sägmüller, Ecclesiastical Jurisdiction, in 8 THE CATHOLIC ENCYCLOPEDIA: AN INTERNATIONAL WORK OF REFERENCE ON THE CONSTITUTION, DOCTRINE, Discipline, AND History OF THE CATHOLIC CHURCH 569 (Charles G. Herbermann et al. eds., 1913).

409. See Concordat with Latvia, supra note 310, art. 3.

410. 1983 CODE c. $459, \S 2$.

411. See id. c. $455, \S 1$.

412. See id. cs. $242, \S 1,455, \S 2,456$.

413. See Joseph Clifford Fenton, Episcopal Jurisdiction and the Roman See, 120 AM. ECCLESIASTICAL REV. 337, 342 (1949) (“[T]he Catholic Church is essentially hierarchical as well as monarchical in its construction.").

414. 1983 CoDE cs.331, 1442; see also Robert Ombres, Canon Law and Theology, 14 ECCLESIASTICAL L.J. 164, 166, 167 (2012).

415. See 1983 CODE c.331 ("The bishop of the Roman Church, in whom continues the office given by the Lord uniquely to Peter, the first of the Apostles, and to be transmitted to his successors, is the head of the college of bishops, the Vicar of Christ, and the pastor of the universal Church on earth. By virtue of his office he possesses supreme, full, immediate, and universal ordinary power in the Church, which he is always able to exercise freely."); Sägmüller, supra note 408, at 568 (citing Matthew 18:15; 1 Corinthians 4:21, 5:1; 2 Corinthians 13:10; 1 Timothy 1:20, 5:19).

416. See 1983 CODE c.331; Ivor Roberts, Is the Holy See Above the Law?, TIMES (Apr. 13, 2010, 7:14 PM), https://www.thetimes.co.uk/article/is-the-holy-see-above-the-law-tq6xj31rctx [https://perma .cc/UM8R-YHP4].

417. See 1983 CODE cs.333, § 1, 334, 344 ("The synod of bishops is directly subject to the authority of the Roman Pontiff . ...”); Epistle (29) from Pope Innocent I to the African Bishops (Jan. 27, 417), reprinted in HENRY DENZINGER, THE SOURCES OF THE CATHOLIC DOGMA 44 (Roy J. Deferrari trans., 13th ed. 1955); Breve del Sommo Pontefice Pio VI: Super Soliditate Petrae [Brief from the Great Pontiff Pius VI: Over the Solid Rock] (Nov. 28, 1786), http://www.vatican.va/content/pius-vi/it/documents/ breve-super-soliditate-petrae-28-novembre-1786.html [https://perma.cc/7S9Z-Z59W]; Encyclical from Pope Leo XIII on the Unity of the Church: Satis Cognitum (June 29, 1896), http://www.vatican.va/content/leo-xiii/en/encyclicals/documents/hf_l-xiii_enc_29061896_satis-cognitu m.html [https://perma.cc/9L72-CHXN]; Encyclical from Pope Pius XII on the Mystical Body of Christ to Our Venerable Brethren, Patriarchs, Primates, Archbishops, Bishops, and Other Local Ordinaries: Mystici Corporis Christi (June 29, 1943), http://www.vatican.va/content/pius-xii/en/ 
bishops ${ }^{418}$ and no act of a college or council is valid until affirmed by the Pope ${ }^{419}$ The relationship between the Holy See and the clergy is sometimes considered collegial or autonomous, though it is not independent, and the Pope has the authority to determine what collegial means. ${ }^{420}$ This state of affairs between the Holy See and the clergy is not limited to the mere appointment of a person to an office, ${ }^{421}$ but demonstrates sufficient control to be a "significant and decisive influence ... by virtue of the ... political, financial and other support given to it" required by human rights law. ${ }^{422}$ As a simple observation, it is difficult to imagine the continuance of any clergy or related church activities if the Holy See refused to approve or terminated its support.

Secondly, the precise nature of the obedience as religious or otherwise, is not relevant, as human rights bodies have affirmed control through a variety of means, resting on de facto control. The Holy See cannot claim that clergy are free to act as they wish when all "power" is ultimately held by the Pope ${ }^{423}$ Even if obedience is due to religious conviction or understanding, if

encyclicals/documents/hf_p-xii_enc_29061943_mystici-corporis-christi.html [https://perma.cc/637NE8FY]; Joseph Hergenröther, 1 CATHOLIC CHURCH AND CHRISTIAN STATE: A SERIES OF ESSAYS ON THE RElAtion OF THE CHURCH TO THE Civil POWER 168 et seq. (1876); Fenton, supra note 413.

418. See Fenton, supra note 413.

419. See 1983 CODE cs.341, §§ 1-2, 449, § 1 .

420. See id. c.337, §§ 2-3; Lumen Gentium [Constitution] Nov. 21, 1964, Ch. 1, para. 22 (Vatican) ("But the college or body of bishops has no authority unless it is understood together with the Roman Pontiff, the successor of Peter as its head. The pope's power of primacy over all, both pastors and faithful, remains whole and intact. In virtue of his office, that is as Vicar of Christ and pastor of the whole Church, the Roman Pontiff has full, supreme and universal power over the Church. And he is always free to exercise this power. The order of bishops, which succeeds to the college of apostles and gives this apostolic body continued existence, is also the subject of supreme and full power over the universal Church, provided we understand this body together with its head the Roman Pontiff and never without this head. This power can be exercised only with the consent of the Roman Pontiff."); Holy See and the PRC, supra note 97 ("MSGR. ROTA-GRAZIOSI SAID THAT THE CATHOLIC CHURCH IN CHINA 'MUST BE AUTONOMOUS, BUT COULD NOT BE INDEPENDENT' FROM THE HOLY SEE. HE GAVE THE EXAMPLE OF THE CATHOLIC CHURCH IN THE U.S., WHICH WAS SELFGOVERNING BUT ACCEPTED GUIDANCE AND INTERVENTION FROM THE POPE.”).

421. See Drozd v. France, Appl. No. 12747/87, paras. 91-96 (Eur. Ct. H.R., 1992), http://hudoc.echr.coe.int/eng?i=001-57774 [https://perma.cc/79FU-QAJ2\#\{\%22itemid\%22:[\%22001$57774 \% 22]\}]$.

422. Chiragov v. Armenia, 2015-III Eur. Ct. H.R. 135, para. 186; see also Application of the Int'1 Convention on the Elimination of All Forms of Racial Discrimination (Geor. v. Russ.), 2008 I.C.J. 353, I 149 (Oct. 15); Ilașcu v. Moldova, 2004-VII Eur. Ct. H.R. 179, paras. 8, 392-94, 454; Issa v. Turkey, App. No. 31821/96, para. 74 (Eur. Ct. H.R., 2004), http://hudoc.echr.coe.int/eng?i=001-67460 [https://perma.cc/82GS-2F6Z]; Cyprus v. Turkey, 2001-IV Eur. Ct. H.R. at 1, paras. 77-78; Loizidou v. Turkey, 1996-VI Eur. Ct. H.R. 2217, paras. 52-56.

423. See 1983 CODE c.333, § 1 ("By virtue of his office, the Roman Pontiff not only possesses power over the universal Church but also obtains the primacy of ordinary power over all particular churches and groups of them."). 
representatives of the clergy comply with the command of the Holy See, then they are under de facto control.

Oddly, for its part, the Holy See has argued to the Committee on the Rights of the Child that churches, not Vatican organs, are responsible under canon law for discharging its international obligations under the CRC. ${ }^{424}$ The Holy See cites its own internal assignment of responsibility for compliance with the CRC by church organs. ${ }^{425}$ To avoid any doubt, the Holy See specifically argues that these entities are all Church, not Vatican City, organs. ${ }^{426}$ This argument suggests that the actions of churches would implicate the responsibility of the See. It also contradicts the Holy See's argument that it is only responsible for compliance with the CRC within the Vatican City.

\section{iii. Jurisdiction Based on Physical Control over the Victim}

Attribution is the first step. In addition to the actor being a state official or a person whose acts are attributable to the state, the person must exercise jurisdiction over the victim. This level of control can be physical. Cases include extraterritorial arrest or kidnappings, ${ }^{427}$ enforcement of border control prior to arrival at the border, ${ }^{428}$ military action overseas, ${ }^{429}$ and interdiction of ships on the high seas. ${ }^{430}$ So where a de jure state official, such as a police officer, acts abroad to physically control another person, the

424. See Second Reports of States Parties Due in 1997, supra note 16, I 57(b)-(e), (j)-(k) (submitting the worldwide work of the Pontifical Council for the Family (PCF), the Pontifical Council for Justice and Peace (PCJP), the Pontifical Council for the Laity (PCL), the Pontifical Council for the Pastoral Assistance to Health Care Workers (PCHCW), the Pontifical Council Cor Unum (Cor Unum), and the Pontifical Missionary Society of the Holy Childhood (Holy Childhood)); Initial Reports of States Parties Due in 1992, supra note 16, 91 19-23, 44-59.

425. See Second Reports of States Parties Due in 1997, supra note 16, 1 57; Initial Reports of States Parties Due in 1992, supra note 16, q9 19-23 (outlining the work of the Pope, Holy See bodies, international Catholic organizations, and bodies within the Catholic Church in implementing the Convention).

426. See Second Reports of States Parties Due in 1997, supra note 16, 157.

427. See Commc'n No. 52/1979, supra note 249, ๆ甲 12.1-.2; Commc'n No. 56/1979, supra note 305, Фণ 10.1-.2.

428. See X \& Y v. Switzerland, App. Nos. 7289/75 \& 7349/76, 9 Eur. Comm'n H.R. Dec. \& Rep. 57, 71-73 (1977).

429. See HRC, Obligation to Covenant, supra note 245, ๆๆ 3, 11; Comm. Against Torture, General Comment No. 2, supra note 329, -16; U.S. Military Activity in Panama, Case 10.573, Inter-Am. Comm'n. H.R., Report No. 31/93, OAE/Ser.L/V.85, doc. 9 rev. $9 \uparrow$ 6, 56-57 (1993); Al-Saadoon v. United Kingdom, App. No. 61498/08, paras. 85-89 (Eur. Ct. H.R., 2009), http://hudoc.echr.coe.int/eng?i=00193398 [https://perma.cc/NH2M-YHBT]; Al-Skeini v. United Kingdom, 2011-IV Eur. Ct. H.R. 99, paras. 132, 136; Al-Jedda v. United Kingdom, 2011-IV Eur. Ct. H.R. 305, paras. 85-86; Jaloud v. Netherlands, 2014-VI Eur. Ct. H.R. 229, paras. 140-53; Situation of Detainees at Guantanamo Bay, supra note 366.

430. See Medvedyev v. France, 2010-III Eur. Ct. H.R. 61, para. 67; Haitian Ctr. for Human Rights v. United States, Case 10.675, Inter-Am. Comm'n H.R., Report No. 51/96, OEA/Ser.L/V/II.95, doc. 7 rev. 171 (1997). 
human rights treaties would generally consider that the state exercised its jurisdiction. $^{431}$

In some cases, officials of the Holy See exercise physical control. The Holy See does have its own police and the famous Swiss Guard, that may operate extraterritorially, especially as security for the pope when travelling internationally. ${ }^{432}$ In the section on territorial control, we considered whether control over a school would amount to exerting control to satisfy jurisdiction. If that degree of control would not be sufficient to establish jurisdiction over the area generally, then we can alternatively consider that the control over a child as a victim would be sufficient. ${ }^{433}$ The law only requires a minimum degree of control over another person, as in the case with kidnapping, ${ }^{434}$ as noted above. Surely, the restraint exercised by an adult priest over a child for purposes of rape or other sexual abuse would amount to sufficient physical control under this test.

iv. Jurisdiction Based on Non-Physical Control over the Victim

However, other means of control over the victims can also amount to sufficient control, and thus jurisdiction. For example, diplomatic and consular personnel abroad can exercise jurisdiction by refusing to issue a passport to a national. ${ }^{435}$ The Human Rights Committee in Montero, as well as in other cases, has reasoned that the failure to issue a passport resulted in an infringement of the ability to travel internationally, and was thus a violation of the human right to leave any state, as provided in the ICCPR. ${ }^{436}$ The European Court of Human Rights in Assanidze suggested that it might take a more expansive approach, stating that extraterritorial jurisdiction exists for:

431. See Stocké v. Germany, 199 Eur. Ct. H.R. (ser. A) at 22-24, paras. 158-66 (1989); Chiragov v. Armenia, 2015-III Eur. Ct. H.R. 135, para. 186; Ilaşcu v. Moldova, 2004-VII Eur. Ct. H.R. 179, para. 8; Cyprus v. Turkey, 2001-IV Eur. Ct. H.R. paras. 77-78; Issa v. Turkey, App. No. 31821/96, para. 74 (Eur. Ct. H.R., 2004), http://hudoc.echr.coe.int/eng?i=001-67460 [https://perma.cc/82GS-2F6Z]; Loizidou v. Turkey, 1996-VI Eur. Ct. H.R. 2217, para. 56; Sánchez Ramirez v. France, App. No. 28780/95, 86-A Eur. Comm'n H.R. Dec. \& Rep. 155, 161-62 (1996); Comm. Against Torture, General Comment No. 2, supra note 329, ๆๆ 16, 18.

432. See DAVID Alvarez, The Pope's SOldiers: A Military History OF THE MODERn VATICAN 365 (2011).

433. See Second Reports of States Parties Due in 1997, supra note 16, 1 ฯ 32, 75 (reporting that the activities of Catholic schools and health care institutions are exercised under their "own authority and responsibility under canon law").

434. See supra notes 427, 431 and accompanying text; 1983 CODE cs.331; 1442.

435. See Assanidze v. Georgia, 2004-II Eur. Ct. H.R. 221, para. 137 ("[J]urisdiction is assumed on the basis of non-territorial factors, such as: acts of public authority performed abroad by diplomatic and consular representatives of the State ....”); Commc'n No. 106/1981, supra note 297, ๆ 5; Commc'n No. 1107/2002, supra note 369, ๆๆ 8, 10; Commc'n No. 108/1981, supra note 369, ๆ 6.1.

436. See ICCPR, supra note 235, art. 12(2); Commc'n No. 106/1981, supra note 297, ๆ 5. 
acts of public authority performed abroad by diplomatic and consular representatives of the State; the criminal activities of individuals overseas against the interests of the State or its nationals; acts performed on board vessels flying the State flag or on aircraft or spacecraft registered there; and particularly serious international crimes (universal jurisdiction). ${ }^{437}$

The Court did not require any human rights violation to be the object of control in order to establish jurisdiction. This statement by the Court has been implicitly affirmed subsequently as governing the interpretation of jurisdiction. ${ }^{438}$ That being said, human rights bodies do not yet appear willing to consider every and any act of a state extraterritorially as an exertion of control. ${ }^{439}$ It would seem that in order for an extraterritorial act to constitute control, there must be some additional coercive aspect to it. A possible compromise interpretation that does not accept the full scope of Assanidze but accommodates the approach of Montero and other cases, could be the interpretation that the state has jurisdiction only where the acts have a decisive impact on a person's freedom.

A few situations will be omitted in the interest of space. Aside from the insignificant number of Holy See nationals, no individual needs a passport from the Holy See. We will therefore omit a lengthy examination of this possibility and move to comparable assertions of control which constitute sufficient restrictions on individual liberty that rise to the level of jurisdiction. Similarly, we already considered the degree of control asserted over clergy, who could, in addition to serving as a state agent, also serve as a victim. The more problematic category is non-clergy victims.

The Holy See does assert some control over non-clergy, but the question is whether the degree of control is sufficient to establish jurisdiction over victims, and then responsibility for treating those persons in compliance with the CRC. The Holy See admits that it does exercise this jurisdiction concurrently with territorial states, ${ }^{440}$ although it has also long argued that it does not have political control over the faithful, only spiritual control. ${ }^{441}$ While its legal prohibitions include many "normal" criminal offenses, such

437. See Assanidze, 2004-II Eur. Ct. H.R. para. 137.

438. Id.; Ilaşcu v. Moldova, 2004-VII Eur. Ct. H.R. 179, para. 312.

439. See Assanidze, 2004-II Eur. Ct. H.R. at 279 (Loucaides, J., concurring); Ilaşcu, 2004-VII Eur. Ct. H.R. at 329-31 (Loucaides, J., dissenting in part).

440. List of Issues in Relation to the Second Periodic Report, supra note 9, 99.

441. See Holy See Would Welcome Continued Presidential Push for Greater Religious Freedom in China (Oct. 23, 2002, 3:02 PM), https://wikileaks.org/plusd/cables/02VATICAN5194_a.html [https://perma.cc/Y3SP-7PB2] ("TO BETTER UNDERSTAND THE NATURE OF THE SPECIFIC LINK BETWEEN CATHOLICS AND THE HOLY SEE... . CATHOLIC FAITHFUL DO NOT ALWAYS FOLLOW THE HOLY SEE'S POSITIONS ON INTERNATIONAL SOCIAL ISSUES AND THAT PAPAL AUTHORITY IS A SPIRITUAL, NOT POLITICAL, MATTER.”). 
as crimes against security, ${ }^{442}$ it also includes religious offenses, under which it does prosecute lay individuals. ${ }^{443}$ Although its penalties do not include physically coercive sanctions, they involve coercive religious penalties. ${ }^{44}$

The question is therefore whether coercive religious compliance measures amount to sufficient non-physical control over a victim, and thus jurisdiction. As a preliminary matter, in rare cases the Holy See can enforce its religious measures where the territorial state accepts decisions of the Holy See or renders support to its activities. ${ }^{445}$ Setting aside those unusual cases, there is no per se reason why religious control could not suffice. After all, as noted previously, the fatwa by Iran against Salman Rushdie was a coercive religious act. ${ }^{46}$ In that case, Iran had argued that the order had been issued as a religious command, not a legal one. ${ }^{44}$ The Committee concluded that the fact that it was issued by a religious authority did not alone render it incapable of resulting in a violation of human rights. ${ }^{448}$ Aside from Iran, no representative objected to this interpretation of the ICCPR. ${ }^{449}$ This view is correct, because the legal test is de facto control, and spiritual control might

442. 1983 CoDE c. $221, \S \S 1-2$; Apostolic Letter Issued Motu Proprio, supra note 129, para. 1(a); Second Reports of States Parties Due in 1997, supra note 16, ๆ 98(a).

443. See 1983 CODE c.221, §§ 1-2; Sägmüller, supra note 408.

444. See Second Reports of States Parties Due in 1997, supra note 16, - 98(e); List of Issues in Relation to the Second Periodic Report, supra note 9, ๆ 9; Sägmüller, supra note 408.

445. See Agreement Concerning Legal Matters, supra note 301; see Sägmüller, supra note 408.

446. See HRC Comments: Iran, supra 305, ๆ 9.

447. U.N., Human Rights Comm., 48th Sess., 1251st mtg. at 12, U.N. Doc. CCPR/C/SR.1251 (July 29, 1993) [hereinafter HRC, 1251st Meeting Summary Record] ("Turning to the subject of the fatwa on Mr. Salman Rushdie . . . the fatwa had been issued by the Iman Khomeini as a religious leader and not as a representative of the Government. Any action taken in response to that fatwa would accordingly be based on an individual's religious beliefs. The question which now required an answer was whether the subsequent statement by President Rafsanjani, reported in Time International on 24 May 1993, that the sentence imposed on Mr. Rushdie had been prescribed by Islamic law, meant that the Iranian Government had now endorsed the fatwa, or whether, recognizing its responsibilities under international law, it was prepared to take a firm stand against the fatwa.").

448. See also HRC Comments: Iran, supra note 305, I 9 ("The Committee also condemns the fact that a death sentence has been pronounced, without trial, in respect of a foreign writer, Mr. Salman Rushdie, for having produced a literary work and that general appeals have been made or condoned for its execution, even outside the territory of Iran. The fact that the sentence was the result of a fatwa issued by a religious authority does not exempt the State party from its obligation to ensure to all individuals the rights provided for under the Covenant, in particular its articles 6, 9, 14 and 19."); see also U.N. Human Rights Comm., General Comment No. 22 (48) (art. 18), ๆ 7, U.N. Doc. CCPR/C/21/Rev.1/Add.4 (Sept. 27,1993 ) ("According to article 20, no manifestation of religions or beliefs may amount to propaganda for war or advocacy of national, racial or religious hatred that constitutes incitement to discrimination, hostility or violence. As stated by the Committee in its General Comment 11, States parties are under the obligation to enact laws to prohibit such acts.") (citations omitted).

449. See HRC, 1251 st Meeting Summary Record, supra note 447; U.N. Human Rights Comm., 48th Sess., 1252nd mtg., U.N. Doc. CCPR/C/SR.1252 (June 27, 1994); U.N. Human Rights Comm., 48th Sess., 1253rd mtg., U.N. Doc. CCPR/C/SR.1253 (July 30, 1993); HRC Comments: Iran, supra note 305. 
be just as effective as political control or even physical control. The Holy See states that the faithful are bound by Canon law worldwide, and the Holy See globally exercises its criminal jurisdiction. ${ }^{450}$ Under the Canon law, Catholic lay faithful are "obliged" to assist the Church, ${ }^{451}$ and the Church has the right to make requirements of the faithful. ${ }^{452}$ It is certainly feasible that a religious obligation or punishment for a faithful person could be very coercive.

This kind of control presents some challenges. One difficulty is that the degree of control might vary depending on the degree of religious conviction. In the physical and non-physical examples mentioned above, such as diplomatic or consular control, the degree of control was constant from person to person. That might not always be the case for the degree of control over the right to leave any state by refusing a passport would vary from person to person depending on the person's desire to leave the state. In any event, the same reasoning might apply in physical control cases, as the degree of control might vary depending on whether the person wanted to leave physical control, and we do not test the subjective experience of control. One way forward is to consider that the refusal of the passport was not only explained as an infringement of an ICCPR right, but the assertion of authority and the restriction over the liberty of a person. Similarly, religious commands can restrict the freedom of the faithful.

The practice of the Holy See under the CRC already hints that this is the correct interpretation. In its compliance reports to the Committee on the Rights of the Child, the Holy See repeatedly submitted the evidence of church practices, ${ }^{453}$ as evidence of its compliance with the CRC. ${ }^{454}$ In particular, the Holy See cited its pastoral guidelines for social work, ${ }^{455}$

450. See Second Reports of States Parties Due in 1997, supra note 16, I 98(a) ("Penal canon law addresses disturbances to the public order of the Church, it therefore, briefly treats the subject matter of delicts (e.g. homicide, theft, aggression, and sexual abuse) . ...").

451. See 1983 CODE cs.221-22, § 1 .

452. See id. at c. 1260 .

453. The Holy See has not previously objected citing to church teaching, policy, and practice as evidence of compliance, see, e.g., CERD Report 1993, supra note 347, \ 291; CERD, Consideration of Reports 2000, supra note 23, १ฯ 7-8; CERD, Consideration of Reports 2001, supra note 347; List of Issues in Relation to the Second Periodic Report, supra note 9; CERD, Consideration of Reports 2014, supra note 17, ๆ 44; CERD, Concluding Observations 2016, supra note 145, ๆ $4,8$.

454. See Second Reports of States Parties Due in 1997, supra note 16, ๆף 26, 49, 50-52, 57(b), 57(f), 57(i), 64(b), 65(c)-(d), 68(b), 73, 99(a), 99(e); Initial Reports of States Parties Due in 1992, supra note 16 , $194,7,16(\mathrm{a})$.

455. See Second Reports of States Parties Due in 1997, supra note 16, ๆๆ 64(c), 90, 101, 103. 
training and ministering, ${ }^{456}$ and even its teaching, ${ }^{457}$ citing the Bible itself, as evidence of CRC compliance. ${ }^{458}$ If only political activities would result in effective control, then why are religious activities relevant for compliance with international law? While the Holy See may take the position that these activities fall under its non-binding duty to encourage compliance with the $\mathrm{CRC},{ }^{459}$ the Holy See has used this information to prove that it respects and ensures legal compliance. In any event, there is no provision in the CRC for encouragement. It seems odd that a party would identify its extraterritorial practice as evidence of compliance if those activities were not having a significant impact on persons abroad. Indeed, the Holy See has claimed that its doctrine has a significant impact on the treatment of persons in foreign territories. $^{460}$

\section{CONCLUSION}

This article has assessed whether the Holy See is bound to comply with the CRC for its worldwide activities, not only its governance of the Vatican City. Firstly, the article considered whether the Holy See or Vatican City was the party to the CRC and incurred obligations. International law is clear that the Holy See and Vatican are separate legal persons, and the Holy See affirms this. The best view is that the Holy See is the sovereign (or perhaps government) of the Vatican City, while simultaneously being the government of the Catholic Church. Because the Holy See and Vatican are distinct, the Holy See also exercises distinct and separate treaty-making capacity through the personality of itself or the Vatican City, as appropriate. In adhering to the CRC, the Holy See acted on its own behalf, but not of the Vatican City. It has also affirmed this practice and its understanding that it is the party in all subsequent communications with the Committee on the

456. See List of Issues in Relation to the Second Periodic Report, supra note 9, $₫$ \ 22, 24.

457. See CERD, Consideration of Reports 2014, supra note 17, ๆ 46 (quoting Pope John Paul II, Angelus (Aug. 26, 2001)) (citing Pope Paul VI, Declaration on the Relation of the Church to NonChristian Religions (Oct. 28, 1965)) ("Racism is a Sin, a Serious Offense Against God: In 2001, Pope John Paul II stated: 'Every upright conscience cannot but decisively condemn any racism, no matter in what heart or place it is found. Racism is a sin that constitutes a serious offence against God."'); CERD Report 1993, supra note 347, ๆ $279-80$; CERD, Consideration of Reports 2014, supra note 17, ๆ 45 ("[T]he elimination of racial discrimination is sought in multiple areas by proclaiming the dignity of the human person according to the teachings of Jesus Christ.").

458. See Second Reports of States Parties Due in 1997, supra note 16, 98(f); List of Issues in Relation to the Second Periodic Report, supra note 9, 97 (citing Letter from Pope John Paul II to the Bishops, Priests, Deacons, Men and Women Religious, Lay Faithful, and all People of Good Will on the Value and Inviolability of Human Life: Evangelium Vitae (Mar. 25, 1995), http:/www.vatican.va/ content/john-paul-ii/en/encyclicals/documents/hf_jp-ii_enc_25031995_evangelium-vitae.html [https:// perma.cc/39FJ-QMLQ] (citing Leviathan 19:18).

459. Second Reports of States Parties Due in 1997, supra note 16, ๆ 38.

460. See List of Issues in Relation to the Second Periodic Report, supra note 9, $₫ 26$. 
Rights of the Child. All of the parties to the CRC have affirmed or acquiesced to this practice. Therefore, the Holy See is the party, not the Vatican City.

In adhering to the $\mathrm{CRC}$, the scope of its application was not limited in any significant way. The CRC contains no terms unique to the Holy See. The Holy See did enter a reservation seeking to limit the scope of the treaty. However, its terms only applied to the "particular nature of the Vatican City" and its laws on "citizenship, access and residence." declaration stating that its participation in the $\mathrm{CRC}$ did not intend to "prescind" from its "specific mission which is of a religious and moral character." 462 This declaration, by its non-binding nature, does not attempt to alter the legal scope of the CRC. These actions mean that all of the Holy See's worldwide activities are subject to compliance with the CRC. For those worldwide activities regarding the governance of the Vatican City, the CRC does not impose obligations concerning "citizenship, access and residence" practice of law.

Having established that the Holy See is bound to comply with the CRC in its worldwide activities, the article then considered whether the Holy See exerts control sufficient to trigger the application of the CRC. Human rights law does not apply to all of the activities of a state. It only applies in the state's territory and/or where the state has "jurisdiction." The precise scope of application varies from treaty to treaty, but a rather consistent jurisprudence has developed for the meanings of territory and jurisdiction. The CRC only applies where a state has "jurisdiction." States are understood to have jurisdiction in their territory or in areas beyond their territory where they exercise de facto effective control.

The last substantive part of the article considered the situations in which the Holy See would have sufficient control to acquire jurisdiction, and then responsibility for ensuring human rights in the CRC. The Holy See, of course, has no territory, so all analysis of its control is tested as extraterritorial control. It does exercise an effective, de facto, physical control over the Vatican City State. It also exercises de facto, physical control over certain extraterritorial places such as embassies, churches, religious sites, and Castel Gandolfo. In some schools, notably where the Holy See acts in loco parentis, it might also have sufficient control to acquire jurisdiction.

In addition to the extraterritorial control over a place, the Holy See also exercises control over persons. Certainly, in situations where the actor is a

461. Convention on the Rights of the Child, supra note 1, at 176; Status of the CRC, supra note 3.

462. Convention on the Rights of the Child, supra note 1, at 176; Status of the CRC, supra note 3; List of Issues in Relation to the Second Periodic Report, supra note 9, १ๆ 6-7. 
state agent, the Holy See has control. It might also have control over nondiplomatic clergy when those individuals benefit from a quasi-diplomatic status or have privileges and immunities pursuant to concordats or local law. Furthermore, it could also have control over other non-diplomatic clergy and other church actors when those actors are controlled through religious obligations, where the Holy See retains exclusive power, recognized by the territorial state, to appoint, supervise, and discipline. Where any of these actors assert control over a victim, the Holy See will be exercising jurisdiction. It could be that the control is physical, where security officers operate abroad, or a clergy member physically dominates a person. The control over a victim might also be religious. Human rights law does not limit control over a victim to only physical restriction, but also other limitations regarding freedom of movement and action. The test is not whether the restriction is political, legal, or otherwise. The test is only de facto control. Religious obligations and commands that induce compliance with restrictions on the part of non-clergy may also constitute sufficient control under this test.

Based on the foregoing, the CRC applies to the worldwide activities of the Holy See, where it exercises sufficient control over persons and places, including, but not limited to, its governance of the Vatican City. It may sound odd at first glance that a church would need to comply with international law in its governance and operations. After all, freedom of religion is a fundamental human right. However, when a church's governing body moves into the political sphere, it acquires international legal personality, and uses that personality to adhere to international law. As such, its government incurs binding international legal obligations and it can no longer invoke religious freedom as if it was solely a religious actor. Although the tenets of its faith are not bound to international law, the acts of its governing body must now comply with the law. It is the price of international legal personality and participation in international law. Such an entity is always free to disclaim this personality or refuse to participate in international law-making. By adhering to international law, complying with international law, and accepting responsibility for violations of international law, the Holy See affirms its international legal personality. 